\title{
Eduardo Sanovicz
}

A Promoção Comercial do Turismo Brasileiro no Exterior:

O caso da reconstituição da Embratur

Tese apresentada ao Departamento de Publicidade, Relações Públicas e Turismo da Escola de Comunicações e Artes da Universidade de São Paulo, para a obtenção do título de Doutor.

Turismo.

Orientador: Professor Doutor Mario Carlos Beni 


\section{AGRADECIMENTOS}

A Bete, por ter compreendido, apoiado e mais ainda, cuidado de tudo e de todos nós durante um período longo e difícil. Não há prova de amor maior que essa.

A Mari, Carol, Gabi e Artur, por serem, no fundo, a razão de todo este esforço, meu e de muitos como eu, na construção de um outro mundo, justo, solidário e fraterno.

A minha mãe e a meus irmãos, testemunhas vivas da herança cultural de meu pai, Prof. Dr. Abrahão Sanovicz, Livre-Docente da Universidade de São Paulo, cuja memória e história me trouxeram até aqui

A todos os meus companheiros desta viagem, por Santos, Barcelona, São Paulo, Brasília, e por uma vasta parte deste planeta azul, por terem compartilhado tempo e energia, compromisso com resultados e disposição de luta na construção de um novo paradigma para o turismo brasileiro. Como chamamos o turismo de atividade da paz, vocês sim, que a cada dia teceram com paciência, alguns entre os melhores exemplos de promoção turística que este país conhece, são "os turistas de guerra" de que fala a música.

Aos mestres que, mais ainda do que me orientarem, compartilharam comigo desta experiência, em especial ao Prof. Dr. Mario Carlos Beni.

Aos que lideraram e conduziram as organizações em que exerci as atividades que me permitiram construir esta história: a Davi Capistrano da Costa Filho, Carlos Lamberti, Raimon Martinez Fraile, Pere Duran, Airy Garrigosa, Ignasi de Delas i Ugarte, Roberto Gheler, Aristides Cury, Marta Suplicy, Rui Falcão, Walfrido dos Mares Guia e Luiz Inácio Lula da Silva 
CoM CARINHO ESPECIAL, A tOdOS AQUELES QUE CONSTRUíRAM E, APAIXONADAMENTE, FIZERAM PARTE DA “ALDEIA GAULESA”, UNIDA, IRREDUTíVEL E INVENCÍVEL....

A IMAGEM ABAIXO, É NOSSO LEGADO E NOSSA HISTÓRIA.

Os estrangeiros levaram muitas lembranças do Brasil em 2006. Em compensação, deixaram 4,316 bilhões de dólares.

0 turismo brasileiro acaba de bater mais um recorde: a entrada de US\$ 4,316 bilhres em 2006. Crescimento que traduz a atençăo aos turistas estrangeiros e os investimentos do Ministério do Turismo, por meio da Embratur, para a melhoria da imagem do Brasil. É investimento com o retorno para a economia do país, gerando renda e mais empregos. E quando o turismo cresce, todo o Brasil cresce junto.

www.braziltour.com

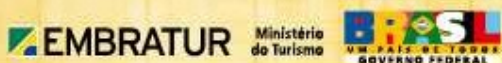

US\$ 4,316 bilnס̃es

2006

US\$ 3,861 bilhøes 2005

US\$ 3,222 bilhres 2004

US\$ 2,479 bilhres 2003

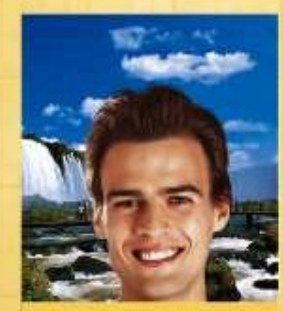

Toni Cebrian. Espanha

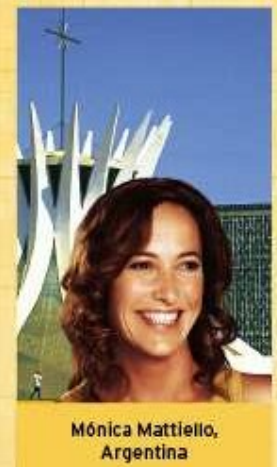

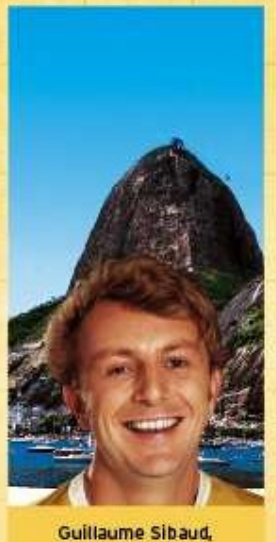

França

\section{BRASIL}

Sensacional!

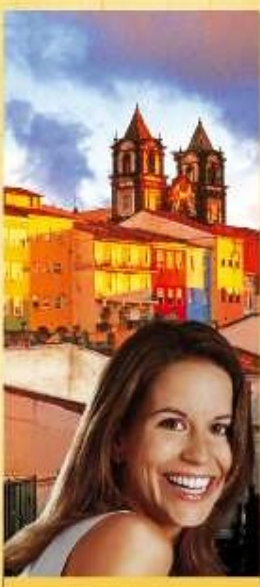

Dominique Benz, Estados Unidos 


\section{LISTA DE ILUSTRAÇÕES}

Diagrama 1 - Alinhamento Estratégico e Definição da Estrutura Organizacional .............. 27

Foto 1 - Pré-Plano Aquarela: Estande no Brasil na Feira BIT ............................................41

Foto 2 - Pós-Plano Aquarela: Estande do Brasil na Fitur .....................................................41

Foto 3 - Apoio à Captação de Eventos Internacionais 2006 ..........................................49

Foto 4 - Apoio à Promoção de Eventos Internacionais - 2006 ................................................ 49

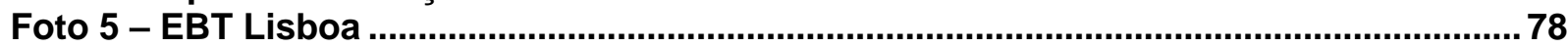

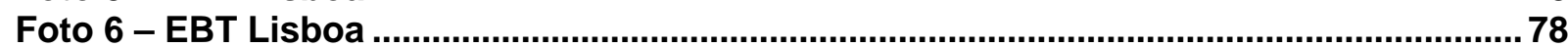

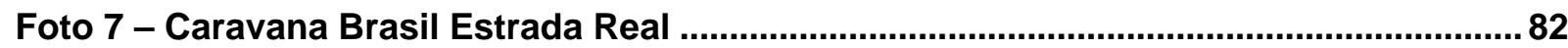

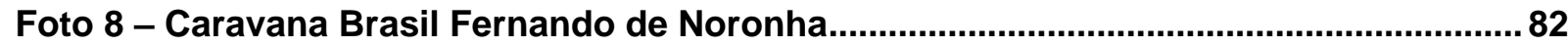

Foto 9 - Reunião do Programa de Visitas Técnicas, em Brasília .........................................89

Foto 10 - Ação de Promoção de Competição Internacional de Vela em 2006....................101

Figura 1 - Site do Programa "Agenda de Promoção Comercial do Turismo Brasileiro no Mercado Internacional"

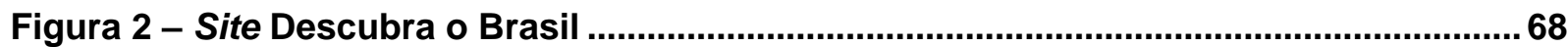

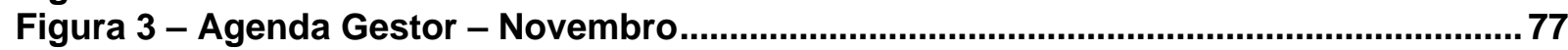

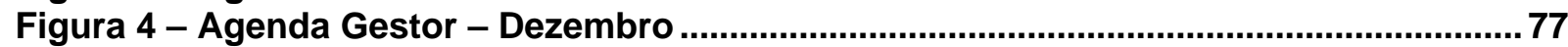

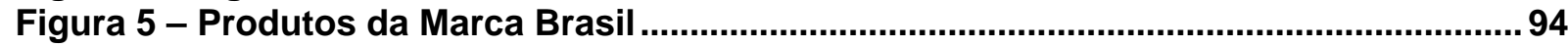

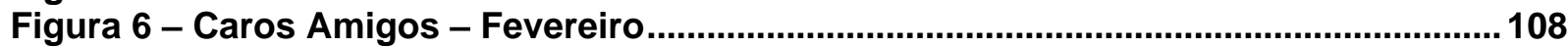

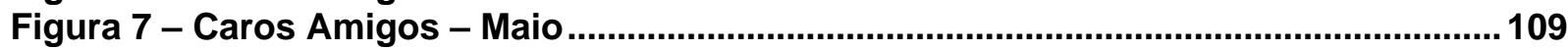

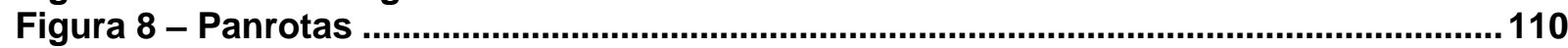

Gráfico 1 - Crescimento do Mercado Internacional do Turismo após a Segunda Guerra

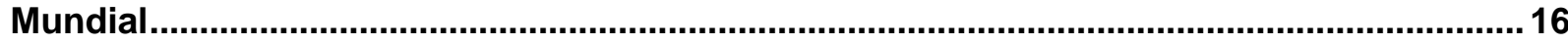

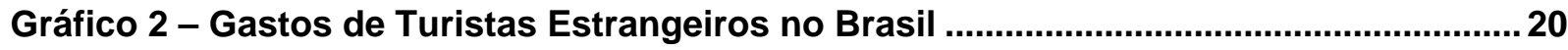

Mapa 1 - Pontos de Coleta de Dados …........................................................................116

Quadro 1 - Participação nas Feiras Internacionais de Turismo............................................44

Quadro 2 - Resumo de Ações e Resultados dos Bureaux de Comercialização ..................60

Quadro 3 - Dados dos Seminários Descubra o Brasil.......................................................63

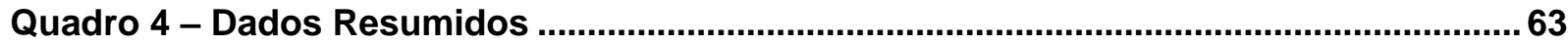

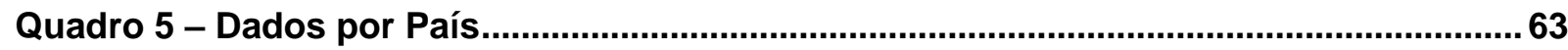

Quadro 6 - Estrutura de Funcionamento de Concorrentes Turísticos Internacionais........74

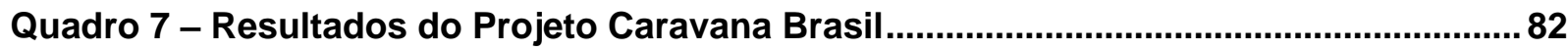

Quadro 8 - Evolução das Amostras a partir de 2000 .......................................................113

Quadro 9 - Etapas da Pesquisa e Meses Correspondentes ..............................................117 


\section{LISTA DE TABELAS}

Tabela 1 - Pesquisa de Opinião: Atualização Mercadológica 83

Tabela 2 - Pesquisa de Opinião: Avaliação dos Destinos Visitados - Comercialização ... 83 Tabela 3 - Pesquisa de Opinião: Sugestões de Melhorias para a Comercialização do Turismo Brasileiro 


\section{SUMÁRIO}

APRESENTAÇÃO........................................................................................... 8

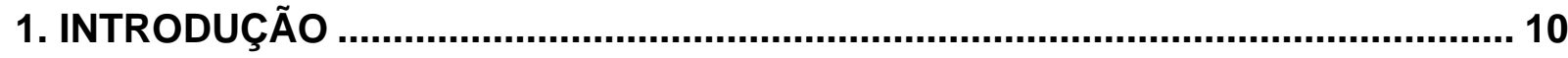

2. PROMOÇÃO COMERCIAL .............................................................................. 36

2.1 Programa DE FEIRAS INTERNACIONAIS DE TURISMO .......................................... 36

2.1.1 As dimensões das feiras internacionais.................................................. 42

2.2 Política de Apoio À CAPTAÇÃo, Promoção e Realização de Eventos

INTERNACIONAIS ....................................................................................................... 44

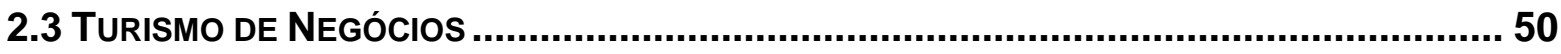

3. APOIO À COMERCIALIZAÇÃO ..................................................................... 58

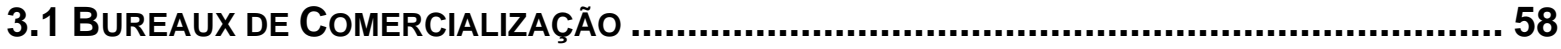

3.2 Seminários Descubra o Brasil, Treinamento de Agentes de Viagens e Apoio a

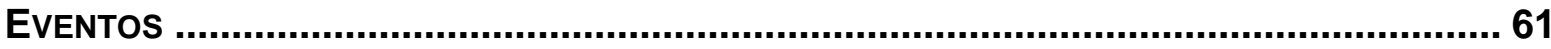

3.2.1 Seminário Descubra o Brasil .................................................................... 61

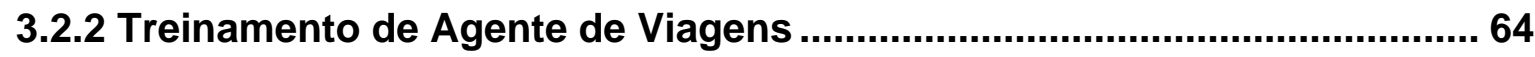

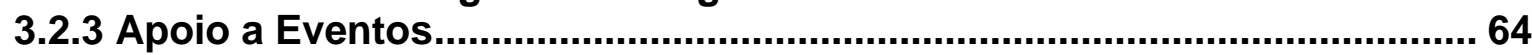

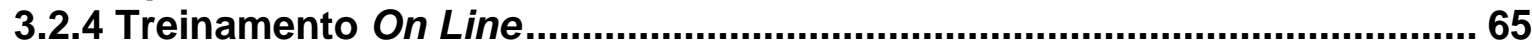

3.3 Projeto ExCELÊNCIA EM TURISMO: APRENDENDO COM AS MELHORES EXPERIÊNCIAS

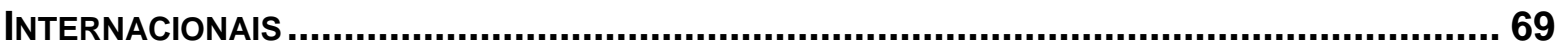

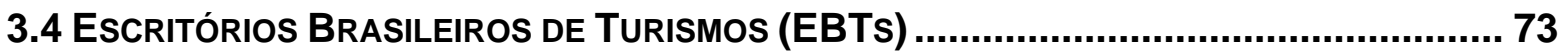

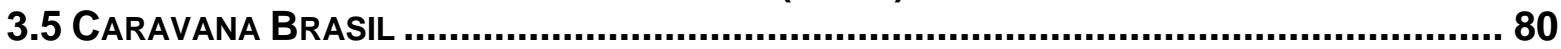

3.6 PROGRAMA DE VISITAS TÉCNICAS..................................................................... 87

4. COMUNICAÇÃO E MARKETING .................................................................. 91

4.1 Plano Aquarela - Marketing Turístico InTERnacional do Brasil .................... 91

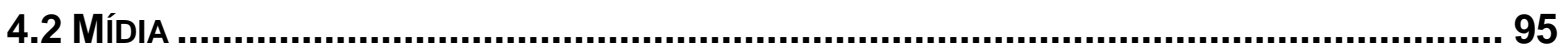

4.3 Brasil Network - Programa de Relacionamento do Turismo Brasileiro....... 98

4.4 Programa de RELAÇÕes PÚBLICAS ............................................................ 100

4.5 Programas dA ASSESSORIA de CoMUnICAÇÃo ................................................. 104

5. ESTUDOS E PESQUISAS ................................................................................. 110

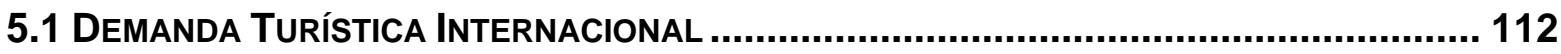

5.2 BOLETIM DE DESEMPENHO ECONÔMICO DO TURISMO ............................................ 119

5.3 PESquisa ANUAL de ConJUnTURA EconôMICA do TURISMo ................................ 120

5.4 Pesquisa - MeIOS de HospedaGem/EstrutuRA de Consumo e ImpaCtos NA

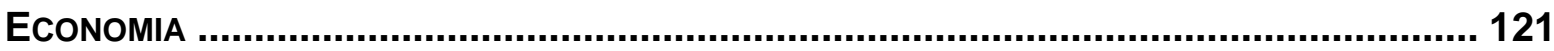

5.5 ESTUDO SOBRE ECONOMIA DO TURISMO: ANÁLISE DAS ATIVIDADES CARACTERÍSTICAS

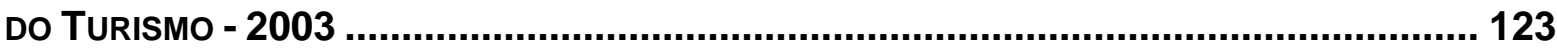

5.6 INDICADORES SOBRE MÃO DE OBRA FORMAL OCUPADA EM ATIVIDADES

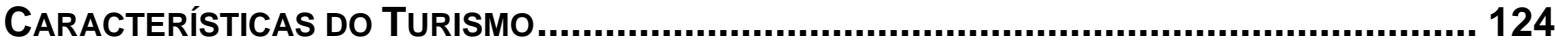

5.7 AÇões PARA O PROJETO dE ELABORAÇÃo dA CONTA SATÉLITE dE TURISMO NO BRASIL 
5.8 Prêmio de monografias e Mtur/Embratur/FGV de estudos de CASO E REPORTAGENS DO SETOR DE TURISMO E HOTELARIA.

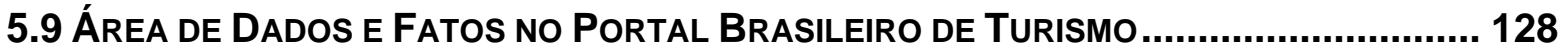

6. UM NOVO MODELO DE GESTÃO................................................................ 131

6.1 Novo Modelo de GeStÃo E A GESTÃo do CoNHECIMENTO................................... 131

6.2 O PROJETO do Novo MOdELO dE GESTÃo........................................................ 134

7. CONCLUSÃO: EQUIPE, CENÁRIO INSTITUCIONAL E PROJETO DE FUTURO 144

7.1 A QUALIDADE DA EQUIPE, A EMOÇÃO PRESENTE E MUITA CLAREZA POLÍTICA .............. 144

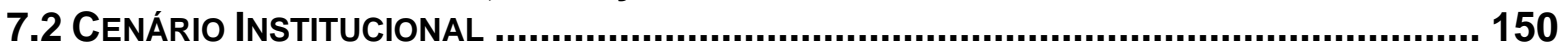

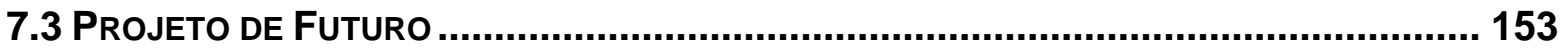

REFERÊNCIAS BIBLIOGRÁFICAS .............................................................. 155

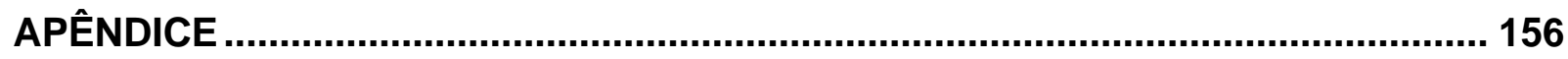

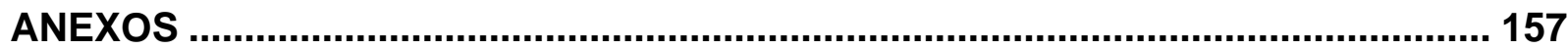




\section{APRESENTAÇÃO}

Durante a campanha eleitoral de 2002, o então candidato Luiz Inácio Lula da Silva assumiu com o setor do turismo, no Congresso da Associação Brasileira dos Agentes de Viagem (Abav), realizado em Recife, dois compromissos, atendendo reivindicações históricas do setor, a saber, a criação do Ministério do Turismo (Mtur), e a profissionalização da Empresa Brasileira de Turismo, atual Instituto Brasileiro de Turismo (Embratur). Ambos os temas eram objeto de debate desde o início dos anos 1990, não apenas nos sucessivos Congressos que a mesma Abav vinha realizando anualmente, mas em inúmeros outros eventos do setor. Na realidade, desde os anos 1980, quando as atividades ligadas tanto direta quanto indiretamente ao turismo passam a ter desempenho econômico importante nas contas nacionais de vários países, diversos segmentos questionavam as razões pelas quais o Brasil não avançava neste tema. Esta discussão, em decorrência da história de formação econômica do país, que determina um protagonismo fortíssimo do governo federal e de seu orçamento em praticamente todos os setores de atividade e em praticamente todas as regiões, acaba por apontar (de maneira até um pouco exagerada) a Embratur como principal responsável por uma mudança no setor, qual seja, aponta pra o mais tradicional instrumento federal de ação no turismo, um papel relevante e de vanguarda. Vale notar aqui que se repete uma tradição na história deste país: a burguesia nacional, novamente, em mais um setor, não assume papel de liderança em defesa de seus interesses, transferindo esta responsabilidade para o aparelho de Estado.

Ora, desde sua fundação em 1966, a Embratur desempenhou vários e distintos papéis na história econômica do país. Alguns com grande sucesso, como a implantação das linhas de financiamento no Nordeste (o Programa de Desenvolvimento do Turismo no Nordeste - Prodetur), outras com razoável sucesso, como a sustentação financeira de atividades turísticas e culturais em dezenas de estados e municípios, e um deles, infelizmente, com pouquíssimo sucesso: a promoção comercial do turismo brasileiro no exterior.

Ao início de 2003, o já Presidente Lula cumpre ambos os compromissos - é 
criado o Mtur, que passa a ter duas Secretarias Nacionais responsáveis por formulação e implementação das políticas públicas federais de turismo - e, por conseqüência, surge uma oportunidade inédita para a economia brasileira: a de criar uma unidade federal de promoção, apoio à comercialização e marketing de produtos, serviços e destinos turísticos brasileiros no exterior. Era a profissionalização da Embratur. Este trabalho se propõe a descrever, analisar e refletir criticamente sobre esta experiência e seus resultados. 


\section{INTRODUÇÃO}

Antes de analisar o desenvolvimento da promoção do turismo brasileiro nos últimos 25 anos, vale registrar aqui um episódio histórico, ocorrido em 1550, que ilustra como o Brasil, já naquela época, passados 50 anos apenas da chegada dos portugueses e outros europeus, começa a ser visto - e representado - como um país exótico, onde seus habitantes vestiam poucas roupas, quando não estavam completamente nus. No site de obras raras da Divisão de Bibliotecas e Documentação da Pontifícia Universidade Católica do Rio de Janeiro (PUC-Rio), podemos conhecer uma imagem significativa do Brasil no exterior, através do evento descrito pelo francês Ferdinand Denis, que visitou o Brasil entre 1816 e 1821, em seu livro Une Fête Brésilienne, publicado em 1850. Segundo o referido site, o livro descreve o seguinte evento:

No dia $1^{\circ}$ de outubro de 1550 , a cidade de Rouen, capital da província normanda, ofereceu uma "fête brésilienne" ao rei da França Henrique II e à sua mulher, Catarina de Médici. Fabricantes de tecidos e comerciantes de pau-brasil pretendiam convencer os soberanos a fundar uma colônia nas terras americanas pertencentes a Portugal. Às margens do Sena, foram construídas algumas aldeias indígenas, povoadas por trezentos índios tupis, dos quais somente uns cinqüenta eram autênticos. Os demais eram marinheiros normandos, freqüentadores do litoral brasileiro, e prostitutas, todos despidos para a encenação da vida tupinambá: cozinhavam, fumavam tabaco, deitavam em redes, caçavam e travavam batalhas.

Ironicamente, portanto, aquele momento, que pode ser considerado "a primeira ação de promoção do Brasil no exterior", foi demarcado por atitudes que, até bem recentemente, não apenas habitavam o imaginário dos estrangeiros que vêm ou pensam em vir ao país, mas também, lamentavelmente, constavam da agenda de atividades promocionais de vários agentes econômicos públicos e privados brasileiros, ao apresentarem-se no exterior.

Analisado a partir de meados da década de 1980, o turismo brasileiro que chega ao século XXI (concebendo nossa reflexão sempre tendo como foco o turismo enquanto atividade econômica) tem dois aspectos positivos e um negativo: 
- Quanto à infra-estrutura de equipamentos e serviços, tanto públicos quanto privados, chegamos a 2007 em posição bem melhor do que a que atravessávamos em 1987;

- Quanto à qualidade e à capacitação dos recursos humanos no setor, a avaliação positiva é a mesma;

- No entanto, não contamos a ninguém, no exterior, de forma gerencialmente organizada e comercialmente consistente, que havíamos cumprido com duas etapas importantes de nossa caminhada.

Qual seja, como dizemos em tom de chiste no cotidiano do mercado: ...ao norte do planeta, muitos ainda acham que, ao norte da Marquês de Sapucaí, só tem dragão cuspindo fogo... esta blague era um fato em janeiro de 2003.

Era exatamente este fato, compreendido pelos resultados pouco expressivos do turismo receptivo internacional no Brasil ao longo destas últimas duas décadas, que nos propusemos a enfrentar, construindo, a partir da velha autarquia, desenhada para atuar em controle, fiscalização e concessão de subsídios, uma unidade de promoção comercial do turismo brasileiro no exterior, cuja atuação fosse matizada tanto pela implementação de programas consistentes em relacionamento constante com os agentes econômicos do setor, como aferida por indicadores de resultado incontestáveis, tanto pelo mercado como pela sociedade.

É necessário, para compreender o que significa alterar estrutura, foco e programas, portanto investimento federal, ter em mente que a história econômica do Brasil criou um país no qual, com exceção da algumas poucas regiões metropolitanas, a atividade econômica é sempre iniciada após o investimento gerado pelo orçamento da União. Na maior parte do território nacional, e na grande maioria dos setores, só após o início da execução orçamentária federal é que o capital privado atua. Este fato, percebido e analisado por dezenas de historiadores ao longo dos séculos, tem reflexos em todos os setores de atividade econômica.

A prática de apropriação do aparelho de Estado por setores da classe dominante, tanto a nível federal como regional e local, determinando a quais setores internamente a esta mesma classe, se destinariam quais unidades da estrutura de estado e seus instrumentos, perpetuada ao longo de séculos, criou um país com 
praticamente nenhuma capacidade de iniciativa econômica local e uma restrita capacidade regional, concentrando a nível federal, um volume quase hegemônico de recursos. Esta estruturação da economia brasileira perpetuou um sistema de dominação político-econômico de um conjunto de oligarquias, articuladas entre si, que não sofre abalos sensíveis desde a implantação da república, com breves intervalos em parte do Período Vargas e durante a presidência Goulart. A razão do pânico instalado em amplos setores vinculados a estas oligarquias, verbalizados por seus porta-vozes na mídia, com o rompimento que representaria o Governo Lula, está exatamente no fato de que poderia se verificar a razão pela qual estes segmentos haviam desenhado e estruturado o Estado brasileiro: perdiam pela primeira vez o controle de classe social, em relação às prioridades e destinos dos recursos e investimentos federais, não seriam os seus herdeiros e associados os gestores que definiriam este destino. Entre todas as avaliações que se faziam naquele momento, o que não passava pela cabeça de ninguém, era que, entre todas as decisões a respeito de novos modelos de desenvolvimento, buscando opções para o Brasil que contemplassem inclusão social, respeito a valores culturais e meio ambiente, interiorização, resgate de auto estima, forte geração de empregos, prática cotidiana de mercado não monopolista, e finalmente, reinserção global do país, estivesse uma aposta de investir em turismo, particularmente em promoção e marketing do turismo brasileiro no exterior.

Outro parâmetro importante de inovação e ruptura, é mister registrar, é a inserção do segmento Negócios e Eventos na agenda do turismo brasileiro. A história de nosso setor, em especial a que é protagonizada pela Embratur, é marcada pelo binômio recursos naturais e lazer, qual seja, sol, praia, férias e temporada. Este eixo, que teve seu momento, não neguemos o fato, deixa de ser vetor de crescimento e protagonismo para um destino turístico, na mais otimista hipótese, em meados dos anos 1980. Embora o Brasil tenha começado a gerar Convention \& Visitors Bureaux (CVB) em novembro de 1983, com a criação do São Paulo CVB, chegamos a 2003, passados 20 anos, com a Embratur seguindo no relacionamento com o mercado como nos anos 1970 - propondo protagonismo aos agentes de viagem, com a secundarização dos demais segmentos, e ignorando em seus programas de trabalho as possibilidades geradas pelo turismo movimentado por razões de não-lazer. 
Portanto, quando o Governo Lula cria o Mtur, o que está apontando para o mercado e para a sociedade é uma mensagem de redirecionamento econômico: depois do eixo agrícola, com quase cinco séculos, e do eixo industrial, com quase dois séculos, há um terceiro eixo de investimento e desenvolvimento neste país - o de serviços -, e nele, as atividades ligadas direta e indiretamente ao turismo terão outra envergadura.

Cercados de ceticismo, iniciamos o ano de 2003 sob estas consignas, redesenhando completamente um modelo que perdurava há quase quatro décadas, apostando que três dados - o volume de dólares que ingressaria no país com turismo estrangeiro, o volume de chegadas internacionais de vôos regulares e charter e finalmente, o volume de entrada de turistas estrangeiros - nos dariam razão, ao final de quatro anos.

O novo papel do Governo como indutor do desenvolvimento desse segmento econômico foi debatido e apresentado à sociedade através do Plano Nacional de Turismo (PNT) 2003 - 2007, lançado no dia 29 de abril de 2003, em solenidade no Palácio do Planalto.

Do ponto de vista da agenda internacional, o ano de 2003 foi pautado:

1. pela reestruturação organizacional da Embratur;

2. pela formulação e implementação das novas estratégias;

3. pela divulgação dos compromissos e metas, que a partir de então passam a ser finalmente, e isto era inédito, quantificáveis e mensuráveis; e

4. pelo estabelecimento das parcerias estratégicas necessárias ao processo de mudança.

Além disso, em 2003 o foco foi voltado para rapidamente implantar as duas grandes novidades conceituais em termos da história de promoção comercial do turismo brasileiro:

1. a criação da Diretoria de Turismo de Negócios e Eventos da Embratur (com o conseqüente lançamento dos programas relacionados a captação de eventos internacionais, a revisão completa e posterior ampliação do programa de feiras, e o início do relacionamento do órgão federal com o setor de feiras de negócios); e 
2. a inserção dos CVBs como agentes protagonistas deste processo. Aqui devemos registrar que, ao contrário dos modelos praticados tradicionalmente na Europa e nos Estados Unidos, em geral entidades subvencionadas (e controladas) por recursos públicos, os CVBs brasileiros, a partir das unidades de São Paulo e Rio de Janeiro as primeiras a serem fundadas - são entidades privadas sem fins lucrativos.

Estas duas mudanças alteram por completo o eixo protagonista da promoção brasileira - no passado, tendo organizações ligadas apenas ao segmento de agências de viagens como parceiras, este país sustentou suas ações focado no segmento lazer e de forma que não permitia a inclusão participativa de outros setores, os quais, tendo como exemplo a hotelaria, profissionalizaram-se e inseriram-se no mundo global de maneira muito acelerada a partir da segunda metade da década de 1990. Ao não atuar no segmento negócios e eventos, e ao não inserir o receptivo organizado em cada destino, representado pelos CVBs, em sua estratégia ao longo dos anos 1980 e 1990, o Brasil que começa o século XXI estava profundamente atrasado em relação à concorrência. A favor dos gestores daquele período, destaque-se, no entanto, em formação de imagem internacional, o lançamento de uma campanha massiva de combate ao turismo sexual.

O ano de 2004 foi dedicado ao aprofundamento e consolidação das ações voltadas para a implantação e o desenvolvimento da área de Lazer e Incentivos. Ao contrário do segmento anterior, o país já desfrutava de larga experiência e estrutura neste segmento, cabendo-nos ações voltadas a ampliar os canais de distribuição de produtos e serviços, a ampliar o volume de produtos à disposição do mercado, tanto quanto ao número de destinos como quanto à diversidade de segmentos, assim como estabelecer um novo programa de relacionamento entre estes produtos e os mercados consumidores.

Destaque-se aqui, uma menção a este último item, cuja tradução concreta foi a criação dos Escritórios Brasileiros de Turismo (EBTs), tão polêmicos ao seu início, tendo acabado por consagrarem-se como uma das melhores práticas de gestão pública, sendo premiados, ao final de 2006, no 11ํㅡ Concurso Inovação na Gestão Pública Federal, promovido pela Escola Nacional de Administração Pública (Enap).

Em 2005, a grande virada em termos de imagem - o Plano Aquarela. A 
promoção do turismo brasileiro no mercado internacional tem, a partir desta data, como conceito estratégico, a diversidade. O trabalho de marketing passa a orientar a construção do Brasil como destino turístico sem dúvida de natureza exuberante, sol e praia, do carnaval e do futebol, mas, sobretudo, passa a comunicar uma nova mensagem: a de país moderno, com indústrias e serviços inseridos globalmente, com credibilidade econômica, alegre, jovem, hospitaleiro, capaz de proporcionar lazer de qualidade, novas experiências aos visitantes, realizar negócios, eventos e incentivos e ser competitivo internacionalmente.

Passa a ser chave no programa de promoção, marketing e apoio à comercialização a essência da cultura brasileira, sua qualidade, diversidade étnica, social e natural. Como exemplo, para adotar esta prática, podemos observar o dinamismo no crescimento turístico de outros países em desenvolvimento (China, África do Sul, Malásia, Indonésia e Turquia).

Estes países cresceram em turismo internacional a taxas médias que variam entre $11 \%$ e $15 \%$ ao ano nos últimos vinte anos. Cabe salientar que Malásia, Turquia e Indonésia não representam, a priori, modelos de interesse para o Brasil. Já China e África do Sul apresentam não apenas produtos semelhantes em segmentos de grande potencial para o Brasil (aventura, ecoturismo, sol e mar etc.), como também desenvolveram planos de marketing extremamente profissionais, competentes e eficazes.

Entre 1980 a 1997, a África do Sul passou da 55ª para 26ª posição no ranking da Organização Mundial do Turismo (OMT), apresentando um crescimento médio de $12,82 \%$ ao ano. Já o Brasil, que se encontrava na 39a posição em 1980, caiu uma posição em 17 anos, descendo para a 40ª com um crescimento médio de $4,85 \%$ ao ano.

Deve-se considerar também que este mercado cresce a taxas excepcionais, envolve cifras bilionárias em dólares e, por conseguinte, é altamente competitivo, disputado e lucrativo. Este é o cenário e o negócio que a Embratur assumiu o compromisso de enfrentar a partir de 2003, por meio da implantação e do desenvolvimento dos programas que vimos citando até aqui.

Para se ter uma idéia do tamanho e da taxa de crescimento do mercado 
internacional do turismo após a Segunda Guerra Mundial, vide a seguinte tabela, elaborada pela OMT, que só considera o turismo fora das fronteiras do país de residência do viajante, ou seja, não é computado aqui o movimento do turismo interno.

\section{Crescimento do Mercado Internacional do Turismo após a Segunda Guerra Mundial}

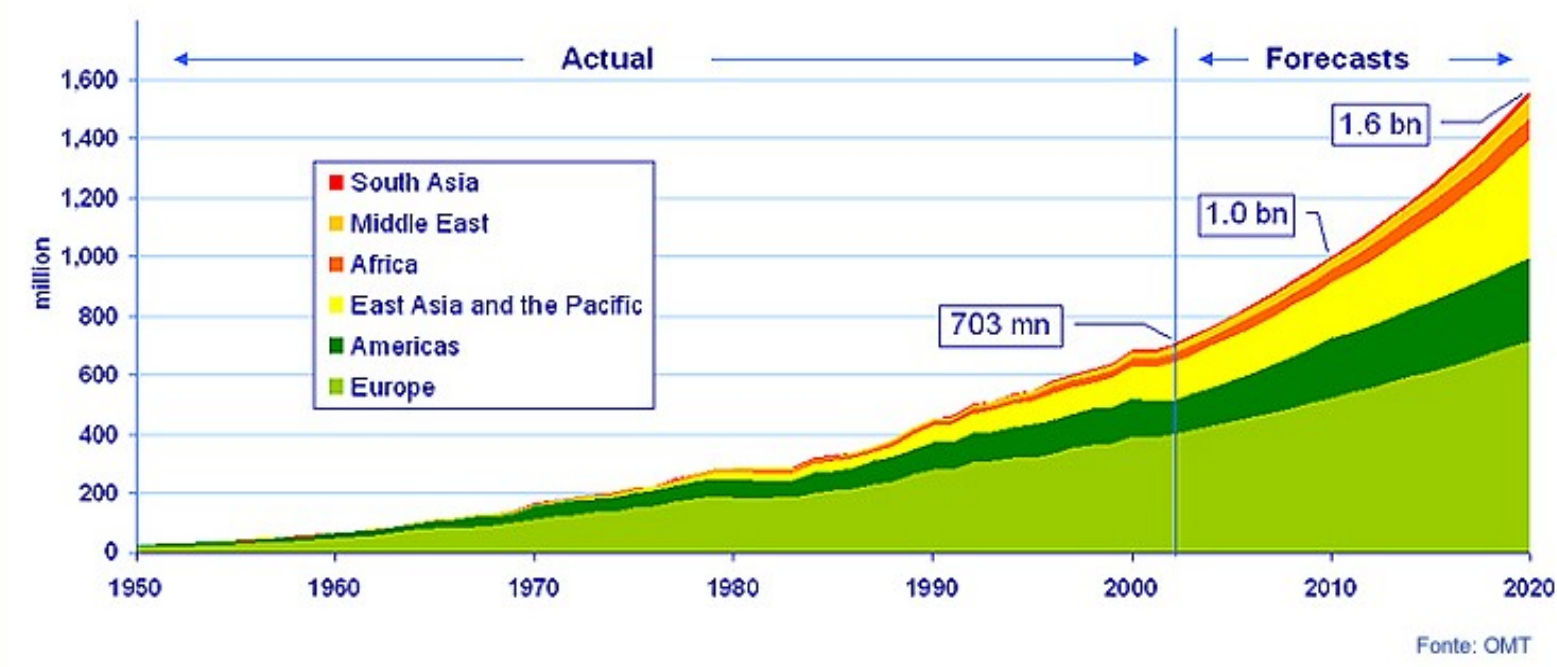

Gráfico 1 - Crescimento do Mercado Internacional do Turismo após a Segunda Guerra Mundial Fonte: OMT

Se não bastasse, aliado a isto deve-se incorporar os desafios lançados pelo PNT, o qual, além de ser o primeiro que define metas claras a serem atingidas pelo setor, quantifica estas metas por meio de verificadores mensuráveis objetivamente e consagrados pelo mercado (estatísticas publicadas pelo Banco Central - Bacen, pela Empresa Brasileira de Infra-estrutura Aeroportuária - Infraero, e pela Polícia Federal DPF), visando: a obtenção do incremento do número de turistas estrangeiros recebidos no Brasil; o aumento das entradas de divisas; suas conseqüências na geração de emprego e renda no país - e tudo isso com taxas de crescimento nunca experimentadas no caso brasileiro.

Elaborado a partir das experiências profissionais de cada um dos executivos da equipe gestora da Embratur, o que lançamos ao ar no primeiro biênio da experiência aqui descrita e analisada foi um conjunto de programas nas três áreas-chave: promoção comercial; apoio à comercialização; e comunicação e marketing. Ora, existem dois enfoques metodológicos de planejamento para obtenção dos objetivos de 
crescimento turístico de um país: o primeiro, a partir da existência de atrativos naturais ou culturais, mas, ainda, sem produto turístico, onde se dá prioridade para a formulação do Plano de Desenvolvimento Turístico, já que, sem produto, não existem turistas; e o segundo é aquele que, como no caso do Brasil, tomando como base os produtos existentes, inicia-se o Plano Estratégico de Marketing Turístico, que busca atrair mais turistas e, concomitantemente, atua-se como acelerador do processo de modernização do próprio mercado turístico.

A contratação desse Plano Estratégico de Marketing Turístico Internacional, intitulado Plano Aquarela, está norteando, de forma científica e planejada, todas as ações da Embratur para os próximos dez anos. Isto é absolutamente inédito não apenas em relação à Embratur, mas de maneira mais ampla, em toda a história econômica do turismo no Brasil.

O Plano Aquarela mapeou os nossos mercados-alvo, indicou os produtos a serem trabalhados em cada mercado, definiu as prioridades na alocação de recursos e o volume desse aporte. Sua implementação está agora na segunda fase, praticamente obtendo a perenidade nos investimentos de curto, médio e longo prazo para consolidar a imagem do país que se quer fixar.

Nosso objetivo com este projeto de doutorado é identificar, a saber:

- Do ponto de vista concreto, se o modelo de gestão e os programas implantados na Embratur a partir da criação do Mtur em 2003 foram eficazes para a economia nacional. Para isso, utilizaremos parâmetros considerados inquestionáveis do ponto de vista técnico-científico;

- Do ponto de vista teórico, identificaremos os pontos de estrangulamento enfrentados ao longo do percurso, problematizando e propondo, quando for o caso, um novo modelo de gestão, apto a superar as dificuldades ora enfrentadas no atual patamar de desenvolvimento das atividades de promoção comercial do turismo brasileiro no exterior.

A título de exemplo, descrevo sucintamente:

Resultados mensurados em 2003:

- a entrada de turistas no país passou de 3.783.400, em 2002, para 4.090.590, em 
2003, com uma variação de $8,12 \%$;

- os desembarques de vôos internacionais regulares passaram de 4.630.062, em 2002, para 5.375.343, em 2003, variação de 16,10\%; enquanto os desembarques internacionais em vôos fretados aumentaram 69,41\%, passando de 101.617 desembarques, em 2002, para 172.150, em 2003;

- o ingresso de dólares mensurado pelo Bacen passou de US\$1,99 bilhões em 2002 a US\$2,48 bilhões em 2003;

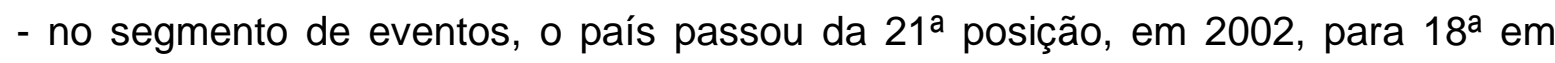
2003, no ranking da International Congress and Conventions Association (ICCA), como realizador de eventos internacionais ${ }^{1 .}$

Resultados mensurados em 2004:

- foram registrados 6.138.217 desembarques contra 5.375.343, em igual período do ano anterior, perfazendo um aumento de 14,2\%. Os desembarques em vôos internacionais, em 2004, no Brasil, foram, também, 11,54\% superior ao do ano de 1998, que havia sido o melhor da história da aviação brasileira, quando foram registrados 5.502 .966 passageiros;

- ademais, o país recebeu 327.273 desembarques internacionais de vôos fretados, em 2004, contra 172.150 desembarques, em 2003, perfazendo um aumento de 90,11\%. Com ocupação, aproximada, de 70\%, cada vôo fretado traz, em média, 210 passageiros, praticamente todos turistas de lazer, em busca de sol e mar, que acabam descobrindo a diversidade cultural e natural do Brasil;

- em termos de entrada de divisas, os dados preliminares advindos do Estudo de Demanda Turística - 2004, que além dos dados do Bacen, incluem outros gastos efetuados pelos turistas, apontam para uma arrecadação de US\$ 3,8 bilhões, contra US\$ 3,4 bilhões do ano anterior. Dessa forma, se o turismo fosse considerado produto, ele estaria na $3^{\underline{a}}$ posição na pauta de exportações brasileiras;

- além dos números serem alvissareiros ainda cabe registro sobre alguns fatos. Desde que o Bacen começou a fazer o registro na conta de viagens - em 1947 para

\footnotetext{
${ }^{1}$ Eventos internacionais, de acordo com a ICCA, são aqueles regulares, que acontecem a cada ano em um país diferente, estão pelo menos na sua $4^{\underline{a}}$ edição e reúnem mais de 50 participantes. Em 2002, o Brasil realizou 56 eventos desse tipo, passando para 62, em 2003. A cidade do Rio de Janeiro foi a maior realizadora, com 30 deles. Os 32 restantes aconteceram em outras cidades como São Paulo, Salvador e Curitiba.
} 
registros anuais e em 1969 para saldos mês a mês - o país bateu, em 2004, três recordes: em janeiro com a entrada de US\$296 milhões; em março com US\$ 308 milhões; e em dezembro com a entrada de US\$ 335 milhões;

- ademais, de 1995 a 2002, o país teve um déficit na conta de viagens da ordem de US\$ 19.949 milhões, situação que se reverteu, em 2003, com um superávit de US\$ 218 milhões e em 2004, de US\$ 351 milhões.

Resultados mensurados em 2005:

- os números finais do Bacen não deixam dúvidas: 2005 foi o melhor ano da história do turismo brasileiro. Com a entrada de US\$360 milhões com turistas estrangeiros no Brasil em dezembro (o número é igual ao de agosto de 2005, que havia sido o melhor mês da série histórica), o ano fechou com o total de US\$3,861 bilhões, um crescimento de $19,83 \%$ com relação a 2004 , que fechou com US $\$ 3,222$ bi;

- já os desembarques em vôos internacionais do ano, de acordo com a Infraero, ratificam estes números e também são recordes. Com o fechamento de dezembro, que apontou um total de 586.138 chegadas em aviões vindos do exterior, o ano somou 6.784.554 desembarques. O crescimento de 2005 em relação ao ano anterior foi de $10,53 \%$;

- os gastos de turistas brasileiros no exterior também cresceram consideravelmente. De acordo com o Bacen, os brasileiros gastaram US\$ 397 milhões em dezembro. A soma do ano ficou em US\$ 4,720 bilhões. Com isso, em 2005 a conta volta a ficar deficitária, em US\$ 859 milhões, depois de dois anos de saldo positivo. Desta vez, não por diminuição do ingresso, mas como conseqüência da baixa do câmbio e da conseqüente ampliação da capacidade de consumo dos brasileiros em moeda estrangeira.

Resultados mensurados em 2006:

- o Brasil fechou o ano com US\$4,316 bilhões recebidos com a atividade, valor que supera em $11,77 \%$ os US $\$ 3,861$ bilhões registrados em 2005. Recorde histórico;

- os desembarques internacionais de passageiros, que incluem estrangeiros e brasileiros em retorno ao Brasil, também tiveram um desempenho expressivo. Chegaram ao Brasil 6.330.144 passageiros em vôos internacionais (vôos regulares acrescidos de fretamentos). Total apenas $6,75 \%$ inferior ao que havia sido registrado 
nos 12 meses de 2005 (6.788.233 passageiros). Esse número foi afetado diretamente pela crise da Varig, que teve vários de seus vôos cancelados ou as linhas subtraídas durante o ano.

\section{Gastos de turistas estrangeiros no Brasil}

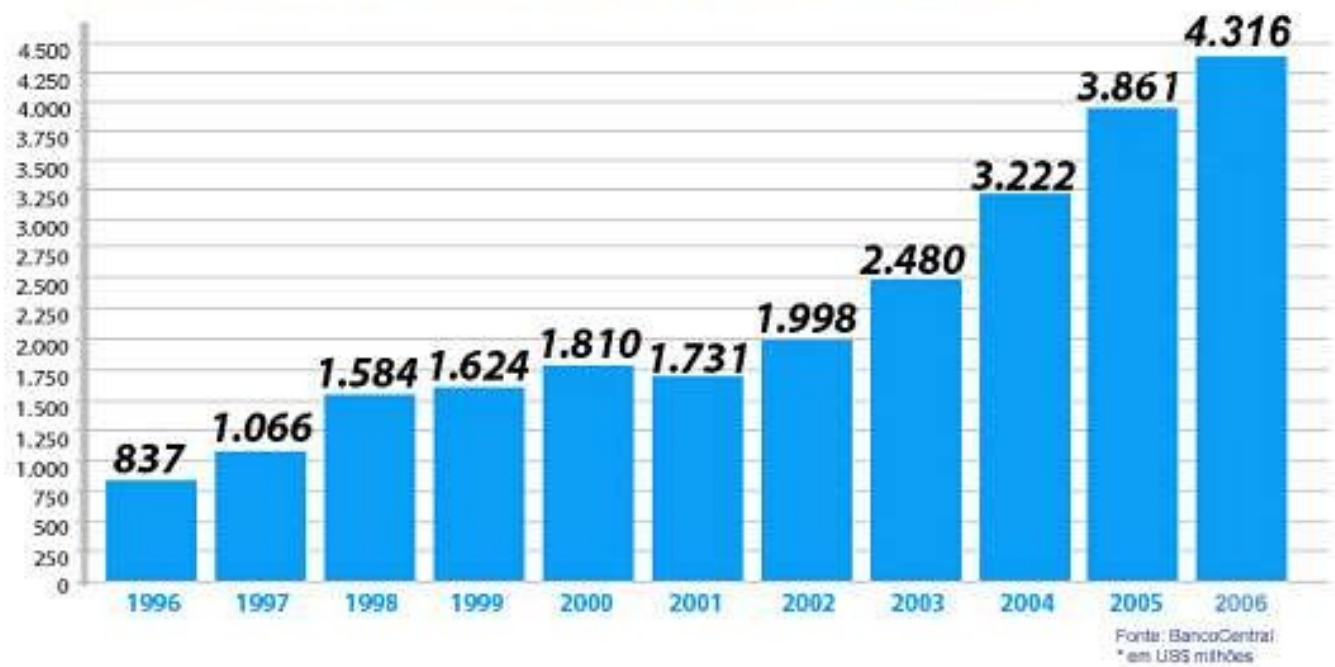

Gráfico 2 - Gastos de Turistas Estrangeiros no Brasil Fonte: Bacen

Este trabalho é uma pesquisa documental exploratória, com pesquisa de campo e estudo de caso, qual seja, aqui não há ruptura com os modelos clássicos de elaboração e construção de uma tese de doutorado. No entanto, pela fragilidade dos dados estatísticos disponíveis, particularmente aqueles produzidos pela própria Embratur ao longo dos anos 1990, as fontes mais ricas deste trabalho são os diversos gestores dos programas analisados, tanto na estrutura pública, como seus parceiros de execução nas entidades e empresas parceiras. Eles tiveram como critério o rigor técnico na elaboração dos programas e a busca por resultados em sua execução. Este trabalho portanto é também um estudo comparativo dos resultados obtidos por um órgão federal a partir da mudança de foco implementada, com conseqüências por todo o país e destacadamente na imagem deste país em relação ao mundo.

Destaque-se que o maior desafio também é a maior contribuição deste doutorado: trata-se da primeira tentativa de sistematizar tecnicamente, sob o rigor 
demandado para um trabalho desta ordem, na Universidade de São Paulo, a transformação de uma velha autarquia em uma unidade de promoção e marketing. Aqui se instala o desafio, por não existir referencial teórico na literatura nacional. A produção teórica do turismo brasileiro, embora crescente, tem se debruçado, por um lado sobre segmentos e temas (meio ambiente, patrimônio histórico) e por outro tem analisado o setor turismo a partir do que o aparelho de Estado produz.

O que nenhum trabalho analisou até aqui foi o próprio aparelho de Estado do ponto de vista de sua eficiência e eficácia em relação ao turismo, assim como sua forma de organização e os conceitos que o levaram a configurar-se tal como estava em janeiro de 2003.

Pois bem, quanto a formas e modelos de gestão e promoção em turismo, temos três modelos disponíveis:

- Públicos tradicionais: Secretarias, Autarquias etc.;

- Privados: tais como os CVBs (no caso brasileiro, pois na Europa são majoritariamente públicos e nos USA recebem taxas coletadas pelo aparelho público);

- Compartilhado: no qual o primeiro caso foi a cidade de Barcelona, cujo modelo de gestão tive oportunidade de detalhar quando da apresentação de minha dissertação de mestrado, seguido atualmente por novas iniciativas, destacadamente na Europa.

Um tema a ter sempre em conta é a fragilidade das instituições e entidades que compõem o que Beni (1998) conceitua como Sistema Nacional de Turismo. O que a experiência em Brasília ensina é que tanto estados e municípios, assim como a grande maioria das entidades representativas e dos meios de informação especializados ligados ao setor, são dependentes de recursos federais. Portanto, a criação e a determinação de qual é a agenda a ser implementada no processo de desenvolvimento do turismo nacional, assim como as relações entre entidades, veículos e agentes institucionais, está matizada por este desequilíbrio econômico. A necessidade de um novo desenho institucional, portanto, é mister, inclusive, para inserirmos outros agentes no processo, com capacidade de ação econômica, pois serão também capazes de formular novas agendas e mais, ainda, fazer pautar novas demandas.

Ainda no campo de demarcação teórica do que procuramos demonstrar neste 
texto, permito-me avançar em outra questão: apesar da pouca literatura disponível sobre as relações entre organizações públicas, privadas e a gestão do turismo, colegas da melhor qualidade vêm procurando contribuir para com a reflexão sobre este relacionamento. No entanto, por melhor que sejam essas contribuições, são, quase sem exceção, reflexões sem o crivo da práxis. Ou seja, a produção teórica fica nos marcos determinados pelo excelente exercício da reflexão, análise e revisão de conceitos clássicos, que vão sendo superados a cada passo do desenvolvimento das atividades econômicas relacionadas a turismo, sem, no entanto, confrontar-se com o exercício cotidiano de tomar decisões, eleger prioridades, checar resultados e buscar superá-los. Mais ainda, sem submeterem-se ao crivo do exercício de comunicar e debater em diferentes níveis, quer sejam públicos, quer sejam institucionais ou privados, os resultados obtidos.

Não é novidade, há dezenas de textos indicando isso, que há um volume de conflitos interorganizacionais, internos ao aparelho de Estado, tanto horizontal como verticalmente, assim como há conflitos de interesse vigentes nas disputas explícitas nas relações econômicas, atuando sobre uma atividade na qual a gestão de recursos naturais e culturais freqüentemente se choca com programas de desenvolvimento e a necessária implantação de equipamentos e programas de infra-estrutura. Também não é novidade, e novamente os textos são abundantes, que estes conflitos acabam por dificultar a elaboração e a implantação de estratégias amplas e consistentes de desenvolvimento da atividade turística em nosso país.

Onde a literatura é frágil é no campo das proposições e da verificação sistematizada sobre casos concretos. E, aí, insere-se a importância e o ineditismo deste trabalho: o período compreendido entre a criação do Mtur no Brasil e a redefinição do papel da Embratur, em 2003 e os dias que correm, já em 2007, é o primeiro em toda a história da promoção comercial do turismo brasileiro no exterior em que o País vive um processo contínuo e mensurável de crescimento, no qual os gargalos históricos imagem, orçamento, acesso aéreo internacional fora do eixo SP/RJ, inserção no segmento corporativo, ação permanente no exterior, e outros - são enfrentados e tornam-se alvos de programas de trabalho sustentados pela Embratur e apoiados pelos agentes econômicos privados e institucionais. 
É a constatação de que há um novo "teto" avizinhando-se, impondo a superação agora de outro limitador - a quase inexistente participação privada no esforço de promoção do Brasil, que nos leva à opção pelo que apresentamos na conclusão do trabalho: o programa de um novo modelo de gestão para a promoção do Brasil, superando esta dicotomia nas relações supramencionadas e apontando um instrumento capaz de inserir de forma organizada outros setores, que não apenas a união, como protagonista desse processo.

O Governo Federal, ao criar o Mtur e, por conseqüência, trazer o setor turístico ao patamar de âncora de um novo programa de desenvolvimento econômico mensurando ainda os resultados que foram se apresentando - criou um desafio ao desenvolvimento do setor - formular um conjunto de programas que apontem para a solução de problemas históricos do turismo brasileiro:

- A fragilidade técnica e econômica das estruturas de representação institucional do setor;

- O esgotamento do modelo fomentado exclusivamente pelo orçamento da união, no que diz respeito à promoção internacional.

Os objetivos deste novo modelo, tendo o Ministério como responsável por três unidades - duas secretarias nacionais e uma autarquia - definem para a Embratur as seguintes missões:

- Estratégicas:

Formular, implementar e executar as ações de promoção e marketing dos produtos, serviços e destinos turísticos brasileiros no exterior, visando o aumento da chegada de turistas estrangeiros, assim como, o tempo de permanência e o ingresso de divisas no território nacional, com a finalidade de ampliar o mercado de consumo e, conseqüentemente, a produção e a aquisição de bens e serviços gerados no país, impactando positivamente o volume de emprego e renda no Brasil.

- Específicas:

. Diversificar a oferta turística brasileira;

. Ampliar o mercado de trabalho;

. Aumentar a inserção competitiva do produto turístico no mercado internacional; e 
. Aumentar a taxa de permanência e o gasto médio do turista.

- E os beneficiários são:

. A Cadeia Produtiva do Turismo;

. O mercado formal e informal de emprego;

- A economia nacional, particularmente em regiões não beneficiadas pelos processos de desenvolvimento agrícola ou industrial.

Esta Embratur que surge em 2003, e que tem, como atribuição exclusiva, as ações de promoção junto ao mercado internacional, fará parte de um sistema no qual as atividades voltadas ao mercado interno (portanto, todas as atribuições antigas da autarquia relativas a políticas públicas, normatização, regulamentação, fomento, subsídio a obras e sustentação a inúmeras atividades desenvolvidas em território nacional), passam a ser de atribuição da administração direta, qual seja, das duas Secretarias Nacionais do Mtur.

Os primeiros passos da equipe que assume a direção da nova estrutura são baseados fundamentalmente na experiência pregressa desta mesma equipe. E este é o primeiro item que a diferencia (e os resultados posteriores deixaram isso claro) na história da autarquia: na medida em que toda a equipe é formada por profissionais do setor, com origens diversas quanto a região, formação, experiência profissional e geração, mas tendo seus membros experiência de atuação em nossa área, as medidas a serem implantadas, e as tarefas decorrentes, entre elas o necessário debate aberto com o setor, foram enfrentados logo de saída com muita tranqüilidade. Isto deu ganho de tempo e escala ampliada de trabalho à nova feição da Embratur.

Em nosso primeiro seminário de planejamento (prática que repetiríamos semestralmente durante os quatro anos seguintes, reunindo todos os diretores, gerentes, coordenadores, técnicos-chave e assistentes de cada unidade), definimos que cada ano de nossa primeira gestão enquanto equipe teria um eixo:

2003 - Seria o ano do Turismo de Negócios e Eventos;

2004 - Seria o ano do Turismo de Lazer e Incentivo;

2005 - Seria o ano do Programa de Marketing e Relações Públicas;

2006 - Seria o ano de consolidar junto ao governo, ao mercado e à sociedade, por meio de Dados, Fatos, Estudos e Pesquisas, todas as inovações que 
implantássemos nos anos anteriores.

Ainda em 2003, a partir das definições estratégicas, fizemos a reorganização administrativa da autarquia. As antigas diretorias, divisões e seções, foram substituídas por uma estrutura condizente com as práticas de gestão correntes no mercado. Surgem as cinco diretorias - com destaque para as três novidades: Negócios e Eventos, Lazer e Incentivo, e Estudos e Pesquisas -, as chamadas diretorias de combate que se somam a duas unidades já tradicionais - Marketing e Administração e Finanças -, e surgem também as gerências e as coordenações. Como decorrência, não da reorganização, mas antes de tudo, da reorientação de foco e de área de atuação, poucos profissionais que vinham de experiências anteriores permaneceram na equipe muitos por não terem experiência no mercado internacional, outros por não terem experiência específica em turismo, outros por simplesmente não dominarem outro idioma.

A marca do ano de 2003 é a revisão completa e a triplicação de nossa presença em feiras internacionais, a criação dos programas de captação de eventos internacionais e a articulação com a Agência de Promoção de Exportações do Brasil (Apex) para o programa de promoção internacional das feiras comerciais realizadas no Brasil.

Quanto ao ano de 2004, seus destaques são a criação dos EBTs, a criação dos Bureaux de Promoção Comercial e a criação da Caravana Brasil.

$E$ foi aí que enfrentamos nosso primeiro gargalo, nos convencendo de que a atual estrutura de gestão, autárquica, tem limites que não consegue superar: com dois anos de trabalho, a estrutura apresentava um volume de resultados inédito para o país, como veremos mais adiante, e girava com um ritmo de trabalho que não conseguiria manter em crescimento estes mesmo resultados pelo período necessário à mudança de patamar que desejávamos para o turismo brasileiro.

Dessa certeza surge a contratação, já no ano de 2005, do Plano Estratégico de Marketing do Turismo Brasileiro, o primeiro na história do país, intitulado Plano Aquarela, que:

a) criou uma marca para o país;

b) ouviu todos os segmentos relevantes da cadeia produtiva do turismo, sendo, 
portanto, plural na sua essência; e

c) pesquisou mercados-alvo e consumidores atuais e potenciais, dando à Embratur uma gama de informações e de instrumentos que se tornaram a linha mestra e o propulsor das ações da organização.

Este Plano deu nova feição à Embratur, norteou as suas ações para o público externo e fundamentou a repactuação da parceria governo $x$ sociedade no setor turístico brasileiro. Registre-se ainda que, na medida em que o Plano vem sendo assumido pela sociedade, sua temporalidade passa a descolar do período de Governo para que as ações em curso no exterior não sofram solução de continuidade com eventuais mudanças de gestão.

A história mostra que os países que obtiveram sucesso mundial no setor turístico têm em comum um planejamento bem fundamentado tecnicamente, que viabilizaram e sustentaram um investimento perene do país independente do titular do governo. Esse é um dos principais paradigmas da administração pública que a proposta de reorganização da Embratur pretendia suplantar. É de se convir que se fosse a única já não seria uma tarefa fácil.

Isso porque, entende-se na Embratur que o planejamento estratégico é um processo contínuo de pensamento sobre o futuro, acionado num contexto de interdependência e mudança. Ele pressupõe um ciclo decisório que ocorrerá antes, durante e depois de sua implementação; que deve ser considerado, antes de tudo, como um modo de pensar; e que tem uma dimensão para cada nível de decisão. Dessa crença derivam os diversos fóruns internos e externos de discussão e decisão. Ademais, ele necessita de uma sistematização para sua implementação. O diagrama, abaixo, demonstra isso: 


\section{Alinhamento estratégico}

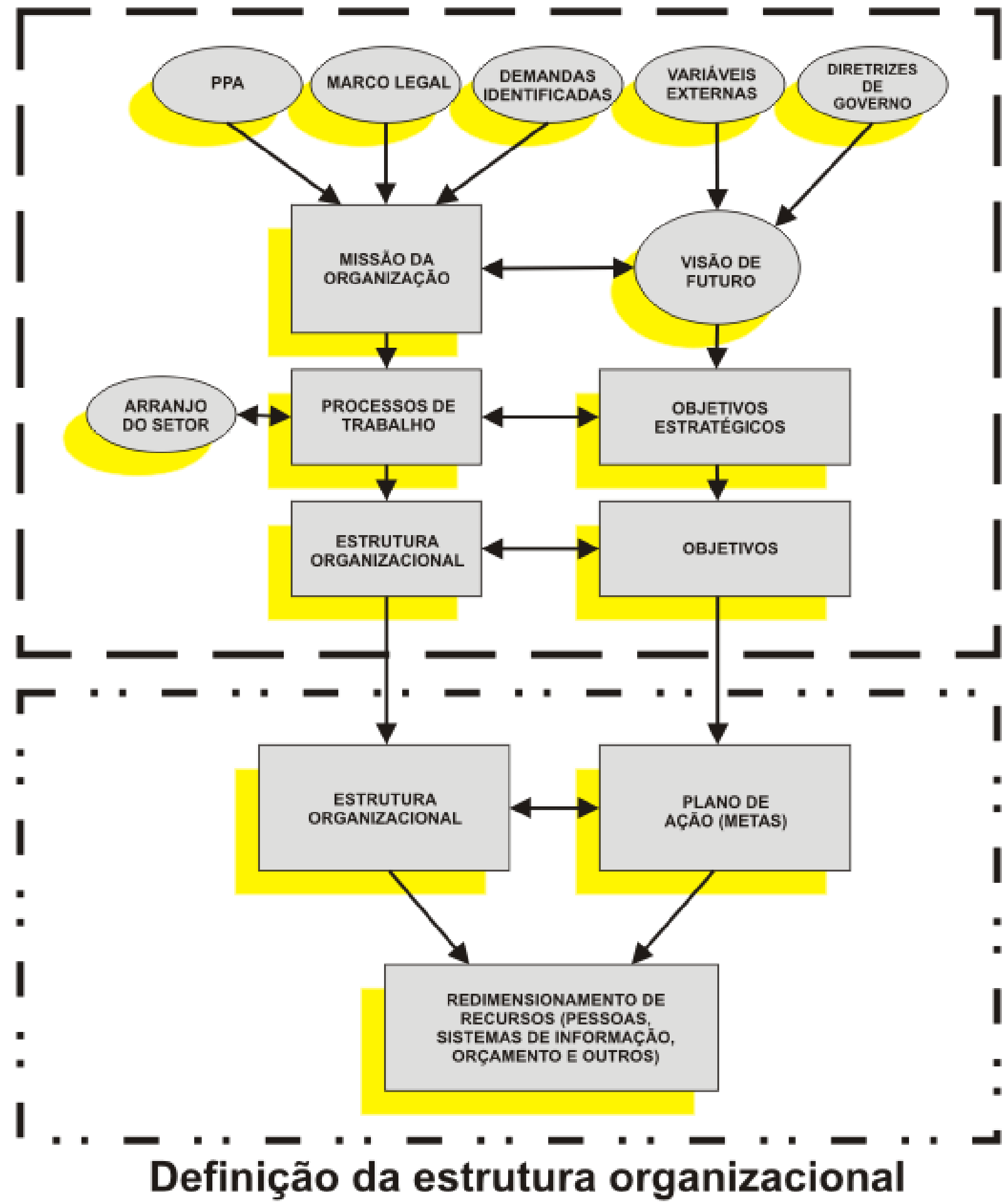

Diagrama 1 - Alinhamento Estratégico e Definição da Estrutura Organizacional Fonte: Secretaria de Gestão e Orçamento do Ministério da Fazenda 
Conforme o diagrama, já foram ultrapassados os estágios do Plano Plurianual (PPA); Marco Legal; Demandas Identificadas; Variáveis Externas e Diretrizes de Governo. Além disso, já se definiu a Missão; Visão de Futuro e os Objetivos.

Os processos de trabalho estão desenhados, implantados e já passam por programas de revisão e reordenamento; o arranjo do setor depende, em parte, da seqüência de implantação do Plano Aquarela.

A Embratur continua a se propor a intensificar o processo de modernização da sua gestão. Sendo que, vale mencionar, algumas das ações que estão sendo adotadas já vêm sendo há décadas praticadas nos países de ponta no setor turístico, caso dos EBTs, cuja primeira experiência ocorre na década de 1920 com a criação dos escritórios espanhóis em Londres e Paris, com programas de trabalho que rapidamente se desenvolveram, após a percepção do equívoco inicial, de maneira independente da estrutura diplomática. Aonde inovamos, ao adotar práticas de sucesso e de reconhecimento internacional, foi em atração de apoio técnico e reconhecimento público nas estratégias implementadas. É inequívoco que existia, também, um vácuo deixado pela história de atuação da autarquia, que não tinha, como dissemos, registros de grande repercussão, nas ações que havia desenvolvido no mercado externo.

Desde 2003, com a nova estrutura, sinteticamente descrita abaixo, os resultados dos programas da Embratur passaram a ser medidos a partir de critérios estritamente técnicos, definidos por instituições externas à autarquia, reconhecidas por sua tradição e credibilidade. Cada um dos programas, descritos no próximo capítulo, só tiveram prosseguimento depois de comprovadamente verificarmos que seria possível apresentarmos resultados mensuráveis ao governo, ao mercado e à sociedade, em cada um deles.

Aqui romperíamos com mais um paradigma: o turismo brasileiro passava a ter dados para avaliar, criticar e ajustar as ações de seu principal protagonista em promoção e marketing. A Embratur nunca havia gerado estas informações, muito menos disponibilizado estes dados ao mercado com chancela de organismos de indiscutível credibilidade. O primeiro exemplo foi o agora já habitual informe de divulgação mensal do volume de gastos deixados pelos turistas estrangeiros no Brasil dado pelo Bacen. Esta informação passou a ser um termômetro importante para medir 
resultados das ações da Embratur assim como para balizar novos programas. Outros três dados também passaram a ser parâmetros para medição:

1. o desembarque de passageiros em vôos internacionais regulares, mensurados pela Infraero; e, a partir desse,

2. também o volume de desembarques somente em vôos charters. Isso porque nos vôos internacionais regulares estão também contabilizados viajantes brasileiros que regressam ao país, enquanto nos charters, os passageiros são todos turistas;

3. o último dado geral de verificação, este do DPF, contabiliza o número de estrangeiros que visita o país anualmente.

Os números publicados pela OMT comprovam que o turismo internacional, no Brasil, a partir de 2004, vem crescendo acima da média mundial. Isto indica que o país vem tirando mercado de alguns concorrentes. A reação desses e de outros concorrentes que se sintam ameaçados já se faz sentir, e temos exemplos no México e na Argentina, na medida em que ambos refizeram suas marcas e realinharam suas estratégias promocionais.

O ano de 2006 foi especial para toda a nossa equipe: foi o ano da consolidação dos dados e dos fatos pelos quais pautamos todo o programa. Vale relembrar aqui o pronunciamento que fiz quando nossa equipe assumiu a Embratur, no Auditório do Ministério dos Esportes, em 26 de janeiro de 2003:

\footnotetext{
Esta não será mais uma Embratur de discursos. Iremos disputar cada passageiro, iremos procurar ocupar cada assento de avião, cada quarto de hotel, e cada serviço prestado por agentes brasileiros, e mais, iremos submeter todas nossas ações ao julgamento da sociedade e do mercado, por meio da criação e disponibilização de um conjunto de informações de absoluta transparência e credibilidade...
}

Portanto, não por acaso 2006 foi o ano em que os Boletins de Desempenho Econômico do setor passaram a ser divulgados com relevância cada vez maior. Assim como, foi com prazer que assistimos aos veículos de comunicação - TV, jornal, rádios e internet - por meio de seus programas mais expressivos, habituarem-se a contatar a Embratur para obter o volume de entrada e saída de dólares ocorrido no mês anterior no país, segundo o Bacen, já analisados e comentados por nossa equipe técnica. Foi, e isso se pode afirmar não sem uma ponta de orgulho, o ano em que todos os recordes 
do turismo brasileiro foram superados.

O desafio agora é superar as limitações históricas da velha autarquia, substituindo-a por um outro modelo de gestão, que dote o turismo brasileiro de instrumentos capazes de manter-nos com o mesmo ritmo de crescimento e desenvolvimento verificado nesses últimos três anos. Já abordei este tema, de uma forma inicial, quando da apresentação de minha tese de mestrado junto ao Departamento de Publicidade, Relações Públicas e Turismo da Escola de Comunicações e Artes da Universidade de São Paulo, em 2001 (SANOVICZ, 2001). Tratava, naquele momento, do modelo de gestão de turismo da cidade de Barcelona, Espanha, fazendo um estudo comparativo com a prática adotada em Santos, São Paulo, ao início da década de 1990. Agora, neste trabalho, abordo, e aqui com uma possibilidade concreta de implantação prática do estudo teórico, a possibilidade de virmos a dispor no Brasil, de um formato de gestão ágil e moderna, que precisará estar disponível para que o País se torne um "jogador" importante no cenário turístico mundial.

Para dirimir essas questões tem-se, atualmente, que os desafios administrativos são:

1. auferir uma receita perene;

2. obter agilidade gerencial e administrativa;

3. aprofundar o processo de planejamento e compromisso.

Para tanto, uma das fórmulas estudadas é a proposição de uma nova personalidade jurídica para a Embratur, que realize de forma orgânica a inserção do setor privado na gestão e no custeio das atividades de promoção marketing, por meio da formalização de um contrato de gestão com o governo federal, representado por um processo de pactuação de metas e resultados. Desta forma o Brasil passa a um novo patamar neste cenário, partindo de um modelo estatal para um modelo público de gestão em promoção turística.

Outras duas considerações relevantes no atual programa de gestão, que deve ser referência para o próximo estágio: até 2003, não havia um critério claro e acordado entre todos os estados brasileiros para a distribuição das verbas de promoção federal. Este montante, usado livremente pelas secretarias de turismo dos estados para 
promoção de seus destinos, não costumava ser definido previamente em qualquer orçamento federal nem seus critérios definidos de antemão. Em 2003, o Mtur e a Embratur criaram, em cada um dos 27 estados, um fórum estadual de turismo, representado pelos poderes público e privado, composto por agentes econômicos ligados ao turismo. Junto com eles, o Mtur e a Embratur propuseram uma regra de distribuição das verbas federais, a partir de critérios como estrutura de turismo que cada estado possuía e número de feiras e outros eventos que, no caso, a Embratur era promotora, em que o estado participava. Isso gerou uma mudança de postura dos estados, que passaram a discutir entre eles quais eram as maneiras de distribuir e utilizar esse dinheiro, de forma absolutamente transparente. Tal mudança ocasionou, por conseqüência, processos semelhantes nos próprios estados, fossem entre as cidades, fossem entre os diferentes segmentos de turismo.

Nessa mesma linha, agora falando de parcerias, só foi possível implementar os diversos programas na Embratur ao longo destes anos com a participação e, principalmente, comprometimento, do mercado e das entidades do turismo brasileiro. Eles se tornaram protagonistas de vários projetos, pela compreensão de que qualquer programa tem que ser adotado pelo mercado para poder dar resultados e, mais que isso, garantir a sua continuidade. Há exemplos diversos, como a Caravana Brasil, projeto que traz operadores estrangeiros para conhecer destinos brasileiros e que é operacionalizado pelas duas principais entidades desse setor: Brazilian Incoming Travel Organization (Bito) e a Associação Brasileira das Operadoras de Turismo (Braztoa). Outros exemplos estão descritos no próximo capítulo.

\section{Cronologia}

18 nov./1966 - É criada a Embratur pelo decreto lei 55, definindo uma política nacional para o setor.

28 mar./1991 - A Embratur é transformada em Autarquia Especial, vinculada à Secretaria de Desenvolvimento Regional da Presidência da República. Passa a se chamar Instituto Brasileiro de Turismo.

Final de 1990 - A sede da Embratur sai do Rio de Janeiro, sendo transferida para Brasília. 
1999 - A Embratur é subordinada ao Ministério do Esporte e Turismo Jan./2003 - É criado o Mtur. A Embratur passa a ser o órgão exclusivo de promoção, marketing e apoio à comercialização dos produtos, serviços e destinos brasileiros no exterior.

Abr./2003 - É lançado o Plano Nacional de Turismo, pelo Mtur, com metas até 2007. 11 de set./2003 - Criado o primeiro EBT, para a América do Sul (sede em Brasília). Out./2003 - É realizada a primeira Caravana Brasil. Jan./2004 - É inaugurado o primeiro EBT, em Lisboa (Portugal).

O DPF divulga que, pela primeira vez na história, os turistas europeus superam os latino-americanos em chegadas ao Brasil.

Embratur passa a divulgar, mensalmente, 0 volume de gastos dos estrangeiros no Brasil.

É divulgado o Plano Aquarela - Plano de Marketing Internacional. Abr./2005 - Durante a International Tourism Exchange (ITB), em Berlim, é apresentado o novo layout do estande brasileiro.

21 de mai./2005 - Primeira viagem de benchmarking (Costa Rica).

23 de set./2004 - Primeiro seminário Descubra o Brasil (Inglaterra).

19 de set./2006 - Primeiro treinamento on line do Programa Agente de Viagens Especialista em Brasil (Lisboa).

Esta pesquisa é o resultado da reflexão teórica efetuada a partir de quatro diferentes passagens que tive, sempre em posições de comando, em estruturas de gestão de turismo (ou eventos, no caso do Anhembi):

- a primeira, uma unidade pública de administração direta - o Departamento de Turismo de Santos;

- a segunda, uma organização privada, o São Paulo CVB;

- a terceira, uma empresa de economia mista - o Anhembi Turismo e Eventos da Cidade de São Paulo;

- e, por fim, uma autarquia federal, a Embratur.

Para completar meu quadro de referências, tenho que mencionar minha passagem, neste caso em uma posição técnica, pela Turisme de Barcelona, 
organização de promoção da capital catalã, à qual se vincula o Barcelona Convention Bureau.

Como se pode depreender facilmente, a partir de 1993, passo a conduzir ações de promoção e marketing, ora institucional, ora comercialmente dirigidas. Nesta caminhada, na medida em que enfrentei, conjuntamente com brilhantes equipes, dificuldades muito interessantes, tanto do ponto de vista operacional, como do ponto de vista gerencial (e isto vale para tanto para o setor público como para o setor privado), passei a ter como foco de minhas preocupações o modelo gerencial e os marcos legais de gestão, nos quais se definem as ações de promoção e marketing turístico no Brasil até nossos dias.

A primeira oportunidade que tive para expressar com rigor científico estas preocupações foi em 2001, quando da apresentação de minha tese de mestrado (SANOVICZ, 2001), ao descrever a experiência da Turisme de Barcelona, e os primeiros passos, em meados da década passada, de um modelo compartilhado, público-privado, de planejamento, financiamento e execução de ações promocionais. Discorria, e estabelecia comparações entre os programas desenvolvidos em Santos/SP, na primeira metade da década de 1990, com protagonismo público municipal, e aqueles praticados em Barcelona, sob a primeira organização público-privada criada na Europa, com protagonismo compartilhado portanto entre o setor publico e os agentes econômicos privados.

Vem portanto de uma década, desde o ano de 1996, meu interesse e inquietação com este tema. Passei pelo São Paulo CVB e pelo Anhembi, e no segundo pude esboçar alguns passos no sentido de trabalhar o tema: é deste período a cooperação entre o São Paulo CVB e o Anhembi em ações de promoção no Brasil e no exterior, tais como campanhas de mídia e participação em feiras.

Infelizmente, a agenda de prioridades do Anhembi era tão grande, com destaque para:

1. a completa reorganização administrativa e gerencial da empresa;

2. a retomada das obras do hotel, paralisadas desde a década de 1970;

3. a ampliação e renovação da área física para eventos, tanto no Pavilhão de Exposições como no Centro de Convenções, 
que, ao encerrar minha curta passagem de dois anos pela empresa, embora tenha apresentado a primeira gestão com balanço lucrativo do Anhembi desde o final da década de 1980, este assunto - o modelo de gestão - ficou apenas em um estudo que previa, entre outras coisas, a divisão da empresa em duas unidades - uma voltada para a sua função comercial de espaço para realização de férias e eventos e outra voltada para seu papel institucional de promoção e marketing turístico da cidade de São Paulo, assim como uma outra forma de administração, compartilhada com o setor privado. Com certeza estes documentos ainda estão nos arquivos da Anhembi Turismo e Eventos da Cidade de São Paulo.

Ao chegar a Brasília, em janeiro de 2003, trazia comigo além da emoção e da ansiedade, um conjunto de propostas para a estrutura federal de turismo que haviam sido debatidas por um grupo amplo e interessante de profissionais ligados aos diversos segmentos da atividade turística, espalhados por todo o país.

Basicamente, o que tencionávamos era, cientes da fragilidade e da inconsistência das ações de promoção e marketing internacional do turismo brasileiro, criar um conjunto de programas que gerasse resultados diferentes daqueles que 0 Brasil conhecia, até então muito fracos. O roteiro era:

1. Compor uma equipe capaz de enfrentar o desafio (e aí foi preciso renovar praticamente todo o quadro gerencial da Embratur);

2. Ampliar o foco das ações promocionais, saindo da posição tradicional de trabalhar exclusivamente lazer, para a incorporação do tema negócios e eventos a agenda brasileira;

3. No segmento lazer, ampliar os canais de distribuição e mudar por completo os instrumentos e os focos da promoção, ampliando os destinos receptivos inseridos no mercado internacional;

4. Radicalizar em novas práticas de promoção e marketing; e, finalmente,

5. Criar um novo modelo de gestão, que substituísse o isolado protagonismo público, tanto financeiro como organizacional, por uma gestão compartilhada.

Foi possível cumprir plenamente com os quatro primeiros itens, e isto é um dado público e sabido em todo o país, e para nossa alegria, em algumas partes do planeta. Mas não foi possível, e esta tarefa fica para o período que ora se inicia em Brasília, 
implantar o quinto ponto de nosso plano inicial. No entanto, avançamos até a etapa de elaborar um anteprojeto para uma nova entidade de promoção e marketing para o turismo brasileiro; projeto este que deve agora ser implementado pela equipe que segue à frente da Embratur.

Este trabalho que ora apresentamos, descreve, etapa por etapa, cada passo desta trajetória: de como a velha autarquia veio se transformando numa unidade de promoção internacional, e de como é possível agora consolidar estes programas com um modelo equiparado em eficácia e eficiência, a seus agora já existentes, congêneres estrangeiros. 


\section{PROMOÇÃO COMERCIAL}

\subsection{Programa de Feiras Internacionais de Turismo}

Como o fazem todos os países do mundo que possuem estratégias de promoção de seus produtos turísticos no exterior, tradicionalmente o Brasil participa de feiras internacionais de turismo voltadas para agentes de mercado (operadores de turismo e agentes de viagens) e/ou para o público consumidor final (o turista que busca um destino para sua próxima viagem).

Principal programa de promoção internacional da Embratur, desde a década de 1980, o calendário de feiras foi a única atividade que, apesar de completamente reformulada e adaptada às novas estratégias, mantivemos funcionando. As principais reformulações, implementadas com o objetivo inicial de minimamente inserir o Brasil no século XXI, foram:

1. O estudo do calendário em vigor e levantamento de outros eventos que tornassem

o programa mais abrangente em termos de mercados, produtos e segmentos adotados pelos programas da Embratur;

2. A ampliação da participação, o que levou à adoção de uma agenda, em 2003, com 30 feiras, e, em 2004 e 2005, com 40 feiras cada ano;

3. A organização de um "mix" de feiras que fosse mais abrangente em segmentos turísticos - ecoturismo, golfe, eventos, negócios e incentivos -, assim como em termos de mercados, sobretudo na América Latina, onde somente a Argentina estava contemplada com uma feira;

4. A reestruturação da forma de gestão das feiras por meio de assinatura de convênio com a Federação Brasileira de Convention \& Visitors Bureaux (FBC\&VB), opção adotada por tratar-se da mais abrangente e representativa entidade do setor 
privado, com alcance nacional e multisetorial. Esta opção, objeto de polêmica inicial, assim como de resto boa parte dos programas que pusemos no ar, antes que obtivessem apoio e por fim quase consenso em todo o setor, foi uma das primeiras atitudes de revisão conceitual de fundo, na história de promoção do turismo brasileiro.

Isto porque, por mais de uma década, as agências de viagem, por meio de suas entidades, foram as únicas protagonistas dos programas desenvolvidos (ainda que timidamente) pelo governo federal na promoção do turismo. Ora, ao início do século XXI, um movimento iniciado em meados da década de 1980, introduzindo no país os CVB - primeiramente em São Paulo e depois no Rio de Janeiro - por ação protagonizada fortemente pela Varig, começa a gerar reproduções em todo o Brasil. Os CVBs, organizados no Brasil de maneira distinta em relação à Europa (onde surgem) e aos Estados Unidos (onde se instalam quase que imediatamente após), são, em minha opinião, a grande novidade em um modelo organizacional do turismo brasileiro. Suas diferenças fundamentais no Brasil são o fato de que se compõem como organizações privadas sem fins lucrativos. Na Europa são majoritariamente exceção feita a Barcelona a partir de 1993 e atualmente a algumas outras cidades organizações públicas, vinculadas às secretarias de turismo, conforme expliquei em minha dissertação de mestrado (SANOVICZ, 2001), e nos Estados Unidos, embora sob gestão teoricamente privada, sustentam-se com recursos públicos obtidos por meio de impostos. No Brasil, ao contrário, os CVBs são mantidos primeiramente pelo room tax, obtido junto aos clientes pelos hotéis associados a cada unidade local. Secundariamente, estabelecem convênios e acordos com entidades privadas (Associações Comerciais e outras) e com o setor público (em seus três níveis), para o desenvolvimento de suas atividades de promoção de destino e captação de eventos.

Somando-se a isso o fato de gerarem organicidade ao setor receptivo em cada destino, por reunirem sob uma mesma estrutura diferentes segmentos, tais como hotéis, companhias aéreas, centros de convenções, agências de viagem, organizadores de congressos, transportadores e diversos prestadores de serviços, transforma-os em centro catalisador de programas de promoção. 
Foi esta constatação que nos levou a romper um paradigma tradicional do turismo brasileiro: deixar de ter como principal parceiro da Embratur uma entidade que representava exclusivamente agentes de viagem, majoritariamente emissivos, substituindo-a por uma entidade que ao invés de atuar de maneira corporativa, representa um tema - a captação de passageiros e agregava um novo segmento a agenda de promoção do país, até então ignorado - negócios e eventos.

O que parecia inicialmente apenas uma mudança de entidade conveniada, e foi lido de maneira quase simplória por parte do setor, inclusive da mídia especializada, mostrou-se, como queríamos, uma profunda mudança conceitual nas relações institucionais do turismo brasileiro. Trazer os CVBs ao papel protagonista, na medida em que a Embratur e seu orçamento seguem sendo vitais para todo sistema, pela ausência de outros agentes econômicos no processo, quer sejam públicos, quer sejam privados, implicaria - e esta era a estratégia - em elevar cada CVB, em cada cidade, à condição de interlocutor econômico. E foi que se viu nestes últimos anos.

Como conseqüência, observamos:

- o surgimento de novos segmentos e lideranças do setor;

- o despontar de novos destinos brasileiros no mercado internacional;

- o crescimento dos níveis de profissionalização e competitividade nestes destinos; e

- uma saudável redistribuição ao redor do país, de investimentos estrangeiros em promoção e, em seguida, em equipamentos tanto para o segmento lazer, como para o segmento corporativo.

Particularmente, como protagonista do desenvolvimento da rede brasileira de CVBs desde a metade dos anos 1990, senti grande satisfação em poder ser agente deste processo de transformação. Éramos poucos nas primeiras articulações que iniciaram esta caminhada - Aristides Cury e eu, de São Paulo; Moacir, de Porto Alegre; Raimundo Peres, da Bahia; Cabral, de Fortaleza; Sales, de Vitória; Vera Sanches, de Brasília; Jeanine Pires, de Maceió; e Alexandre Raulino, do Rio de Janeiro. Quase uma década depois, ao cumprir-se o compromisso do presidente Lula de profissionalizar a Embratur, não foi por acaso que três de nós tornamo-nos seus diretores, e um quarto foi indicado como primeiro executivo do EBT de Nova 
York.

Hoje, passada uma década daqueles movimentos iniciais, o Brasil conta com 72 CVBs, oito federações estaduais e uma confederação nacional. Estes dados assumem importância ainda maior, se considerarmos que é uma estrutura construída por fora da legislação sindical, sem impostos ou obrigações legais, por meio da obtenção de consensos sucessivos entre agentes econômicos que competem no mercado, mas têm no CVB um espaço comum de atuação e retorno efetivo de seus investimentos.

A nota dissonante neste processo, é importante registrar também, é o surgimento de um número ainda minoritário, mas que de nenhum modo pode ser ignorado, de CVBs e, ainda mais grave, de dirigentes de CVBs, em diversos níveis, que começam a substituir sua inserção no mercado como razão da existência das organizações, pelos subsídios públicos como forma de manutenção e ampliação de suas atividades. Este desvio de esforço, conceito e prática, ainda não se tornou prática ampla junto a estas entidades, mas deve ser revisto antes que venha a inviabilizar um esforço de mais de uma década;

5. A adoção de critérios e tratamento igual a todos os órgãos oficiais de turismo de estados e municípios com formas de participação e oportunidades equivalentes;

6. A redução da contrapartida do conveniado, a fim de possibilitar a ampliação da participação em um maior número de feiras e, sobretudo, de ampliar a atuação dos cooperados que não participavam do programa;

7. A reorganização do estande de forma a permitir que seu layout oferecesse o acesso ao interior do estande, reclamação histórica dos usuários do programa ao longo de muitos anos, e um dos diferenciais de termos uma equipe experiente a frente do programa - muitos de nós, há anos, participávamos destes eventos - e desse condições técnicas de trabalho aos cooperados, além de permitir tratamentos especiais aos públicos visitantes em cada dia de feira, sendo eles profissionais ou consumidores finais; 
8. A adoção de um sistema on line de reservas que permite acesso amplo e igualitário a todos os agentes do setor, assim como o gerenciamento e acompanhamento das intenções de participação e desenvolvimento do programa de feiras. Este pequeno passo representou o rompimento também com uma prática comum na década de 1990, pois não há mais a possibilidade de interferência de qualquer pessoa na lista de participações nos cooperados brasileiros em feiras.

Esse novo programa de feiras ganhou o nome de Agenda de Promoção Comercial do Turismo Brasileiro no Mercado Internacional, disponibilizado com antecedência no site da Embratur (www.braziltour.comi) e com as inscrições pelo site da

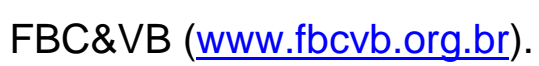

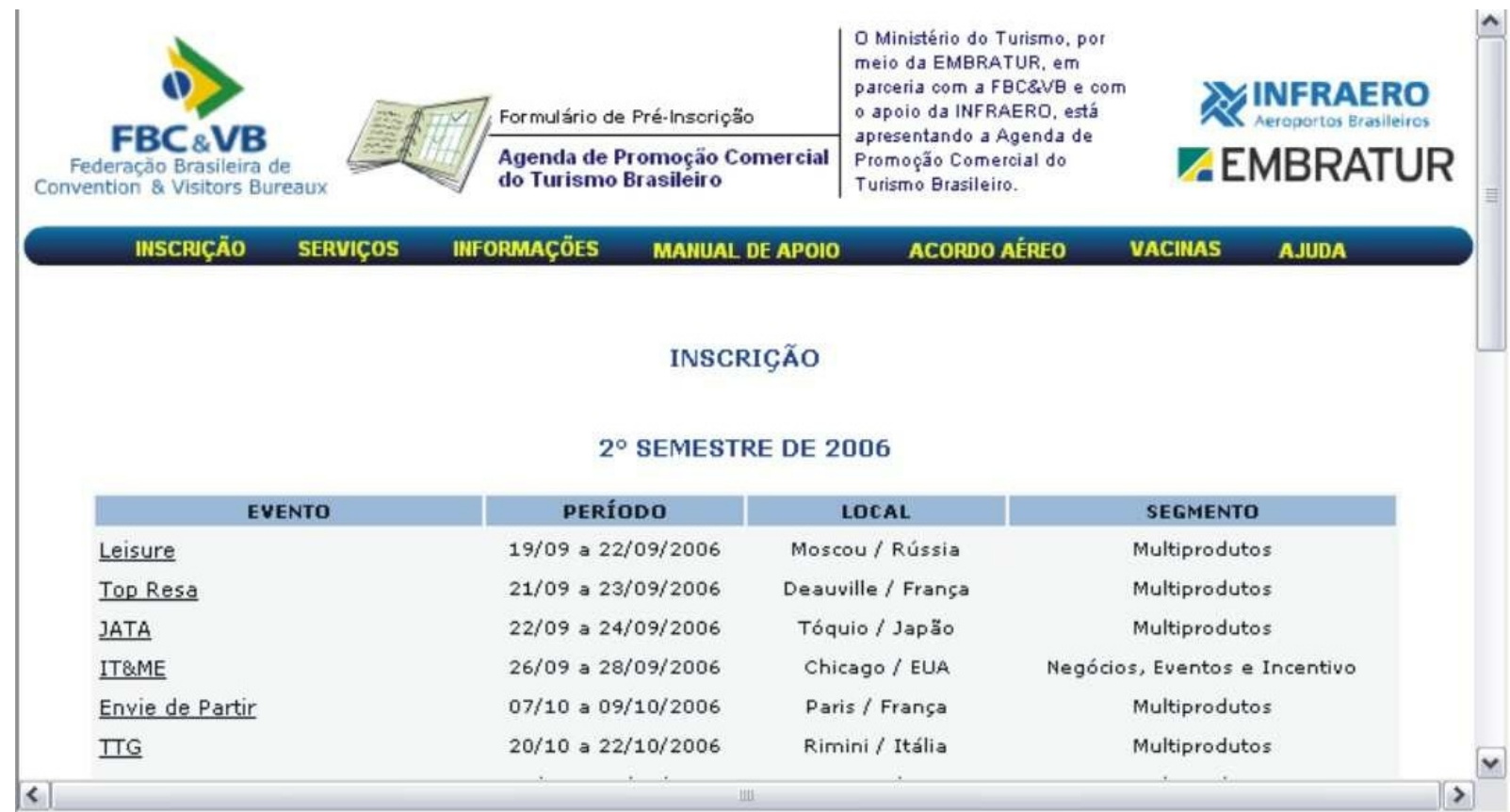

Figura 1 - Site do Programa "Agenda de Promoção Comercial do Turismo Brasileiro no Mercado Internacional"

Com o lançamento e a implantação do Plano Aquarela, a participação nas feiras internacionais tomou um novo formato e é uma ação apresentada com mais qualidade, em decorrência do mapeamento de cada mercado e da adaptação dos estandes aos produtos prioritários em cada mercado. 
Além disso, com o Plano foi possível uma completa remodelação no layout do estande, o que proporcionou maior versatilidade, funcionalidade e mais conforto aos profissionais que participam como co-expositores no espaço brasileiro. Seu novo design, que incorporou traços da cultura brasileira, dá maior visibilidade à marca Brasil como destino turístico, além de permitir uma maior interação entre os co-expositores e os visitantes da feira através de uma melhor projeção e distribuição dos postos de trabalho.

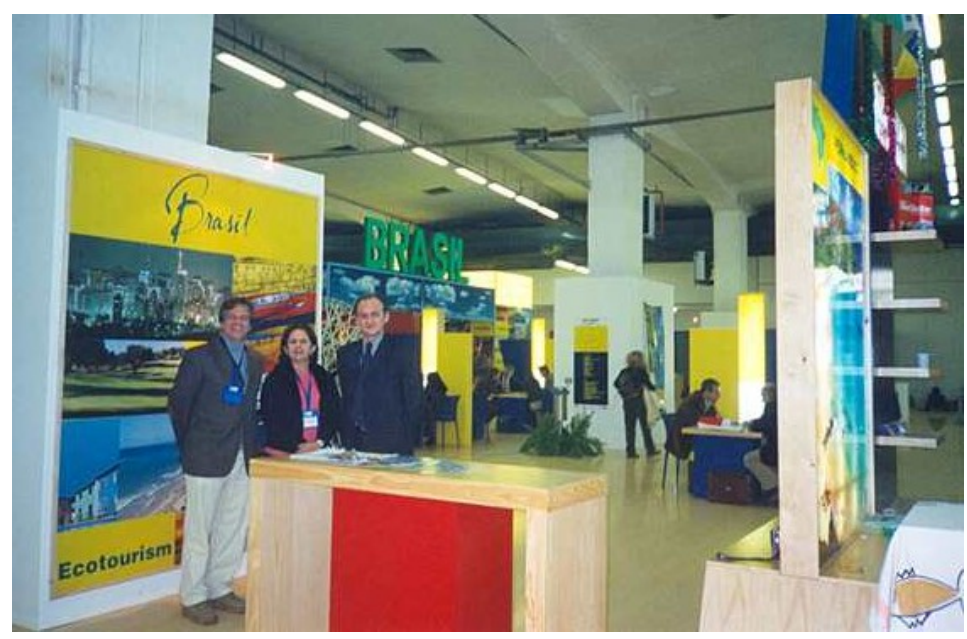

Foto 1 - Pré-Plano Aquarela: Estande no Brasil na Feira BIT

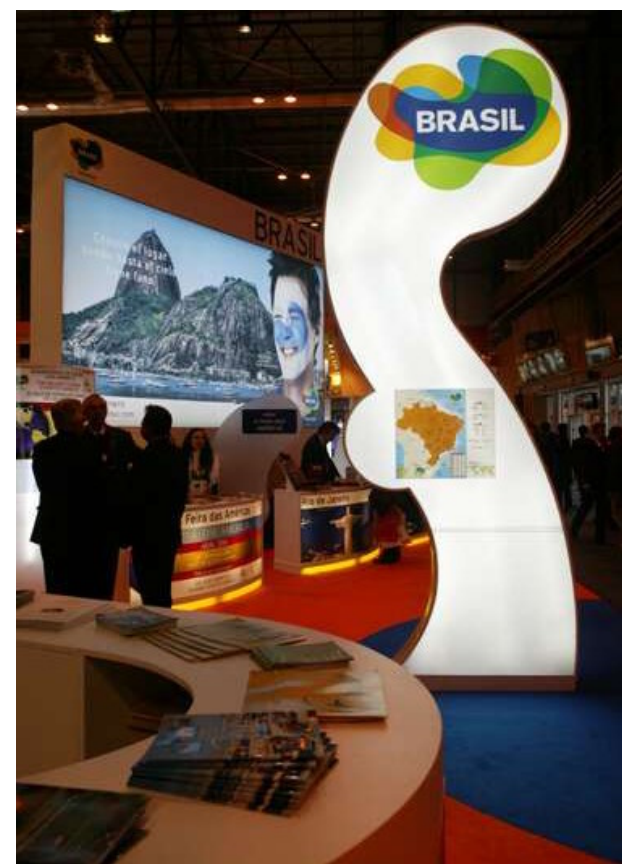

Foto 2 - Pós-Plano Aquarela: Estande do Brasil na Fitur 
Com especial atenção ao turismo cultural, tendo como foco os sítios brasileiros inscritos na lista do Patrimônio Mundial da Unesco - caminho para consolidar uma nova imagem do país, ligada à sua diversidade cultural, natural e humana - completa-se o novo cenário.

Nesse sentido, também foi desenvolvido o programa Noites Brasileiras. Trata-se de um evento cultural, voltado para o mercado e atrelado à agenda de participação do país em feiras consideradas estratégicas. A idéia é reforçar a presença brasileira com elementos da cultura do país, como música, dança e outras manifestações folclóricas. Também podem ocorrer junto aos seminários Descubra o Brasil.

\subsubsection{As dimensões das feiras internacionais}

Dentre as várias definições existentes para as feiras profissionais, de um modo bem simples, pode-se dizer que esse é um meio pelo qual os clientes visitam seus fornecedores. Mas, muito além de ser um local de compra e venda, as feiras abordam aspectos de grande importância, a saber:

\section{A. Comercial:}

Uma feira é um centro de contatos comerciais que permite um grande número de encontros entre fornecedores e compradores, atuais ou potenciais, sobretudo se os compradores são estrangeiros. As feiras acontecem em períodos de lançamento de novos produtos e sempre em momentos que antecedem os períodos de alta temporada.

\section{B. Política:}

Uma feira é o reflexo da importância, criatividade e dinamismo de determinado setor. É importante fator de progresso e atrai personalidades do mundo político, pesquisadores e meios de comunicação. Cenário ideal para fazer novos contatos e 
fortalecer os relacionamentos.

\section{Econômica:}

A participação em feiras internacionais permite o desenvolvimento intenso de contatos comerciais e novos negócios, gerando divisas para o país. Esse fato pode ser visto concretamente no crescimento dos números de entrada de turistas estrangeiros e ingresso de dólares no Brasil nos últimos quatro anos. Resultado desse intenso trabalho de promoção do país no mercado externo.

\section{Tecnológica:}

É um dos principais meios de divulgação e conhecimento das inovações e novas tecnologias, serviços e produtos. Não há forma melhor de se manter atualizado em termos de novidades tecnológicas dentro dos diversos setores da cadeia do turismo.

\section{E. Como Instrumento de Comunicação:}

Nesses eventos, as empresas divulgam seus produtos para um público expressivo e diversificado. É também uma grande oportunidade de acesso à mídia do país em que a feira se realiza e à mídia especializada. Nas feiras há sempre uma presença marcante e em quantidade expressiva de profissionais de comunicação. É, para muitos destinos, assim como para muitos prestadores de serviço, a melhor oportunidade de divulgar o produto e, muitas vezes, obter, a um custo muito baixo, mídia espontânea, ou seja, a uma relação custo-benefício extremamente vantajosa.

Tal trabalho propiciou um atendimento a um número infinitamente maior de empresas co-expositoras, de diferentes segmentos dentro do turismo, a um preço menor e maior oferta de feiras e de espaços em cada uma delas. Veja quadro comparativo:

\section{Participação nas Feiras Internacionais de Turismo}

\begin{tabular}{|l|c|c|c|}
\hline Ano & No. de Feiras & Área $\left(\mathrm{m}^{2}\right)$ & No. de Co-expositores \\
\hline 2002 & 15 & 5.787 & 379 \\
\hline 2003 & 26 & 6.382 & 383 \\
\hline 2004 & 40 & 8.778 & 851 \\
\hline
\end{tabular}




\begin{tabular}{|l|l|l|l|}
\hline 2005 & 40 & 9.136 & 1.152 \\
\hline 2006 & 40 & 6.817 & 1.532 \\
\hline
\end{tabular}

Quadro 1 - Participação nas Feiras Internacionais de Turismo

O registro importante a fazer, para concluir, é que, após cobrir toda a agenda disponível para promoção do Brasil no exterior, praticamente triplicando o número de eventos em que participamos, chega o momento, com o advento de outros programas que começam a somar no sentido de construir uma agenda brasileira de promoção comercial, da diminuição do número de metros quadrados anualmente contratados pela Embratur.

Explica-se isto em decorrência de outra nova constatação que passamos a conceituar e implantar: quem decide a data e local de realização de uma feira comercial é o seu promotor, ou seja, o dono da feira. E este decide de acordo, geralmente, com critérios que levam em conta o mercado em que está atuando, a disponibilidade de áreas e os eventos concorrentes. Nem sempre estes interesses e critérios atendem aos projetos e necessidades do mercado brasileiro. Por isso, por exemplo, participamos da World Travel Market (WTM), em Londres, e não participamos de várias feiras realizadas na China e no Oriente Médio: não há sentido comercial que justifique, por hora, o custo da operação.

Portanto, atingido o volume ótimo deste programa, passamos a desenvolver os outros programas de visibilidade internacional - e esta foi a novidade, a ser narrada adiante - e criar uma agenda cujo processo decisório fosse inteiramente brasileiro, protagonizado pelos agentes econômicos aqui instalados e coordenada pela Embratur. Desta reflexão surgiram os Seminários Descubra o Brasil, as ações de benchmarking e as Caravanas Brasil.

\subsection{Política de Apoio à Captação, Promoção e Realização de Eventos INTERNACIONAIS}

O turismo de negócios e eventos vem sendo consagrado mundialmente como 
um dos mais promissores segmentos do turismo, tendo por agentes principais, empresários, profissionais liberais e funcionários de empresas, cujo objetivo do deslocamento é a celebração de contratos, compra e venda de produtos e serviços, aprendizagem, troca de experiências e de conhecimento. As despesas decorrentes deste deslocamento são encaradas como investimento e com absoluta prioridade para a própria sobrevivência profissional do passageiro em questão, ou da empresa, organização ou instituição a qual pertence.

Por este motivo, estes gastos são, de uma maneira geral, bem mais generosos e mais estáveis do que os gastos com lazer, que sofrem quedas até mesmo abruptas em situações de instabilidade econômica e crises. Segundo a OMT, este valor, relativo ao turista de negócios e eventos praticamente triplica se comparado aos do turista de lazer.

O turismo de negócios e eventos também traz vários outros benefícios:

- desenvolvimento tecnológico e científico, pela maior acessibilidade dos profissionais locais do segmento relacionado ao evento às tecnologias de ponta;

- aumento de investimentos em infra-estrutura e serviços (devido ao alto nível de exigência destes turistas e alta rentabilidade destes negócios);

- geração de emprego e renda;

- redução da sazonalidade quanto à utilização de produtos e serviços no destino de realização do evento (via de regra os negócios e eventos têm sua alta temporada em períodos totalmente diferentes daqueles dedicados a férias);

- e, ainda, ampliação no volume de arrecadação de impostos, já que este tipo de turista necessita de comprovação de despesas para obter ressarcimento das mesmas ou para fins contábeis.

Conceitualmente, o turismo de negócios e eventos compreende, portanto, o conjunto de atividades turísticas decorrentes dos encontros de interesse profissional, associativo, institucional, de caráter comercial, promocional, técnico, científico e social.

O turismo exclusivamente de negócios tem seu foco no profissional que viaja como o intuito de manter contatos com empresas e clientes, por meio de reuniões de caráter corporativo, que nem sempre configuram-se como eventos regulares.

Já o turismo de eventos, como o nome diz, é movido pela participação do turista, 
também na pessoa jurídica, em congressos, encontros, convenções, simpósios, mostras, exposições e feiras. Neste caso, por conta do evento, o volume de pessoas envolvidas, em uma mesma data, é muito maior e obriga a cidade-sede, a oferecer infra-estrutura (de transportes, hoteleira, gastronômica e de compras, basicamente) compatível.

Ciente da relevância deste segmento turístico, a Embratur cria em 2003, na sua reestruturação, dentro da também nova Diretoria de Turismo de Negócios e Eventos, uma gerência específica, focada na atração e acompanhamento de eventos internacionais, denominada Gerência de Turismo de Eventos.

O grande desafio que viria a enfrentar esta nova área era o convencimento das empresas da cadeia produtiva do turismo a atuarem de maneira pró-ativa na captação de eventos e a passar a investir em eventos internacionais, não mais apenas em nacionais.

De um modo geral, o processo de captação de eventos internacionais é bem mais complexo, muito mais oneroso e de maior prazo se comparado aos dos eventos nacionais, embora em termos financeiros, muitas vezes esses últimos possam ser mais rentáveis.

Constatamos ainda que, a exceção dos CVB de São Paulo e Rio de Janeiro, poucos (e os CVBs são os principais agentes pró-ativos desta cadeia) estavam capacitados tecnicamente para gerenciar este processo quando em nível internacional, ao identificarmos:

- deficiência de pessoal com amplo conhecimento do idioma estrangeiro;

- inexistência de material promocional qualificado para competir com destinos internacionais, não havendo material segmentado ou bilíngüe;

- pouca experiência na definição de estratégias de promoção de candidaturas internacionais e principalmente;

- escassez de recursos financeiros e materiais.

Considerando estas dificuldades e com a finalidade de estimular o desenvolvimento das ações de prospecção e promoção desses eventos de maneira sustentável, organizada, democrática e transparente, a Embratur criou, em 2004, uma Política de Apoio à Captação, à Promoção e à Realização de Eventos Internacionais no 
país, gerada dentro da já citada Gerência de Turismo de Eventos, devidamente préaprovada formalmente pela diretoria das entidades que reúnem os agentes mais ativos na captação de eventos: Associação Brasileira de Organizadores de Eventos (Abeoc) Nacional, a FBC\&VB e a Associação Brasileira dos Centros de Eventos e Feiras (Abracef).

Esta política definia alguns elementos fundamentais:

- Os critérios de enquadramento dos eventos internacionais passíveis de apoio;

- A conduta da Embratur em cada etapa do evento;

- Os procedimentos operacionais essenciais para solicitação do apoio;

- As atribuições da Embratur e de seus parceiros;

- Os tipos de apoio que poderiam ser estabelecidos e os critérios de medição de investimento.

Desta forma, qualquer empresa/entidade promotora (ou potencialmente promotora) que possuísse um evento que se enquadrasse nos critérios préestabelecidos, que cumprisse os prazos e os procedimentos operacionais definidos, contaria com o apoio da Embratur e mais, seria atendida por técnicos especializados, com amplos conhecimentos do processo de captação de eventos. Tudo isso sem ônus para o solicitante.

A Embratur passou a viabilizar tanto do ponto de vista financeiro, como, o que é determinante, do ponto de vista técnico, praticamente todos os itens necessários para uma adequada promoção de candidatura e promoção de um evento. Passa a ser efetuada pela nossa equipe, a seguinte relação de atribuições:

- análises dos cadernos de encargos;

- elaboração do projeto e apresentação de candidatura (compilação, organização, criação de materiais impressos e eletrônicos individualizados);

- envio de material promocional (folhetos, cartazes, banners, projetos) diretamente ao local da captação do evento;

- acionamento da embaixada local para solicitação da presença do embaixador na cerimônia de votação;

- aquisição de estandes para promoção da candidatura;

- e até mesmo, se definido entre os parceiros, defesa da candidatura in loco por 
pessoal técnico da Embratur.

Além disso, posteriormente desenvolveu um projeto que viabilizava recursos financeiros para a promoção de eventos internacionais captados - um acordo de cooperação técnica firmado entre Embratur e Abeoc, estendido em 2005 aos CVBs.

Atualmente, as iniciativas de captação internacionais são praticamente na sua totalidade viabilizadas financeiramente pela Embratur. Houve uma inversão da situação de desafio inicial: os custos de captação nacional (que não são passíveis do apoio da Embratur e raramente contam com políticas estaduais e municipais com este enfoque) tornaram-se mais caros aos agentes do que os da captação internacional, o que acaba por promover ainda mais o desenvolvimento das iniciativas.

Somaram-se ainda ações de capacitação dos CVBs, inicialmente promovidas pela Embratur em parceria com a Abeoc, tendo o primeiro seminário, com palestrantes estrangeiros, sido realizado em 2005, no interior de São Paulo, assim como o desenvolvimento de materiais promocionais focados na captação de eventos, utilizando aqueles desenvolvidos pela gerência como referenciais, por meio da verba que a Embratur destina aos estados para utilização em promoção internacional dos destinos.

Os resultados desta ação são impressionantes: de acordo com o ranking dos países do mundo que mais recebem eventos internacionais, publicado pela ICCA, entidade mundial que centraliza e organiza o setor internacionalmente, o Brasil, saindo da 21 a posição em 2002, com 59 eventos registrados, alcançou sucessivamente a 19a

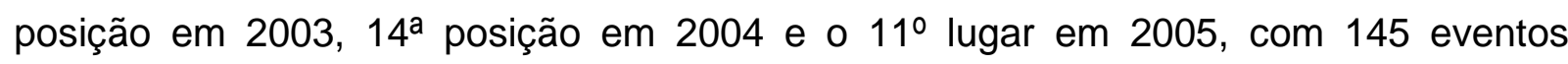
realizados no país, ano em que também, pela primeira vez na história, obteve a 9a colocação entre os países que possuem maior número de participantes em eventos internacionais (o que reflete sua altíssima atratividade turística). Um exemplo eficaz de parceria público-privada. O ranking de 2006, que será divulgado na Imex, de Frankfurt em abril próximo, trará 209 eventos e terá o Brasil, muito provavelmente, conquistando mais posições. 


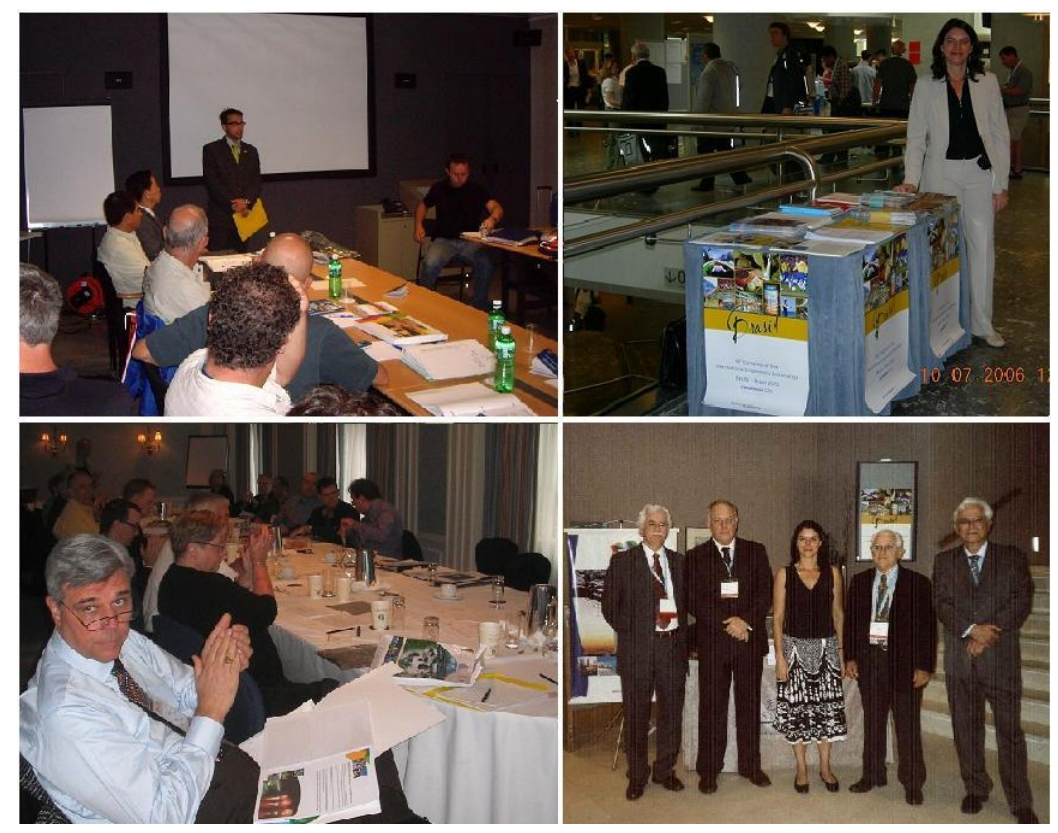

Foto 3 - Apoio à Captação de Eventos Internacionais 2006

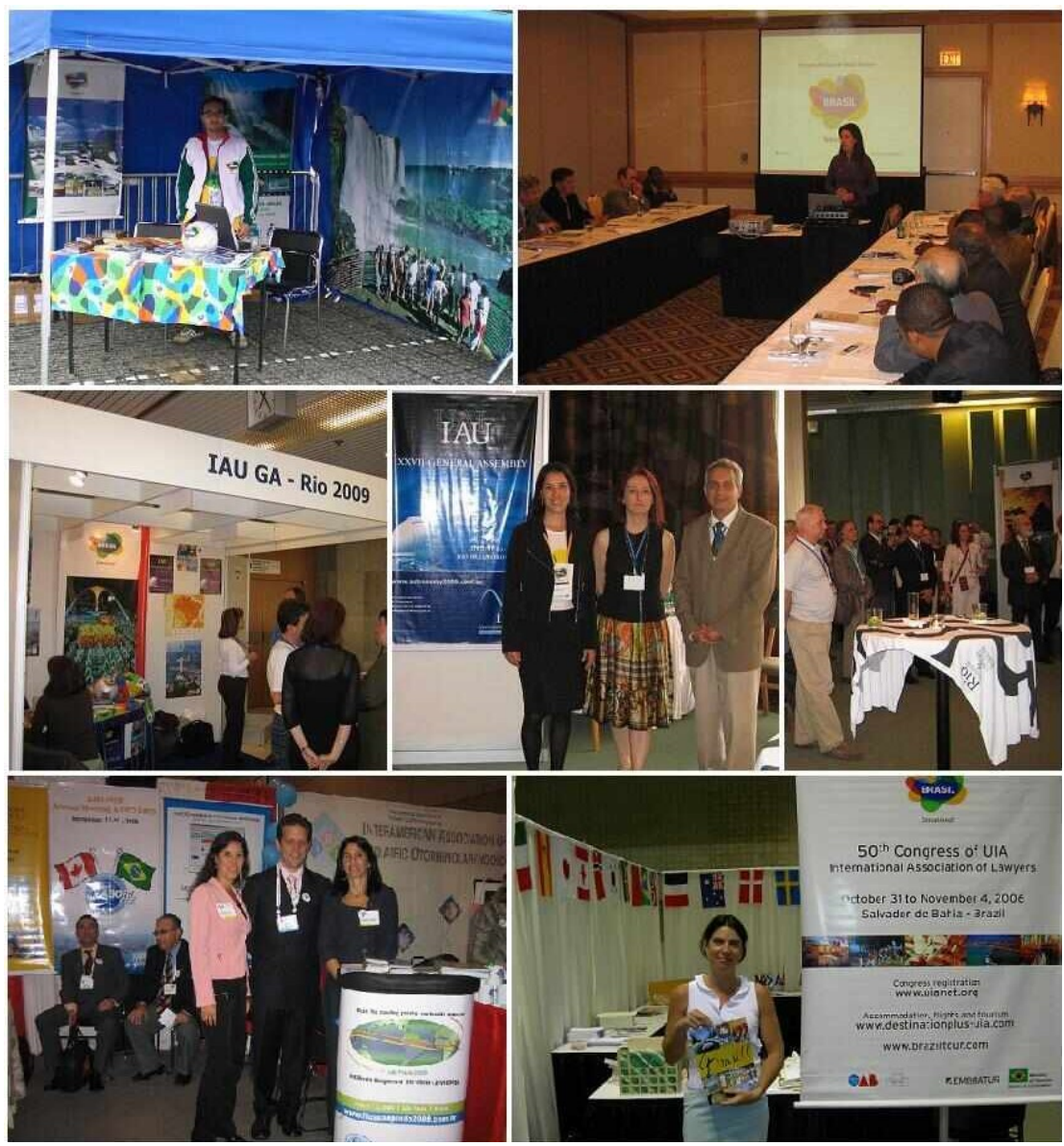

Foto 4 - Apoio à Promoção de Eventos Internacionais - 2006 
Em anexo (Anexo B), está reproduzido documento que a Embratur envia a CVBs e entidades que queiram produzir um bidding book ${ }^{2}$.

\subsection{TURISMO DE NEGócios}

O programa de turismo de negócios não apenas é novo dentro da estrutura da Embratur, mas também na própria agenda de atividades do turismo brasileiro. $O$ objetivo deste programa, cuja gerência é igualmente subordinada à Diretoria de Turismo de Negócios e Eventos, é atrair o turista estrangeiro a negócios, seja para a participação em feiras, eventos corporativos ou quaisquer encontros de caráter comercial, estimulando o seu retorno e o aumento da permanência a lazer, sob a premissa do desenvolvimento econômico do país e, conseqüentemente, do turismo brasileiro.

Detalhamos, abaixo, o programa criado nesse sentido, de divulgação das feiras comerciais brasileiras em eventos dos setores congêneres no exterior, agregada à promoção do Brasil como destino turístico.

Este programa é realizado a partir da triangulação entre a informação recebida da União Brasileira dos Promotores de Feiras (Ubrafe) e a participação em parceria nas feiras em que a Apex-Brasil estiver expondo.

A Ubrafe é a entidade que representa o setor de promoção comercial, nacional e internacionalmente junto a todos os segmentos da nossa economia e nos conselhos de turismo, em seus três níveis. Em seu quadro de associados estão as maiores empresas de promoção e organização de feiras do Sistema Expositor Brasileiro.

Anualmente, as feiras com a marca Ubrafe reúnem cerca de 32 mil expositores nacionais e 6 mil expositores estrangeiros, mais de 100 mil marcas, que atraem um

\footnotetext{
${ }^{2}$ É importante atentar para a temporalidade do texto: quando este documento foi redigido, o programa de ampliação de destinos receptivos para vôos internacionais ainda não havia gerado, no Nordeste, o resultado que acabou por se verificar ao longo de 2005, com a criação dos vôos diretos regulares de Lisboa, via TAP, para Recife, Fortaleza e Natal.
} 
universo de mais de 6,8 milhões de visitantes. Abrangendo os mais variados setores da nossa economia, representam $90 \%$ da ocupação em pavilhões de todos os eventos de promoção comercial, realizados no Brasil.

O primeiro propósito do programa é conjugar os esforços individuais em uma ação conjunta focada na promoção de produtos e serviços do Brasil no território estrangeiro. Para tal, é usado como principal referência o Calendário Ubrafe Principais Feiras de Negócios, com o objetivo principal de promover, em eventos realizados no exterior, as feiras brasileiras que correspondam ao mesmo segmento setor produtivo. Isto provoca o conseqüente aumento da participação dos seguintes tipos de visitantes estrangeiros:

- Compradores;

- Expositores;

- Vendedores de insumos não produzidos no Brasil;

- Mídia especializada;

- Setores governamentais;

- Setores acadêmicos.

Ainda em 2003, em parceria com a Apex-Brasil, a Embratur participa em cinco das principais feiras de negócios internacionais, cobrindo os setores de exportação brasileiros com capacidade de somar-se ao esforço de promoção turística, a saber:

1. Couros \& Calçados;

2. Jóias \& Gemas;

3. Têxteis \& Confecções;

4. Artesanato \& Presentes;

5. Alimentos \& Bebidas.

Em 2004, este programa incorpora mais 5 setores, passando para dez segmentos, sendo eles:

6. Produtos Orgânicos;

7. Horticultura Ornamental (Flores);

8. Rochas Ornamentais (Mármores \& Granitos);

9. Equipamentos Médico-Odonto-Hospitalares;

10. Aviação \& Defesa. 
Entre 2005 e 2006 somam-se mais dois segmentos:

11. Esportes (Equipamento, Vestuário, etc);

12. Música \& Cultura.

Estes mesmo segmentos e atividades passam a ter espaço, subordinados às determinações do Plano Aquarela, nos estandes que a Embratur organiza nas feiras de turismo, por meio de vitrines expostas no estande brasileiro nas feiras onde há interesse pelo turismo de negócios, que são ITB/Berlim, Imex/Frankfurt, FIT/Buenos Aires, WTM/Londres e EIBTM/Barcelona, estimulando encontros comerciais para a compra dos produtos brasileiros in loco.

Nosso esforço para agregar contribuições ao programa capitaneado pela Apex, no desenvolvimento de redes de distribuição e programas de promoção de produtos e serviços brasileiros até então não presentes no mercado internacional, nos possibilitou também iniciar programas de incentivo a novos segmentos do turismo de negócios: turismo de saúde; de educação e ciência; de esportes; de compras; de visitas técnicas (roteiros de negócios) e viagens de incentivo.

É fundamental registrar aqui o papel desempenhado pela Apex do Brasil. Vinculada ao Ministério do Desenvolvimento, Indústria e Comércio Exterior (MDIC), seus programas são os principais responsáveis pelo fato de o Brasil ter duplicado o volume de exportações nestes quatro anos, ampliando não apenas a pauta de produtos e serviços, como também gerando em conseqüência uma interiorização de desenvolvimento econômico, pela inserção de produtores, em cidades que jamais haviam vivido este processo, na cadeia de exportação. Quando este movimento começa a gerar visitação, por parte de compradores, técnicos, profissionais de mídia e pesquisadores, a destinos fora do eixo Rio-São Paulo, nosso trabalho também se reforça.

Abaixo estão listados os eventos que inserimos no programa já em 2003, com os respectivos setores:

- JA New York - Nova York, EUA (Jóias \& Gemas);

- GDS - Dusseldorf, Alemanha (Couros \& Calçados);

- Anuga - Colônia, Alemanha (Alimentos \& Bebidas);

- Semana Brasileira em Dubai - Brazilian Week \& Trade Exhibition (BWTE) - 
Emirados Árabes (evento organizado pela Apex por ocasião da Missão Presidencial). Eventos inseridos no programa com a ampliação ocorrida em 2004:

A. No exterior:

1. ITB - Berlim, Alemanha (Multiprodutos);

2. Imex - Frankfurt, Alemanha (Negócios e Incentivo);

3. Missão Presidencial à China - Pequim e Xangai, China (Missão organizada pelo Itamaraty);

4. The JCK Show - Las Vegas, EUA (Jóias \& Gemas);

5. Farnborough - Londres, Inglaterra (Aviação \& Defesa);

6. NBTA - National Business Travel Association - Orlando, EUA (Negócios e Incentivo);

7. Expo Brasil China - Beijing, China (Multiprodutos);

8. Lyon Mode City - Lyon, França (Têxteis \& Confecções);

9. Leisure - Moscou, Rússia (Multiprodutos);

10. Moda Brasil na Rússia - Moscou, Rússia (têxteis \& confecções) - Missão empresarial organizada pela Apex;

11. SANA - Bolonha, Itália (Produtos Orgânicos);

12. AUTOMECHANIKA - Frankfurt, Alemanha (Equipamentos Mecânicos);

13. GDS - Dusseldorf, Alemanha (Couro \& Calçados);

14. Expo Mundial de Turismo - Cidade do México, México (Multiprodutos);

15. Marmomacc - Verona, Itália (Mármores \& Granitos);

16. SIAL - Paris, França (Alimentos e Bebidas);

17. SAITEX - Joanesburgo, África do Sul (Multiprodutos);

18. EIBTM - Barcelona, Espanha (Negócios e Incentivo);

19. Médica - Dusseldorf, Alemanha (Produtos Médico-Odonto-Hospitalares).

B. No Brasil:

1. Rio Fashion - Rio de Janeiro;

2. Unctad XI - São Paulo;

3. Ubrafe - São Paulo;

4. Brite - Rio de Janeiro;

5. Lacime - São Paulo; 
6. BNTM - Salvador, BA;

7. Labace - São Paulo;

8. Seminário ICCA - São Paulo;

9. Francal - São Paulo;

10. Fispal/Recife - Recife PE.

A agenda é novamente ampliada em 2005, com a inserção dos seguintes eventos:

A. No exterior:

1. World Travel Fair (WTF) - Xangai, China (Multiprodutos);

2. Biofach - Nuremberg, Alemanha (Produtos Orgânicos);

3. Anato - Bogotá, Colômbia (Multiprodutos);

4. Texworld - Paris, França (Têxteis \& Confecções);

5. TUR - Gotemburgo, Suécia (Multiproduto);

6. Fispal Latino - Miami, EUA (Alimentos \& Bebidas);

7. NRA - Chicago, EUA (Alimentos \& Bebidas);

8. Missão Presidencial à Coréia do Sul e ao Japão (a Embratur coordenou a participação do workshop de turismo em Tóquio, Japão - não participamos na Coréia do Sul);

9. Le Bourget - Paris, França (Aviação \& Defesa);

10. Show Room de Calçados Brasileiros no Chile - Santiago, Chile (Couro \& Calçados);

11. Tendence Lifestyle - Frankfurt, Alemanha (Artesanato \& Presentes);

12. Salão de Lyon - Lyon, França (Têxteis \& Confecções);

13. Marmomacc - Verona, Itália (Mármores \& Granitos);

14. Jany - New York, EUA (Jóias \& Gemas);

15. Achmart - Santiago, Chile (Multiprodutos);

16. Jata - Tokyo, Japão.

B. No Brasil:

1. Vitória Stone Fair - Vitória, ES (Mármores e Granitos);

2. Destinations Brasil - Rio de Janeiro, RJ (Negócios e Incentivo);

3. BNTM - Fortaleza, CE (Bolsa de Turismo do Nordeste); 
4. Abav - Rio de Janeiro, RJ (Multiprodutos).

Em 2006, após avaliação de resultados obtidos ao longo dos anos anteriores, com a inclusão e retirada de vários eventos, a agenda de promoção do Brasil, no segmento de turismo de negócios, foi a seguinte:

A. No exterior:

1. Colombiatex - Medellín, Colômbia (Têxteis \& Confecções);

2. Projeto Vendedor Artesanato - Frankfurt, Alemanha (Artesanato);

3. NRA - Chicago, EUA (Alimentos \& Bebidas);

4. JCK - Las Vegas, EUA (Gemas \& Jóias);

5. Show Room de Calçados - Santiago, Chile (Couro \& Calçados);

6. Projeto Moda Brasil na Itália - Milão, Itália (Têxtil e Confecções);

7. Encontro Econômico Brasil Alemanha - Berlim, Alemanha;

8. Farnbourough International Air Show - Londres, Inglaterra (Aviação \& Defesa);

9. Ispo Summer - Munique, Alemanha (Têxtil \& Confecções de Artigos Esportivos);

10. JA New York - New York, EUA (Gemas \& Jóias);

11. Tendence Lifestyle - Frankfurt, Alemanha (Artesanato \& Presentes);

12. Simm - Madri, Espanha (Têxteis \& Confecções);

13. Lyon Mode City - Lyon, França (Têxteis \& Confecções);

14. GDS - Düsseldorf, Alemanha (Couro \& Calçados);

15. Automechanika - Frankfurt, Alemanha (Autopeças);

16. Texworld - Paris, França (Têxteis \& Confecções);

17. Popkomm - Berlim, Alemanha (Música);

18. Marmomacc - Verona, Itália (Mármores \& Granitos);

19. Sial - Paris, França (Alimentos \& Bebidas);

20. Médica - Düsseldorf, Alemanha Equipamentos Médico-Odonto-Hospitalares);

21. Seminário Ubrafe - Argentina;

22. Seminário Ubrafe - Chile.

B. No Brasil:

1. Fórum Panrotas - São Paulo, SP;

2. Seminário Jica-Mercosul - na Braztoa - São Paulo, SP;

3. Salão Profissional do Turismo - São Paulo, SP; 
4. Francal 2006 - São Paulo, SP;

5. Abav - Rio de Janeiro, RJ;

6. Jornada dos 40 Anos Embratur;

7. Encontro Comercial Braztoa - São Paulo, SP.

Um comentário importante a respeito deste programa é relativo ao grau de dificuldade encontrado para sua implantação, principalmente se comparado aos outros dois vetores que compõem, com este terceiro, o conjunto de ações conduzidas pela Embratur para que o Brasil iniciasse um processo de inserção no tema Turismo de Negócios e Eventos a partir de 2003. Esta dificuldade se deve basicamente ao fato de que:

a. enquanto o programa de participação em feiras, apesar da fragilidade com que era conduzido anteriormente, tinha uma massa crítica de envolvidos, e

b. o programa de captação de eventos contava com interlocutores nos CVBs que, ainda que não dispondo de história internacional, estavam absolutamente dispostos a percorrer os caminhos necessários para tanto,

este novo programa de turismo de negócios sofria com a dificuldade gerada pela inexistência de uma história produtiva de interlocução entre os promotores de feiras e a Embratur.

Isto se explica com certa facilidade: a história de relacionamento entre estes promotores e as entidades e organismos de promoção internacional do país - e aí novamente vale a tese de que este investimento sempre é protagonizado por recursos federais, pois se trata basicamente de Itamaraty e Apex, e posteriormente de Embratur - não é uma história de muito sucesso. Apesar de momentos muito interessantes vividos pelo setor de feiras ao longo desses anos todos, há uma divergência insuperável de conceitos entre estes agentes econômicos: enquanto os promotores defendem que os recursos federais de promoção devem ser destinados aos eventos portanto gerenciados pelos próprios promotores - organizações como a Apex destinam recursos, até por determinação legal, a entidades representativas de setores econômicos.

Esta divergência de opções, não superada até o presente momento, impactou negativamente o início do programa gerenciado pela Embratur, que entrava neste 
processo em 2003, sem nenhuma relação com a história anterior. Na realidade, o programa da Embratur, por ser o que mais se aproxima da reivindicação deste segmento, na medida em que promove no exterior as feiras realizadas no Brasil, acaba por se credenciar como eficaz perante o mercado, mas suas dimensões ainda estão por mostrar-se na plenitude.

Ainda quanto ao tema Turismo de Negócios e Eventos, vale retomar um comentário do início deste trabalho: a história de promoção do turismo brasileiro no exterior, além de instável e errática, nos poucos momentos em que ganhou alguma consistência em volume, foi marcada pelo binômio recursos naturais e lazer. Este binômio, além de remontar à tristemente histórica Festa de Rouen, já tinha sua morte anunciada, enquanto instrumento capaz de ampliar e protagonizar o desenvolvimento consistente de destinos turísticos há pelo menos duas décadas. Credito parte importante dos expressivos resultados e dos sucessivos recordes, tanto em volume de passageiros estrangeiros como em ingresso de moeda estrangeira, a esta opção que tomamos logo ao início do programa: criar finalmente neste País um programa para disputar mercado internacional, neste segmento. 


\section{APOIO À COMERCIALIZAÇÃO}

\subsection{BUREaUX DE Comercialização}

Uma das estratégias da Embratur, tendo por objetivo ampliar os canais de distribuição dos produtos turísticos brasileiros no exterior, e ao mesmo tempo, fomentar a organização dos segmentos do mercado turístico em entidades representativas, foi a criação dos Bureaux de Comercialização.

Esta estratégia nasceu da constatação de que, sem estes Bureaux, seria impossível superar um dilema que atrasava há décadas as ações de promoção: não havia instrumento, sob a égide da legislação que regula as ações de investimento com recursos federais, que nos permitisse inserir os agentes econômicos, por meio de seus produtos e serviços, nos materiais promocionais. E nada mais ineficaz que as belas fotos que o Brasil usava antigamente, com paisagens lindas, e slogans bem elaborados, mas que não traziam um instrumento sequer - telefone, site, endereço que permitisse ao público, fossem profissionais, fossem consumidores finais, acessar os destinos ou produtos promovidos.

Com base na experiência dos CVBs, já narrada no capítulo anterior, lançamos o programa dos Bureaux de Comercialização, que nada mais são do que uma organização que reúne, sob a bandeira da promoção internacional, empresas que, no mercado local, concorrem entre si.

Essas organizações passam a atuar como parceiras da Embratur na conquista do mercado internacional, por serem entidades de direito privado, sem fins lucrativos e de interesse público, controladas em sua maioria por operadoras de turismo, capazes de multiplicar resultados obtidos no mercado externo junto às comunidades, organizações e membros da cadeia produtiva local.

Consolidadas as parcerias, estas empresas, por meio de seus representantes eleitos, configurando um Bureau, definem em conjunto com a Embratur uma agenda de participações em feiras, eventos e missões internacionais, pois junto à promoção e 
divulgação dos produtos brasileiros também são realizados negócios entre os agentes do mercado. Começávamos aqui a criar mais um novo processo de superação de práticas já desgastadas: os Bureaux e suas agendas, somados a outras iniciativas que ainda serão descritas aqui, conformam uma agenda brasileira de promoção, começando a deixar para trás o período em que a única atuação do país no exterior eram a participação em 15 feiras anuais.

Além da missão de conquistar o mercado externo, internamente os Bureaux são responsáveis pela orientação conceitual, padronização de conduta e instrução dos seus associados para que o serviço prestado dentro do seu segmento seja de alta qualidade. Até junho de 2006, cinco Bureaux encontravam-se em operação:

- Bureau Nacional de Turismo de Golfe (convênio assinado em 11/2003);

- Bureau Brasileiro de Pesca Esportiva (convênio assinado em 04/2005);

- Bureau Brasileiro de Resorts (convênio assinado em 08/2003);

- Bureau Brasil de Ecoturismo (convênio assinado em 09/2005 );

- Bureau Brasileiro de Intercâmbio (convênio assinado em 05/2005).

A partir de agora, a criação de novos Bureaux deve ser iniciativa do trade específico, que pode ser fomentado por ações da Embratur. Entre as estratégias utilizadas para tal, está o agendamento de reuniões específicas entre agentes e órgãos do Governo Federal, Estadual ou Municipal, além da participação em eventos para explicações a respeito das ações promocionais da Embratur em conjunto com seus parceiros.

Outras ações dos Bureaux são viagens, realizadas com auxílio da Embratur e de seus EBTs no exterior, a determinados países-alvo com o objetivo de realizar reuniões com o trade local, além de palestras informativas, workshops de capacitação, rodadas de negócio e participação em feiras internacionais, caso haja coincidência de datas.

Cada Bureau, em conjunto com a Embratur, prepara um material de treinamento (apostilas, apresentações multimídia) que é apresentado a toda uma cadeia produtiva de determinada região. Para tal apresentação, os Bureaux convidam operadores de turismo, imprensa, representantes governamentais, de entidades representativas, membros do trade específico e possíveis parceiros que possam vir a ajudar no aumento e na qualificação da oferta de produtos do segmento. 
O representante do Bureau responsável pela missão já deixa o Brasil com as ações pré-agendadas. Para tal, conta com o auxílio dos EBTs em cada mercado prioritário, que auxilia também na preparação das rodadas de negócio e workshops.

Entrando já em seu quarto ano de funcionamento, este programa, somado aos que serão descritos a seguir, trazendo em seu bojo como comentei, a criação, finalmente, de uma agenda brasileira de promoção turística, explicita outro conceito importante de nosso programa e demarca-se outro rompimento com uma prática tradicional e limitada dos anos 1990: enquanto que anteriormente o Brasil se limitava a participar em feiras, o que é fundamental, mas insuficiente - e já tratei destas limitações no item anterior - com os Bureaux de comercialização, os seminários, os treinamentos de agentes de viagem e outras ações junto aos canais de distribuição, colocamos a agenda integralmente sob o controle das demandas do mercado brasileiro.

A partir deste momento, tem-se um processo de nova qualidade em nossa promoção, pois o segundo momento do programa, vivenciado a partir do final de 2005, foi a atuação coordenada de dois ou mais Bureaux em um mesmo mercado, agregado a atividades dos EBTs, Seminários e assim por diante, sob a orientação da Embratur. Está próximo o dia em que o Brasil vai dar o terceiro passo: ao lado do programa de feiras, que terá cada vez mais um caráter institucional, vamos ampliar estes novos programas, para criar uma agenda de caráter comercial exclusivamente brasileira, multi-produtos, regular e perene.

Resumo de Ações e Resultados dos Bureaux de Comercialização (até set./2006)

$\begin{array}{lr}\text { Feiras Internacionais } & 18 \\ \text { Missões Comerciais } & 8 \\ \text { Workshops Internacionais } & 19 \\ \text { Treinamentos Trade } & 9 \\ \text { Fam Trips } & 2\end{array}$

Quadro 2 - Resumo de Ações e Resultados dos Bureaux de Comercialização 


\subsection{Seminários Descubra o Brasil, Treinamento de Agentes de Viagens e Apoio a EVENTOS}

O segundo programa da Diretoria de Turismo de Lazer e Incentivo foi a implantação, em 2004, do Sistema de Promoção Comercial do Produto Turístico Brasileiro no Mercado Internacional.

Conceitualmente, o objetivo principal do sistema de promoção comercial é identificar mercados, criar oportunidades e estabelecer estratégias para promover os produtos turísticos brasileiros no mercado internacional, proporcionando o incremento de negócios através do aumento do fluxo turístico qualificado com destino ao Brasil, bem como a geração de renda e novos postos de trabalho.

O sistema contempla duas vertentes: a primeira diz respeito aos aspectos de inteligência comercial, que foram sendo identificados através de estudos e práticas de mercado, relatórios de conjuntura, análise de mercados competidores, identificação de oportunidades de negócios e pesquisas primárias e secundárias para balizamento de dados existentes.

Já a segunda refere-se ao apoio à comercialização do produto turístico brasileiro no mercado internacional, sobretudo naqueles países onde estão instalados os escritórios de turismo, com identificação de operadoras, agências de viagens, jornalistas especializados, veículos de comunicação efetivos, participação em entidades de turismo locais, elaboração de base de dados, avaliação das ações implementadas e realização de eventos (seminários, treinamentos, apoio a eventos, Caravana Brasil e press trip).

Com base nestas premissas, lançamos os programas que se seguem.

\subsubsection{Seminário Descubra o Brasil}

São eventos realizados nos mercados prioritários, definidos pelo Plano Aquarela, 
ou em mercados potenciais. Os objetivos principais: ampliar o número de operadores que comercializam o produto brasileiro e o número de destinos brasileiros comercializados, bem como qualificar a informação acerca dos produtos e destinos turísticos brasileiros. Temos como compradores, os operadores destes mercados-alvos e como expositores, os operadores de receptivo brasileiros e promotores institucionais do Brasil, como governos estaduais e municipais. São convidadas também companhias aéreas que fazem a ligação destes destinos com o Brasil.

O formato ideal finalmente acordado para este evento tem sido a apresentação de vídeo/power point sobre os segmentos e alguns destinos turísticos brasileiros apontados pelo Plano Aquarela, de forma descontraída, em que o objetivo principal é passar informações gerais sobre o Brasil e aquecer o ambiente para o momento seguinte, que é a rodada de negócios. Essa fase dura no máximo 60 minutos e, na apresentação, são utilizadas muitas imagens, fotos e é realizado sorteio de brindes.

O ambiente para a rodada de negócios sempre é montado em sala próxima a fim de facilitar a circulação e garantir a privacidade em cada mesa para as negociações. Esta etapa estende-se no máximo por três horas. No encerramento, sempre oferecemos coquetel acompanhado, de preferência, de apresentação de música e danças típicas do Brasil.

O principal papel dos EBTs nesse tipo de evento, é a indicação e escolha do local e do horário mais adequados, além da seleção criteriosa dos operadorescompradores. As demais providências devem estar a cargo de uma empresa organizadora de eventos com experiência de atuação no mercado a ser realizado o Seminário.

Dados dos Seminários Descubra o Brasil

\begin{tabular}{|c|c|c|c|c|}
\hline ANO & SEMINÁRIO & LOCAL & DATA & $\begin{array}{c}\text { No. DE BUYERS } \\
\text { (operador + imprensa } \\
- \text { no. de pessoas) }\end{array}$ \\
\hline $2004^{*}$ & INGLATERRA & Londres & $23 / 09$ & 80 \\
\hline & FRANÇA & Paris & $05 / 11$ & 164 \\
\hline $2005^{\star}$ & FRANÇA & Paris & $09 / 11$ & 175 \\
\hline & ESTADOS UNIDOS & Nova York & $22 / 11$ & 200 \\
\hline & ESPANHA & Madri & $02 / 12$ & 40 \\
\hline & ALEMANHA & Frankfurt & $06 / 12$ & 82 \\
\hline
\end{tabular}




\begin{tabular}{|c|c|c|c|c|}
\hline 2006 & ALEMANHA & Frankfurt & $14 / 03$ & 7 \\
\hline & RÚSSIA & Moscou & $16 / 03$ & 54 \\
\hline & SUÉCIA & Estocolmo & $21 / 03$ & 35 \\
\hline & ITÁLIA & Bergamo & $24 / 03$ & 29 \\
\hline & ESPANHA & Madri & $04 / 04$ & 54 \\
\hline & INGLATERRA & Londres & $11 / 04$ & 66 \\
\hline & MÉXICO & Cidade do México & $09 / 05$ & 113 \\
\hline & CANADÁ & Montreal & $11 / 05$ & 123 \\
\hline & CANADÁ & Toronto & $12 / 05$ & 94 \\
\hline & ESTADOS UNIDOS & Atlanta & $15 / 05$ & 78 \\
\hline & ESTADOS UNIDOS & Dallas & $16 / 05$ & 26 \\
\hline & FRANÇA & Paris & $18 / 05$ & 90 \\
\hline & ARGENTINA & Córdoba & 12 e $13 / 06$ & 205 \\
\hline & CHILE & Santiago & $20 / 06$ & 213 \\
\hline & URUGUAI & Montevidéu & $22 / 06$ & 116 \\
\hline & COLÔMBIA & Bogotá & 25 e $26 / 08$ & 146 \\
\hline
\end{tabular}

* Nos convidados dos anos de 2004 e 2005 não foi considerado o número de jornalistas presentes nos Seminários, apenas operadores.

Quadro 3 - Dados dos Seminários Descubra o Brasil

\section{Dados Resumidos}

\begin{tabular}{|c|c|c|c|}
\hline ANO & №. SEMINÁRIOS & №. PAÍSES & TOTAL DE PARTICIPANTES \\
\hline 2004 & 2 & 2 & 244 \\
\hline 2005 & 4 & 4 & 497 \\
\hline 2006 & 16 & 14 & 1449 \\
\hline TOTAL & 22 & 15 & 2190 \\
\hline
\end{tabular}

Quadro 4 - Dados Resumidos

Dados por País

\begin{tabular}{|c|c|c|c|}
\hline & PAíS & No. DE SEMINÁRIOS & TOTAL DE PARTICIPANTES \\
\hline 1 & ALEMANHA & 2 & 122 \\
\hline 2 & ARGENTINA & 1 & 205 \\
\hline 3 & CANADÁ & 2 & 217 \\
\hline 4 & CHILE & 1 & 213 \\
\hline 5 & ESPANHA & 2 & 94 \\
\hline 6 & ESTADOS UNIDOS & 3 & 304 \\
\hline 7 & FRANÇA & 3 & 429 \\
\hline 8 & INGLATERRA & 2 & 146 \\
\hline 9 & ITÁLIA & 1 & 29 \\
\hline 10 & MÉXICO & 1 & 113 \\
\hline 11 & RÚSSIA & 1 & 54 \\
\hline 12 & SUÉCIA & 1 & 35 \\
\hline 13 & URUGUAI & 1 & 116 \\
\hline 14 & COLÔMBIA & 1 & 146 \\
\hline
\end{tabular}

Quadro 5 - Dados por País 


\subsubsection{Treinamento de Agente de Viagens}

São eventos realizados na área de atuação dos EBTs e têm como objetivo principal o auxílio na distribuição dos produtos turísticos brasileiros, por meio de apoio aos operadores para a apresentação desses produtos à sua rede de agentes de viagem. Este é também um instrumento importante para levar os produtos brasileiros às cidades mais distantes dos mercados prioritários, onde normalmente a promoção não é feita de forma estruturada e planejada.

O formato ideal desse evento é a apresentação dos segmentos e destinos brasileiros para os agentes de viagem, feita pelo próprio executivo do EBT, seguida de outra feita por operadores que já comercializam o Brasil naquele mercado. Essas apresentações duram no máximo duas horas e podem ser finalizadas com um coquetel. Este é um tipo de evento que, em função do seu orçamento reduzido, pode ser feito em diversas cidades, ampliando o leque de distribuição da informação. Toda a estrutura do evento é operacionalizado pelo executivo do EBT.

\subsubsection{Apoio a Eventos}

São eventos realizados em parceria com empresas, nos mercados prioritários, e têm dois formatos e objetivos distintos:

1. Evento em parceria com operador, auxiliando na distribuição de seus produtos para sua rede de contatos naquele mercado. Toda a responsabilidade de organização e de seleção dos agentes é do operador, ficando o EBT apenas responsável pela apresentação institucional. Geralmente existe apoio financeiro para realização de um coquetel. Este é um instrumento importante de relacionamento com os operadores que já vendem o Brasil e muito adequado também para estados e municípios.

2. Apoio a empresas para exposição junto ao público final do destino, geralmente 
feitos com galerias de arte, rede de lojas, supermercados e empresas que trabalham com comercialização de produtos brasileiros. Aqui, a parceria Embratur-Apex tem sido o destaque, com menção especial às atividades desenvolvidas na Inglaterra em 2004, na França e no Oriente Médio em 2005, e na Alemanha em 2006.

As ações praticadas, em sua grande maioria, não são novas quanto ao seu formato, porém apresentam diferenças quanto a sua abordagem, sistematização e operacionalização. A novidade reside no fato de que a escolha das ações se dá em função dos mercados prioritários, do tipo de público, das ações complementares realizadas em cada país e também do interesse dos parceiros na realização das ações, tais como estados, entidades (como FBCVB, Braztoa e Bito) e companhias aéreas, entre outros.

Os resultados apresentados até o momento, decorridos quase dois anos da apresentação da nova imagem do Brasil no exterior, têm demonstrado o acerto nesses tipos de ações. Novos operadores, jornalistas especializados e agências de turismo têm participado, iniciado ou incrementado o processo de comercialização do produto turístico brasileiro. Em todas as apresentações, percebe-se a participação de grandes players dos mercados em questão.

Esse processo tende a aproximar e estabelecer relações de confiança junto aos operadores estrangeiros. Porém, cabe destacar que não se trata de um processo isolado; está amplamente integrado com as demais ações desenvolvidas pela Embratur, tais como: feiras, captação de eventos, caravanas, escritórios, relações públicas e marketing, e aí gera uma nova conseqüência: a fidelização de operadores e demais parceiros do trade internacional.

\subsubsection{Treinamento On Line}

Os programas de apoio à comercialização chegaram à sua nova geração com a inserção de tecnologias consagradas pelo mercado no cotidiano da Embratur. $\mathrm{O}$ treinamento de agentes de viagem não é uma criação brasileira, ao contrário, é uma 
das atividades que nossos profissionais, vivenciados na disputa de mercado, conheceram como convidados de operadoras nas quais trabalharam, ou de destinos que promoveram. Nossa decisão de implantar o programa ocorreu após constatarmos que, embora estivéssemos ampliando a inserção do Brasil em todas as áreas possíveis de se envolverem na comercialização de produtos e serviços brasileiros, estávamos esbarrando em um limite muito objetivo: o profissional que está na ponta da linha, no atendimento direto ao consumidor, não estava preparado para vender estes produtos e serviços aos seus clientes. $E$ isto se dava por razões bastante objetivas: com um cotidiano geralmente marcado por ganhos fixos pequenos e comissões por volume de vendas, estes profissionais, majoritariamente jovens, tendem a buscar uma venda mais rápida e fácil, portanto ligada a produtos que conhecem.

Ora, tendo iniciado este programa com treinamentos presenciais, observamos a reação rápida e positiva do mercado a eles. Junto a centenas de agencias de viagem, não apenas nos mercados principais definidos pelo Plano Aquarela, mas também nos mercados secundários, atendidos pelos EBTs ou não, começam a surgir demandas por treinamento e capacitação. A partir de um certo momento, nossa estrutura passou a viver um agradável problema: não dispúnhamos mais de capacidade física para atender a demanda que não parava de crescer. Neste momento, a opção por passarmos a utilizar um sistema que já vinha sendo praticado com sucesso por várias instituições educacionais do país, com sucesso, o treinamento on-line, apresentou-se como solução extremamente adequada.

Juntamente com a Fundação Getulio Vargas (FGV), desenvolvemos um sistema muito bonito, amigável, em vários idiomas, utilizável e atualizável via internet, para treinar agentes de viagem em:

- como informar a clientes e a si próprios sobre o Brasil;

- como desenvolver e promover roteiros e produtos brasileiros junto a seus clientes;

- como participar da agenda de promoção do país.

Lançado em setembro de 2006, envolvendo no primeiro momento os agentes de viagem de Espanha, Portugal, Estados Unidos, Chile , Colômbia e Peru, o programa teve 710 inscritos nestes 6 países. Conta com 5 módulos, sendo 3 de conteúdo, todos baseados no Plano Aquarela, somados a um de apresentação e um de avaliação final. 


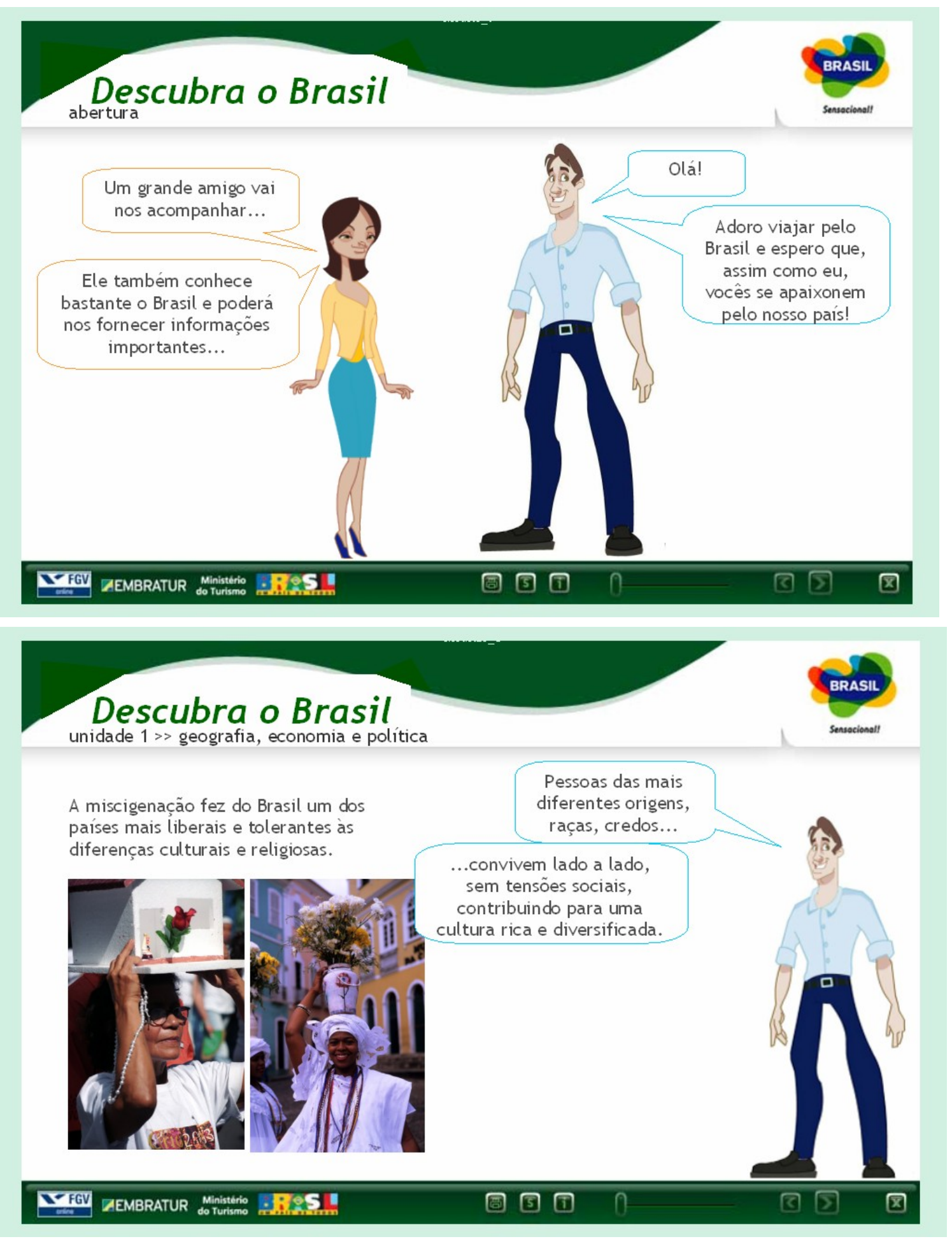




\section{Descubra o Brasil}

unidade $1 \gg$ geografia, economia e política

A maior parte dos quase $\mathbf{1 6}$ mil $\mathbf{~ K m}$ de fronteiras terrestres com 10 vizinhos sul-americanos - encontra-se desabitada, dadas as condições históricas de ocupação da América do Sul.

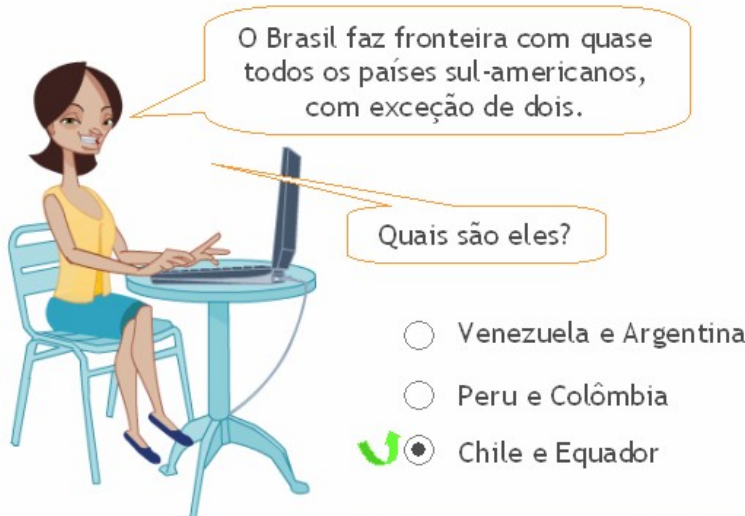

Os vizinhos sul-americanos do Brasil são...

- Guiana Francesa;

- Suriname;

- Guiana;

- Venezuela;

- Colômbia;

- Peru;

- Bolívia;

- Paraguai;

- Argentina

- Uruguai.

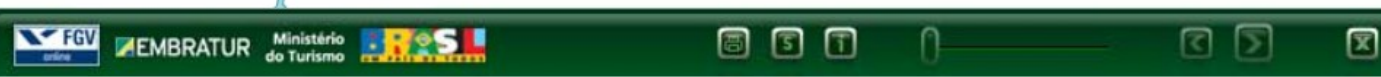

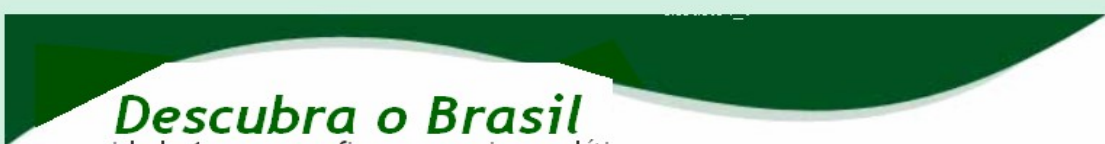

unidade 1 > geografia, economia e política

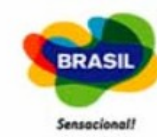

\section{Região Sul}

Menor região brasileira e a única de clima temperado, o que faz com que as quatro estações climáticas sejam bem definidas.

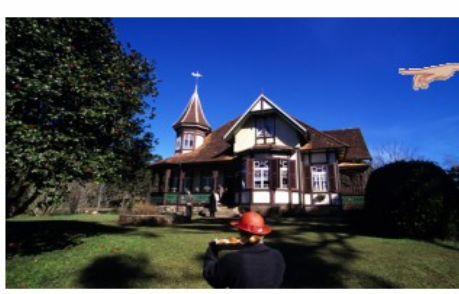

Clique na imagem para vê-la ampliada.

A Região Sul apresenta grande influência da imigração européia...

Principalmente dos italianos, alemães e eslavos.

Quatro indústrias se destacam na região: calçados, vinhos, móveis e turismo.

\section{Figura 2 - Site Descubra o Brasil}


Já no início de 2007, os primeiros certificados de conclusão de curso foram entregues pela presidente da Embratur aos profissionais de Portugal e Espanha que concluíram o curso, durante a realização das respectivas feiras naqueles países - BTL e Fitur. Vejam que, a cada novo programa e a cada nova etapa vencida de construção de um programa de relacionamento com o mercado internacional, nossos estandes em feiras vão ganhando outra agenda, com uma nova qualidade.

Este é um dos mais novos programas da Embratur, que recém está iniciando sua segunda etapa, mas é interessante aqui comentar um e-mail recebido de um agente português que, ao fazer seu trabalho final para avaliação dos tutores, tendo que organizar um roteiro no Brasil a partir do que aprendera, nos informou que acabara de vender aquele roteiro a um casal de clientes.

\subsection{Projeto Excelência em Turismo: Aprendendo com as Melhores Experiências INTERNACIONAIS}

O projeto Excelência em Turismo: Aprendendo com as Melhores Experiências Internacionais foi lançado pela Embratur em 2005 e desenvolvido por meio de uma parceria institucional com o Sebrae Nacional, tendo contado com a Braztoa como parceira executora do projeto. Aplicado pela primeira vez no Brasil, o projeto baseia-se no conceito de benchmarking e consiste na ação de identificar, aprender e adaptar práticas e processos reconhecidos pela qualidade e excelência em setores específicos, seja em organizações privadas ou em destinos.

É importante destacar que desenhamos e implementamos o primeiro projeto de benchmarking para destinos turísticos do Brasil visando acelerar o processo de melhoria da qualidade do produto turístico brasileiro, a tempo de conseguir atender às demandas e exigências dos turistas internacionais que crescentemente visitam o país. Esta necessidade ficou evidente quando, em decorrência do expressivo crescimento da chegada de estrangeiros ao país, marcada também pela diversificação de destinos procurados, verificamos que era necessário rapidamente proporcionar aos profissionais 
envolvidos nos diversos segmentos da cadeia produtiva, uma vivência com os mesmos padrões de atendimento, comercialização e promoção, aos quais estes clientes estavam acostumados no exterior.

Benchmarking é uma palavra que passou a ser bastante conhecida a partir da última década do século XX. Trata-se de uma abordagem gerencial para identificar “quem é melhor?” e “o que os leva a tanto sucesso?'. Essa prática vem ganhando muita popularidade, tanto na indústria quanto nas organizações prestadoras de serviços. $\mathrm{Na}$ teoria da administração, benchmarking é usualmente posicionado como sendo uma extensão de um programa de qualidade total, a partir do qual é possível implementar padrões de maior eficiência e desempenho como um todo. Entende-se essa ação, portanto, como uma maneira de se melhorar as atividades e os negócios, processos e o próprio gerenciamento da empresa.

Para o desenho do Excelência em Turismo levamos em consideração a necessidade de adaptação da metodologia para que fosse possível atender às particularidades dos empresários que respondem pelos segmentos do turismo brasileiro prioritários para promoção internacional, de acordo com o Plano Aquarela.

A essência do benchmarking consiste na idéia de que nenhuma organização ou destino é o melhor em tudo, o que implica reconhecer que existe alguém dentro do mercado que pode fazer melhor. A prática não significa um evento isolado, o qual ocorre uma única vez. Não significa uma investigação que fornece respostas simples e receitas prontas. Não é uma cópia ou imitação. Não é mais um modismo da administração. Trata-se de uma ferramenta viável que fornece informações úteis para melhorar praticamente qualquer atividade de negócios, a partir de um processo de aprendizado com os outros, uma busca pragmática de idéias.

O planejamento do Excelência em Turismo seguiu estes conceitos teóricos e trouxe à prática a possibilidade dos operadores de turismo receptivo do Brasil observarem e compararem práticas similares às suas, em países de reconhecimento internacional por excelência em segmentos turísticos prioritários para promoção internacional, dando início ao processo de melhoria dos produtos que oferecem aos turistas internacionais.

No primeiro ano de execução do projeto, ou seja, em 2005, foram selecionados e 
atendidos 70 operadores com origem e atuação em 20 estados brasileiros, que participaram das seguintes viagens técnicas:

1. Costa Rica - excelência em Ecoturismo, com ênfase para gestão de Parques Nacionais e esportes praticados na natureza, além da observação do processo de comercialização internacional adotado com sucesso;

2. Peru - excelência em Ecoturismo, com ênfase na logística de turistas em áreas de difícil acesso (região Amazônica) e observação de aves;

3. México - excelência em Mergulho, com ênfase na inclusão da prática do esporte na cadeia de comercialização do produto turístico;

4. Espanha - excelência em Turismo Cultural, com ênfase na formatação de rotas e roteiros turísticos, envolvendo patrimônios nacionais e/ou mundiais da Humanidade;

5. Nova Zelândia - excelência em turismo de aventura, certificação e comercialização da atividade;

6. Argentina - excelência em pesca esportiva em águas interiores. Também no foco da promoção internacional desse produto em especial.

O projeto, além de subsidiar parte dos investimentos dos empresários participantes das viagens técnicas, desenvolveu também toda a metodologia de apoio ao operador no processo inicial de aplicação dessa nova ferramenta. Durante as visitas aos países, os empresários são acompanhados por dois consultores técnicos, um nacional e um internacional, que dão suporte à aplicação do processo de benchmarking em sua empresa. A partir de então, existem determinações acordadas entre os participantes e as entidades organizadoras do projeto em relação a direitos e deveres. Por parte dos operadores, cabe realizar no mínimo três iniciativas de multiplicação do aprendizado em suas localidades de atuação. Eles são orientados a liderarem a organização do evento, seja ela uma oficina, uma palestra ou um workshop. Aos gestores do projeto, a responsabilidade está na entrega de materiais técnicos finais, como dois vídeos completos sobre a visita, um relatório técnico completo, bem como uma apresentação em power point padrão que compila os principais pontos observados.

Além disso, os empresários são monitorados por meio das Unidades Estaduais do Sebrae e também por relatório trimestral de avaliação cobrado pela Braztoa. Essas 
informações são compiladas e acompanhadas trimestralmente pelas instituições gestoras do projeto.

Todos os números e relatórios finais seguem os indicadores de resultados previamente estabelecidos, sendo que os resultados apontados e a avaliação final do ano de 2005 foram positivos e mostraram indicativos de que o projeto deveria ser mantido. No entanto, apesar de todo o sucesso obtido e comprovado por meio de reuniões e oficinas de trabalho com os participantes do projeto, as instituições organizadoras avaliaram também a necessidade de aprimorar estratégias, tais como a de buscar melhorar ainda mais a metodologia de benchmarking até então aplicada.

Em 2006, o projeto lançado em março, apresentou os aprimoramentos na linha estratégica. A metodologia de benchmarking de apoio ao empresário durante sua participação no projeto, bem como orientações para dar seguimento à ferramenta na prática diária de sua empresa ganhou aperfeiçoamentos. O objetivo é tornar o projeto cada vez mais eficaz e preciso no apoio ao empresário, quando falando da possibilidade de se aumentar a qualidade do produto turístico que é oferecido no Brasil ao turista internacional.

Em 2006 foram realizadas quatro viagens técnicas tendo sido atendidas 45 empresas:

1. África do Sul - excelência em ecoturismo, gestão e uso de Parques Nacionais;

2. Caribe - San Martin - excelência em Sol e Praia;

3. Estados Unidos - excelência em Negócios e Eventos;

4. Espanha - excelência em Eventos Esportivos e Culturais.

O principal objetivo do projeto é incentivar o operador de turismo receptivo local a melhorar a qualidade dos serviços executados e oferecidos ao turista internacional quando de sua visita ao Brasil.O resultado final será não só produtivo para o empresário participante, mas também para o país como um todo, uma vez que mais de 50 destinos turísticos de todo o território nacional já estão envolvidos no processo de melhoria contínua de suas atividades e negócios internacionais. 


\subsection{ESCRITÓRIOS BRASILEIROS DE TURISMOS (EBTS)}

O marco referencial da implantação de escritórios de turismo no exterior remonta ao inicio da década de 1920 por parte da França, e de 1929 pela Espanha. Não por coincidência, sempre foram destes mesmos países as primeiras posições no ranking da OMT como principais destinos turísticos do mundo.

A iniciativa brasileira de implantação de seus escritórios começou em meados dos anos 1980, em países como Alemanha (Frankfurt), Itália (Milão), Espanha (Madri) e Estados Unidos (Nova York). Com um trabalho desenvolvido por consultores contratados pela Embratur, em uma situação muito semelhante à atual, os escritórios funcionaram por alguns anos. Os relatórios mostram que os resultados ficaram aquém dos esperados no acréscimo de entrada de turistas estrangeiros no Brasil. Para citar apenas alguns dos motivos que relatam o desempenho mediano citado naquela primeira tentativa, poderíamos destacar: a falta de continuidade dos programas e a não existência de uma seqüência lógica de programas de promoção internacional; o direcionamento equivocado das ações, pois o foco central era o de efetuar ações institucionais, fato ligado a concepção vigente quanto ao papel da Embratur naquele período.

Infelizmente não há documentos disponíveis nos arquivos da Embratur além destes relatórios, mas pode-se inferir, pelas informações disponíveis nos balanços de encerramento de exercício anual daquele período, que o programa foi abortado por não fazer parte de uma estratégia de atuação no mercado internacional que contasse com outros programas de apoio. Isolados e sem recursos para integrar-se em uma política de promoção do Brasil no exterior, esta primeira experiência não deixou literatura ou história gerencial.

O quadro abaixo demonstra a estrutura de alguns concorrentes no contexto do mercado turístico internacional e suas estruturas de funcionamento: 
Estrutura de Funcionamento de Concorrentes Turísticos Internacionais

\begin{tabular}{|c|c|c|c|}
\hline & $\begin{array}{c}\text { Escritórios } \\
\text { no Mundo (2005) }\end{array}$ & $\begin{array}{c}\text { Funcionários } \\
\text { no Exterior (2005) }\end{array}$ & Início das Operações \\
\hline FRANÇA & 33 & 280 & década de 1920, em Barcelona \\
\hline ESPANHA & 31 & 208 & 1929, em Londres e Paris \\
\hline MÉXICO & 17 & 50 & 1952, em Nova York \\
\hline ARGENTINA & 04 & 08 & 1991 em Miami \\
\hline ÁFRICA DO SUL & 09 & 41 & década de 1950, em Londres \\
\hline CHINA & 16 & 30 & - \\
\hline
\end{tabular}

Quadro 6 - Estrutura de Funcionamento de Concorrentes Turísticos Internacionais

Pelos dados apresentados, podemos observar que o Brasil encontra-se com uma considerável necessidade de melhoria nesse quesito, pois grandes concorrentes apresentam estruturas de promoção comercial há mais de 80 anos, o que facilita sua atuação e a consolidação de suas ações nos mercados alvo.

Segundo os dados da OMT, em 2003, a França, precursora na modalidade de escritório de turismo no exterior, recebeu 75 milhões de turistas estrangeiros. Já a Espanha contou com 52,5 milhões e o México, com 16 escritórios, atingiu a marca de 18,7 milhões de turistas internacionais. Registre-se sempre, para não gerarmos leituras apressadas e equivocadas, que, majoritariamente, estes países recebem visitantes de seus vizinhos, pois seus passageiros, segundo pesquisas, voam, até duas horas e meia para chegar a seus destinos.

No caso do Brasil, a estratégia de implantação dos EBTs levou em consideração as definições apontadas tanto pelo Plano Nacional de Turismo, quanto pelo Plano Aquarela. Nesse último, vale relembrar, foram identificados 16 mercados prioritários, países esses que são os maiores emissores de turistas ao Brasil ou países com grande potencial de emissão. Por meio dos EBTs e dos Comitês Descubra Brasil (implantados em toda a América do Sul), os vinte maiores países emissores de turistas ao Brasil estão cobertos e contemplados pelas atividades estabelecidas na agenda de promoção comercial do turismo brasileiro.

No caso da implantação dos EBTs, a estratégia foi executada por etapas, havendo o desenvolvimento em dois estágios. O primeiro foi efetuado por meio de parceria com a FBC\&VB, na qual a estratégia central era realizar uma primeira aproximação junto ao mercado local, iniciando o uso de ferramentas de relacionamento. 
O foco era centrado na atuação do executivo responsável pelo Escritório e na forma como ele se relacionaria com o mercado de forma geral. No segundo momento, após dois anos de trabalho, ao perceber as oportunidades desse sistema e a necessidade de inovações, decidimos passar para um segundo modelo. Realizamos um processo licitatório, com o objetivo de contratar uma empresa especializada em marketing promocional, que se aproveitaria de sua expertise na área de marketing para efetivar transferência de cultura gerencial e de ferramentas de gestão inovadores ao programa em questão. Uma vez finalizada a licitação e contratada a empresa, estabelecemos uma nova estratégia de mercado. A mudança de modelo foi possível por meio de um estudo detalhado a respeito das ações e do tempo que era necessário para a realização de cada uma das atividades, bem como uma análise pormenorizada da relação custo-benefício do conjunto de projetos postos em prática, com o executivo passando a ser um profissional voltado exclusivamente para atendimento e relacionamento com o mercado turístico, consolidando contato com operadores, companhias aéreas e agências de viagem. Para assumir a lacuna até então coberta pelos executivos no modelo anterior, a Embratur fez mais uma licitação, e contratamos duas agências de relações públicas que se responsabilizam pela abordagem, relacionamento e contatos com a imprensa e formadores de opinião.

A agenda do EBT compreende portanto:

- Contato com Operadores de Turismo;

- Contato com Agentes de Viagem;

- Contato com Profissionais e Meios de Comunicação;

- Contato com Decision Makers na área de Incentivos;

- Contato com Decision Makers em relação a Eventos Asociativos;

- Contato com Decision Makers em relação a Eventos Corporativos;

- Participação em Eventos de Promoção constantes da agenda da Embratur;

- Participação em Eventos de Promoção gerados por outros players, brasileiros ou estrangeiros;

- Elaboração e envio ao Brasil de um conjunto de informações e análises.

Outro componente implantado na segunda fase foi a constituição de uma equipe de apoio com base em Brasília, a qual sistematiza as informações necessárias para as 
tomadas de decisões, bem como gerencia atividades básicas para o bom funcionamento do modelo, como ferramenta informatizadas e atualizadas on line organizando todas as informações necessárias para nosso conhecimento qualificado dos atores com quem nos relacionamos no exterior. Essa ferramenta também organiza a agenda de todos os executivos no exterior, de modo a permitir que suas atividades sejam monitoradas e acompanhadas diariamente pelos gestores do processo.

Toda a atividade é gerenciada com base nos indicadores de resultados estabelecidos, visando atingir as metas definidas no PNT. Dessa forma, os EBTs complementam e integram-se com todo o trabalho da equipe Embratur, acompanhados com relatórios periódicos de mercado, articulando-se com:

1. as agendas promocionais;

2. o programa de treinamento de operadores e agente de viagens;

3. o apoio a eventos estratégicos do mercado;

4. os seminários Descubra o Brasil;

5. a definição do público e locais a serem visitados pelo programa Caravana Brasil os Press Trips;

6. a participação em feiras de turismo e feiras comerciais; e finalmente com

7. a captação e a promoção de eventos internacionais.

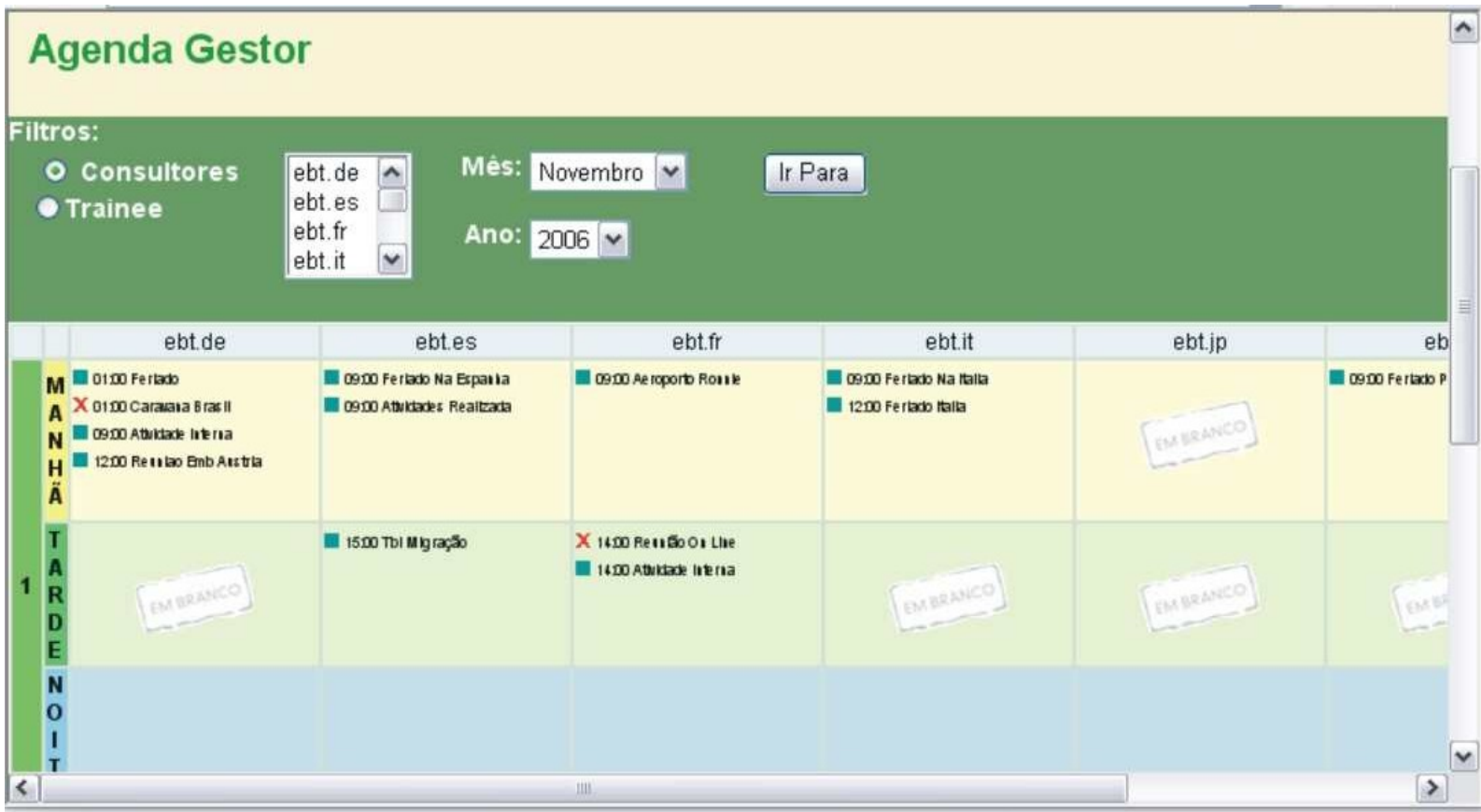




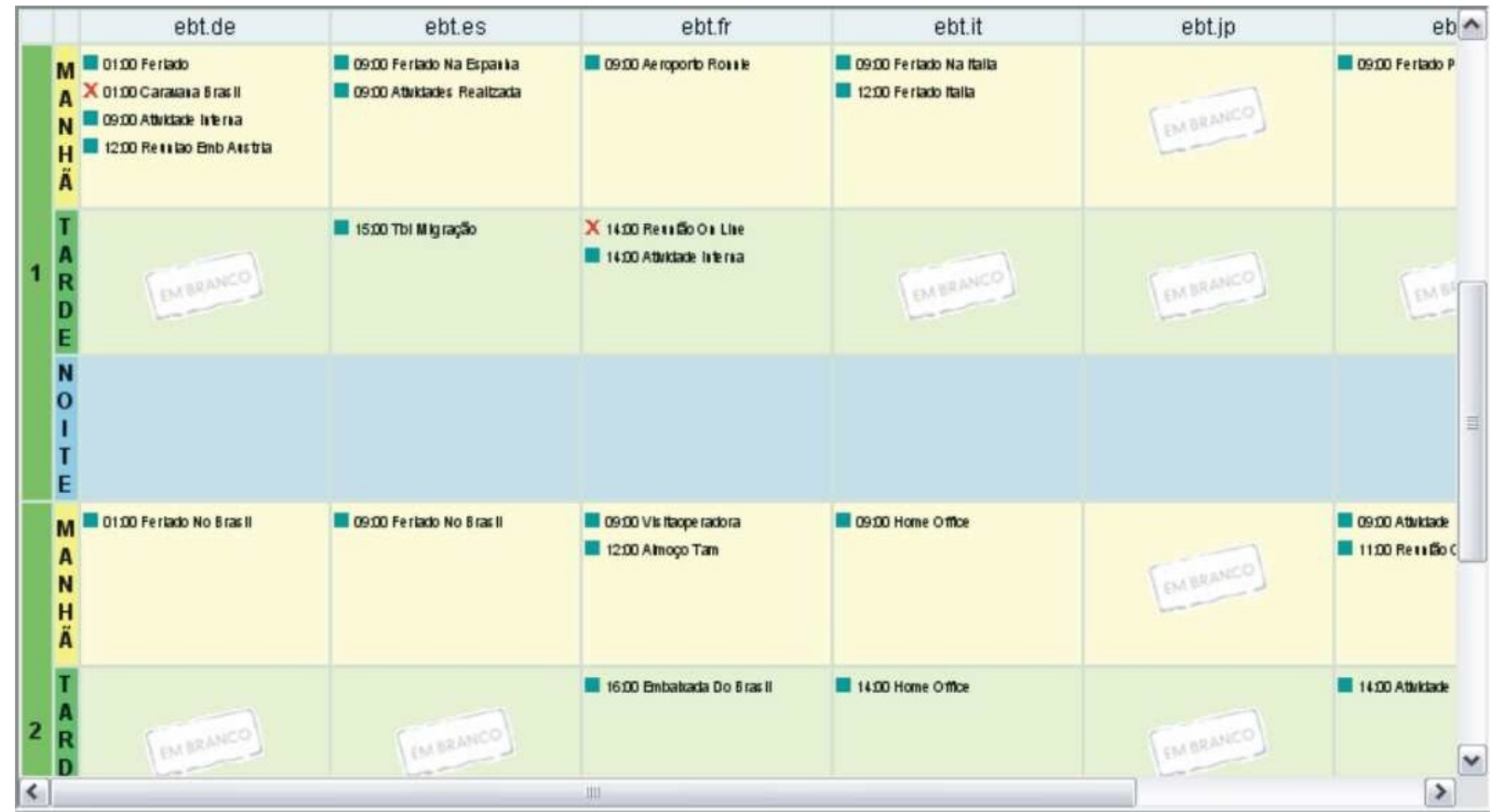

Figura 3 - Agenda Gestor - Novembro

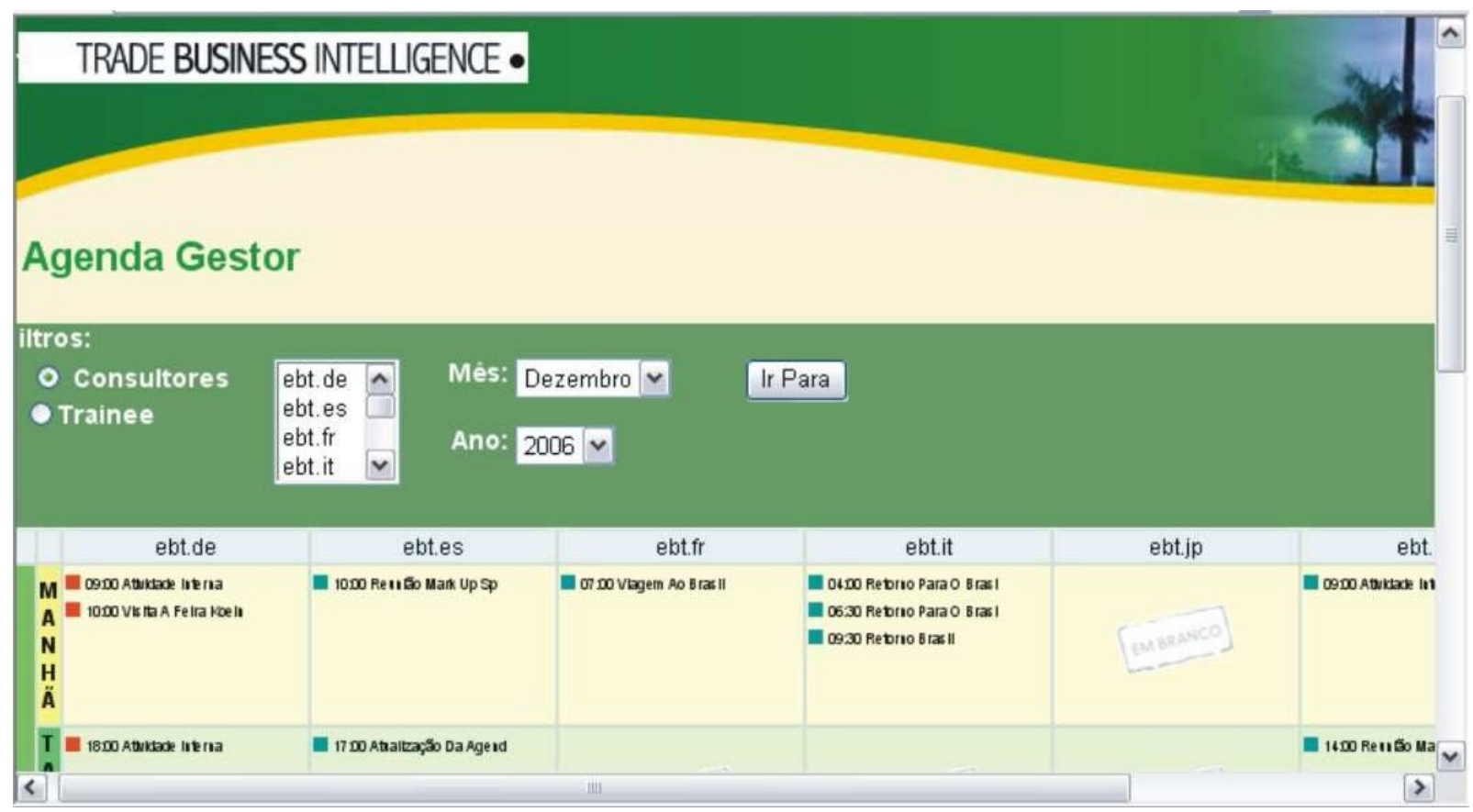

Figura 4 - Agenda Gestor - Dezembro

Atualmente, os EBTs em funcionamento são:

- Portugal - com base em Lisboa;

- Espanha - com base em Madrid; 
- França - com base em Paris;

- Itália - com base em Milão;

- Inglaterra - com base em Londres;

- Alemanha - com base em Frankfurt;

- Estados Unidos da América - com base em Nova York;

- Japão - com base em Tókio;

- América Latina - com base em Brasília.

Notem que a base do EBT não é necessariamente a capital política do país em que está situado, mas necessariamente tem que ser a capital econômica. Por isso a decisão por Milão e Frankfurt, em detrimento de Berlim e Roma.

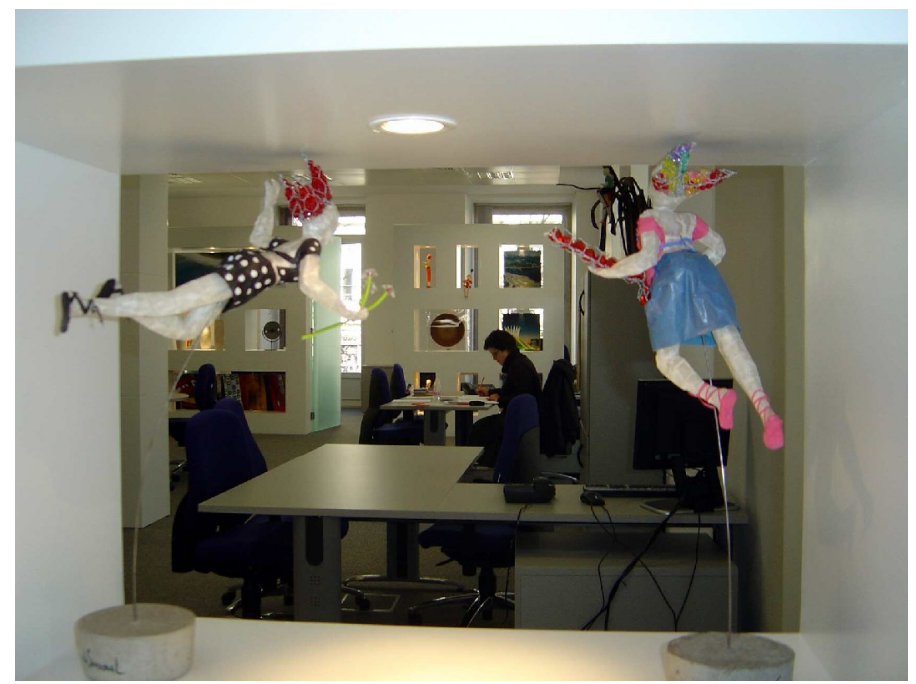

Foto 5 - EBT Lisboa

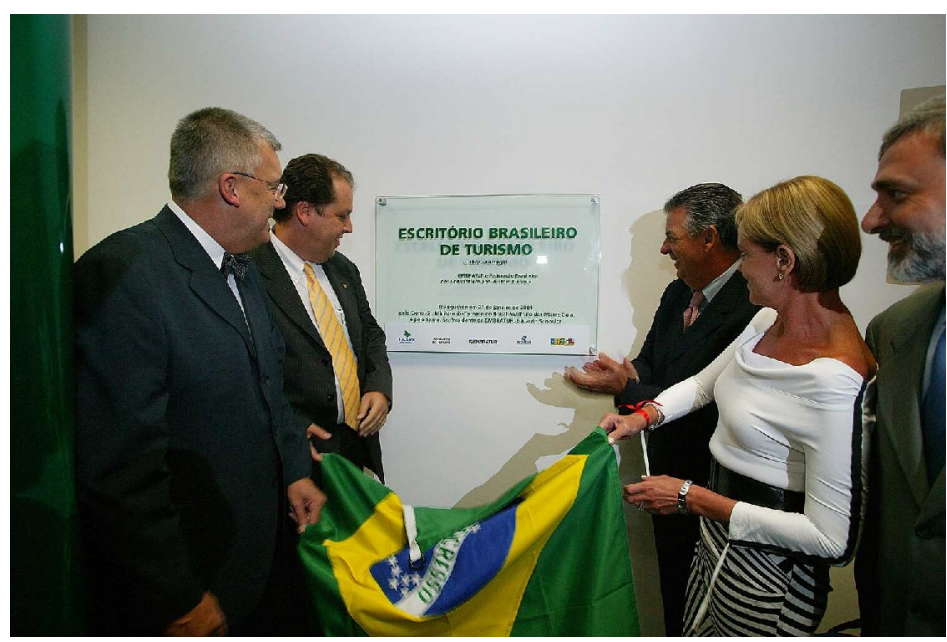

Foto 6 - EBT Lisboa 
Outro tema a destacar é o EBT da América Latina: nós decidimos lançar o programa com ele, por acreditarmos que tínhamos que começar com nossos vizinhos, para demonstrar a importância que damos a nossa região, e mais ainda, porque sabíamos que o conjunto de programas que estávamos implantando iria um dia, finalmente, desmentir o velho discurso dos anos 1990, de que o Brasil estava condenado a ser um eterno destino apenas para latino-americanos. Nós tínhamos absoluta confiança de que, com o tempo e o desenvolvimento de nossas iniciativas, iríamos obter a superação dos latino-americanos pelos europeus em termos de número de visitantes, e como conseqüência assistiríamos a um crescimento importante do ingresso de divisas. Foi com emoção, portanto, mas sem surpresas, que nossa equipe recebeu a famosa manchete do jornal O Globo sobre o tema, ao início de 2005.

Gostaria de registrar ainda, que o lançamento do EBT para América Latina em 11 de setembro não estava relacionado ao atentado terrorista em Nova York, mas, sim, era uma homenagem nossa a Salvador Allende, assassinado nesta data, em 1973, pelo fascismo chileno. Era nossa maneira de dizer, para os que quisessem compreender, que tínhamos consciência de nosso lado neste processo, e mais, que tínhamos consciência do que pretendíamos, ao relançar a imagem do Brasil ao redor de nosso continente. A decisão seguinte, de lançar os Comitês Descubra Brasil por todo o continente (após analisarmos porque não vingaram os antigos Comitê Visit Brasil ao redor do mundo, cujo único sobrevivente foi o da Argentina) se deu na mesma linha: em se tratando de América Latina, era fundamental criar uma estrutura orgânica de atuação, sob nossa coordenação, com sustentação em bases locais, a cada país, a fim de mostrar claramente nosso compromisso com a região.

Tendo sido o mais polêmico e discutido programa implantado neste período, os EBTs foram ganhando apoio e sustentação do mercado, na medida em que, como prevíamos, seus resultados foram se tornando visíveis para o mercado, para a sociedade e para o governo. O ganho de escala nas ações da Embratur, e os resultados apresentados ao país, como demonstramos abaixo, acabaram por ser reconhecidos e premiados, como dito antes, no $11^{\circ}$ Concurso Inovação na Gestão Pública Federal, promovido pela Enap. Foi a primeira vez que a Embratur ganhou este prêmio. 


\subsection{Caravana Brasil}

O projeto Caravana Brasil surgiu no desafio de identificar quais produtos brasileiros tinham potencial de promoção no exterior e quem eram os responsáveis pela sua promoção. Em uma primeira análise, baseada em pesquisas pela Internet com entidades do setor, feiras de turismo e brochuras de operadores brasileiros e estrangeiros, ficou claro que o Brasil estava sendo comercializado com poucos produtos e por poucas empresas. Isso data ainda de 2003, quando não havia sido realizado o Plano Aquarela - Marketing Turístico Internacional.

A missão passou a ser construir uma ferramenta de promoção que tivesse continuidade, atendesse aos operadores brasileiros e internacionais e mostrasse 0 Brasil inteiro, com toda a sua diversidade.

Para essa tarefa surgiu oportunamente o apoio de uma associação que estava formada há certo tempo e tinha necessidade de se promover com mais força no exterior: a Associação Brasileira de Resorts (ABR), posteriormente conhecida como Resorts Brasil. Elaboramos em conjunto um plano de trabalho para a operação do projeto Caravana Brasil, que surgiu com os seguintes objetivos:

- Aumentar o número de operadores que vendiam Brasil;

- Aumentar o número de destinos oferecidos no exterior;

- Ser uma ferramenta de apoio à comercialização.

Como era claro que o setor de receptivo brasileiro estava distante de novos produtos, o projeto, em 2003 e até meados de 2004, concentrou suas saídas para os operadores brasileiros do receptivo internacional.

As viagens obedeciam a um calendário previamente definido pela Embratur, por meio da Diretoria de Turismo de Lazer e Incentivo. Os grupos eram formados por um número de 10 a 15 operadores brasileiros, um ou dois veículos de imprensa (especializada ou não no segmento), um técnico da Embratur, um técnico do Mtur, um representante da Infraero e um jornalista da Assessoria de Comunicação (Ascom) da 
Embratur.

Para viabilizar o projeto dentro das condições orçamentárias que se apresentavam, e pela relevância do mesmo junto ao trade, a Varig concedeu condições excepcionais de operação e, até meados de 2004, foi a transportadora oficial do projeto. Devido ao crescimento do número de saídas, a partir desse momento a TAM e a TAP passaram a transportar os participantes também.

As viagens tinham também apoio logístico e operacional das secretarias ou órgãos de turismo estadual.

Em todas as saídas eram previstas rodadas de negócios, onde era possível aproximar o trade local do destino visitado dos operadores participantes do projeto. As rodadas aconteciam em cerca de três a quatro horas e traziam a possibilidade de negócios entre os participantes.

Como forma de avaliação das saídas, em toda viagem era aplicado um questionário com perguntas relativas ao destino, ao projeto e a rodada de negócios. Baseadas na tabulação de dados desses questionários foram sendo tomadas medidas de ajuste do projeto em sua concepção e operação.

No segundo semestre de 2004, aconteceu a primeira saída do projeto com operadores internacionais. Era hora de expandir os horizontes e começar a trazer quem realmente importava para a comercialização do Brasil no exterior.

O objetivo de aumentar o conhecimento do produto brasileiro entre os operadores de receptivo nacional vinha sendo atingido. Dados da Braztoa informam que, de 2003 a 2004, o número de associados ligados ao receptivo internacional cresceu de 6 para 19 empresas, comprovando que a meta de aumentar o número de operadores vinha sendo cumprida. Era hora também de rever os critérios de operação das viagens.

Em função disso, na renovação do convênio que possibilitava a operação e logística do projeto, foi feita uma inovação e a Bito tornou-se parceira oficial para o projeto Caravana Brasil, a partir de junho de 2005.

O fato de ter agora como parceiro uma das entidades mais representativas do setor deu maior agilidade e qualidade operacional ao projeto. Em 2005, os números que seguem abaixo comprovaram sua consolidação e sucesso. 
O foco de atuação se fortaleceu nos operadores internacionais. Foram criados critérios mais justos de seleção dos participantes junto aos EBTs, com base também nas informações do Plano Aquarela, que passou a reger a definição de mercados, destinos e atrativos no Brasil.

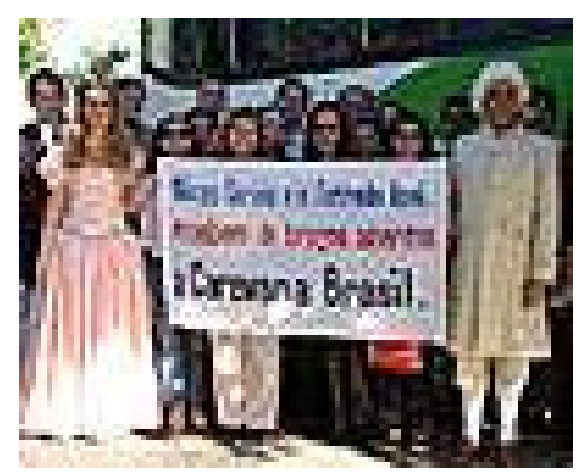

Foto 7 - Caravana Brasil Estrada Real

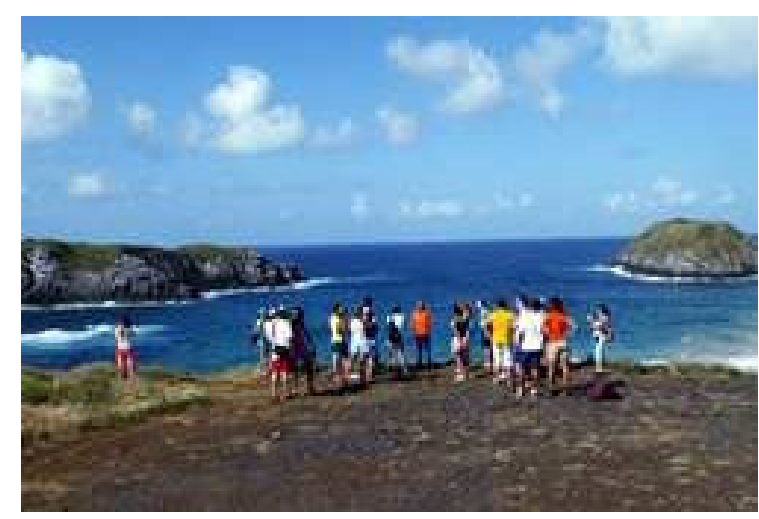

Foto 8 - Caravana Brasil Fernando de Noronha

Os resultados do projeto, como dito, são satisfatórios. Vejam o quadro com a evolução de 2003 a 2006:

\begin{tabular}{|c|c|c|c|c|c|c|c|}
\hline \multicolumn{3}{|c|}{ Resultados Projeto Caravana Brasil } & 2003 & 2004 & 2005 & 2006 & TOTAL \\
\hline \multicolumn{3}{|c|}{ agentes econômicos envolvidos } & 70 & 485 & 866 & 974 & 2395 \\
\hline \multicolumn{3}{|l|}{ destinos visitados } & 16 & 86 & 165 & 174 & 441 \\
\hline \multicolumn{3}{|c|}{ jornalistas especializados } & 17 & 53 & 13 & 10 & 93 \\
\hline \multicolumn{3}{|l|}{ operadores brasileiros } & 89 & 142 & 43 & 39 & 313 \\
\hline \multicolumn{3}{|l|}{ operadores estrangeiros } & 0 & 48 & 244 & 279 & 571 \\
\hline Viagens Realizadas & 2003 & 2004 & 2005 & 2006 & \multicolumn{2}{|c|}{ TOTAL } & \\
\hline Nacionais & 6 & 11 & 4 & 5 & \multicolumn{2}{|c|}{26} & \\
\hline Internacionais & 0 & 8 & 28 & 38 & \multicolumn{2}{|c|}{74} & \\
\hline TOTAL & 6 & 19 & 32 & 43 & \multicolumn{2}{|c|}{100} & \\
\hline
\end{tabular}

Quadro 7 - Resultados do Projeto Caravana Brasil 
A qualidade do projeto ainda pode ser analisada pelas informações consolidadas das pesquisas de opinião e pelo depoimento de alguns participantes do projeto, como segue.

A seguir, um resumo geral das informações obtidas com a realização da pesquisa de opinião, com o resultado final da compilação dos questionários aplicados a 200 operadores de turismo convidados pela Embratur a participar do projeto Caravana Brasil, realizadas até o dia 12 de novembro 2005, visitando diversos estados brasileiros.

Tabela 1 - Pesquisa de Opinião: Atualização Mercadológica

\begin{tabular}{|l|c|c|}
\hline $\begin{array}{l}\text { Na sua opinião, os novos roteiros apresentados são considerados } \\
\text { importantes? }\end{array}$ & \\
\hline Sim & 58 & $76,3 \%$ \\
\hline Sim, parcialmente & 11 & $14,5 \%$ \\
\hline Não & 7 & $9,2 \%$ \\
\hline Total & 76 & $100 \%$ \\
\hline
\end{tabular}

Fonte: Embratur/Mtur 2005

Nesta questão, buscamos identificar a importância mercadológica dos destinos turísticos brasileiros visitados pelo Projeto Caravana Brasil em 2005. Do total de respostas obtidas nesta questão, $76,3 \%$ dos entrevistados responderam que os roteiros apresentados foram considerados importantes para a diversificação de seus produtos, outros $14,5 \%$ afirmaram que esta afirmação é parcialmente verdadeira e apenas 9,2\% dos entrevistados acreditam que os novos roteiros apresentados não são importantes para a diversificação da oferta dos atrativos nacionais.

Tabela 2 - Pesquisa de Opinião: Avaliação dos Destinos Visitados - Comercialização

\begin{tabular}{|l|c|c|}
\hline $\begin{array}{l}\text { Avalie a preparação do destino para a comercialização no mercado } \\
\text { internacional. }\end{array}$ & \\
\hline Não responderam & 39 & $6,8 \%$ \\
\hline Está pronto para ser comercializado & 389 & $68,0 \%$ \\
\hline Necessita de aprimoramentos & 128 & $22,4 \%$ \\
\hline Não atende às exigências do mercado internacional & 16 & $2,8 \%$ \\
\hline Total & 572 & $100 \%$ \\
\hline
\end{tabular}

Fonte: Embratur/Mtur 2005 
Do total de respostas obtidas dentre os vários destinos visitados, $68,0 \%$ dos entrevistados indicaram que estes roteiros brasileiros se encontram prontos para serem comercializados. Para $22,4 \%$ dos operadores presentes nas Caravanas, os destinos necessitam de algumas melhorias, outros 6,8\% não se propuseram a responder esta questão e apenas $2,8 \%$ dos entrevistados afirmam que alguns destinos ainda não atendem às exigências do mercado internacional.

Tabela 3 - Pesquisa de Opinião: Sugestões de Melhorias para a Comercialização do Turismo Brasileiro

\begin{tabular}{|l|c|c|}
\hline $\begin{array}{l}\text { Quais seriam as suas sugestões para melhorar a comercialização dos } \\
\text { destinos visitados? }\end{array}$ & \\
\hline Promoção & 53 & $25,1 \%$ \\
\hline Capacitação da Mão de Obra & 35 & $16,6 \%$ \\
\hline Transporte & 27 & $12,8 \%$ \\
\hline Atrativos & 26 & $12,3 \%$ \\
\hline Infra-estrutura Turística & 25 & $11,8 \%$ \\
\hline Hospedagem & 20 & $9,5 \%$ \\
\hline Fluência em idiomas & 15 & $7,1 \%$ \\
\hline Conscientização da População e Turistas & 10 & $4,7 \%$ \\
\hline TOTAL & 211 & $100 \%$ \\
\hline
\end{tabular}

Fonte: Embratur/Mtur 2005

A impressão geral sobre as Caravanas foi positiva. A maioria dos entrevistados afirmou que a viagem foi deslumbrante e que conheceram regiões belíssimas, porém foram citadas diversas melhorias para a melhor comercialização dos destinos turísticos brasileiros.

Entre as objeções citadas pelos entrevistados listam-se:

\section{Maior Promoção e Marketing do Brasil no exterior}

Com 25,1\% das citações, os entrevistados sugeriram:

- Maior divulgação de novos atrativos brasileiros no mercado internacional, através de DVDs, folheteria e programas de TV;

- O Brasil precisa de mais cobertura na mídia internacional com foco nos diversos segmentos, de forma clara e verdadeira para atrair novos turistas;

- Necessidade de oferecer mais visitas in loco para os agentes de viagens e operadores conhecerem os destinos comercializados e melhorar sua promoção; 
- Utilizar mais a Internet como fonte de informações;

- Mais participação em eventos;

- Necessidade de especialização em determinados nichos de mercados e direcionamento do público alvo.

Capacitação da mão de obra turística

Para $16,1 \%$ dos entrevistados o turismo brasileiro necessita de uma profissionalização dos profissionais de turismo, as principais críticas e sugestões foram:

- Os operadores locais deveriam conhecer alguns destinos internacionais, realizando um benchmarking para ter uma referência do modo como os receptivos internacionais trabalham, e assim melhorar os serviços;

- Os guias precisam ser qualificados para trabalhar, tendo um maior conhecimento histórico do local, mais objetividade e fluência em outros idiomas;

- Oferecer treinamento para a mão-de-obra do trade turístico, principalmente guias e funcionários dos meios de hospedagem;

- Disponibilizar de profissionais especializados nos diversos segmentos.

\section{Melhoria no transporte turístico}

Segundo $12,8 \%$ dos entrevistados é preciso investir na qualidade do transporte brasileiro. Dentre as carências sugere-se:

- A principal queixa dos entrevistados é em relação ao transporte aéreo, onde se sugere melhorar as conexões aéreas, oferecendo mais vôos e em horários diferenciados;

- Os turistas internacionais não se interessam em viajar tanto tempo de ônibus;

- Os meios de transporte, principalmente o terrestre, devem estar em bom estado de conservação e limpos. Onde o acesso for difícil, oferecer transportes com conforto para não cansar os turistas, como ar condicionado, bons acentos, cabines protegidas contra chuva e poeira etc.;

- Melhorar as vias de acesso para um trânsito melhor e mais seguro de veículos e pedestres.

Melhoria dos Atrativos 
Com $12,3 \%$ das citações, os entrevistados sugeriram as seguintes melhorias dos atrativos visitados:

- Estruturar melhor os roteiros turísticos, organizando a duração dos passeios e oferecendo city tour focado aos diferentes tipos de turistas e suas faixas etárias;

- Melhorar a infra-estrutura dos atrativos, investindo mais nas regiões turísticas;

- Aumentar a oferta de atrativos e opções de lazer, principalmente noturno.

Mais investimentos na infra-estrutura turística

Para $11,8 \%$ dos entrevistados é preciso investir mais na infra-estrutura dos destinos visitados. Dentre os principais pontos encontram-se:

- Melhoramento contínuo das infra-estruturas turísticas do país;

- Implantação de novos empreendimentos, oferecendo mais e melhores opções de alimentação e lazer;

- Melhorar a imagem dos atrativos, restaurando a arquitetura turística da cidade, reurbanização das orlas, limpeza das ruas e praias e maiores cuidados com as áreas de preservação ambiental para atender melhor o mercado internacional.

\section{$\underline{\text { Investimentos nos meios de hospedagem }}$}

Segundo $9,5 \%$ dos entrevistados é preciso investir na qualidade dos meios de hospedagem. Dentre as carências sugere-se:

- Adequar ao padrão internacional, com qualidade nos serviços e mão-de-obra treinada; - Necessidade de uma melhor infra-estrutura hoteleira, melhorando as condições das unidades habitacionais.

\section{Carência de fluência em outros idiomas}

Para que haja uma boa comunicação entre o trade turístico e os turistas é preciso utilizar profissionais com capazes de se comunicar em outros idiomas, este é um item a ser melhorado no Brasil de acordo com 7,1 Para 16,1\% dos entrevistados, sendo disponibilizadas as seguintes características:

- Os atrativos turísticos necessitam de explicações, tanto escrita como falada, em diferentes idiomas; 
- Os profissionais de turismo também devem ser bilíngües.

\section{Orientação e Conscientização da População e Turistas}

Por fim, para $4,7 \%$ dos entrevistados é preciso que haja uma conscientização da população autóctone e dos turistas para que o turismo se desenvolva no país.

- É preciso orientar melhor os turistas antes da sua vinda ao Brasil para que não tenham problemas de adaptações e saibam o que esperar durante sua viagem. Dentre as principais informações, sugere-se oferecer dados sobre os atrativos turísticos, a real situação do país alertando sobre os locais críticos e mais dicas sobre os itens indispensáveis de bagagem;

- Conscientização da população local sobre a necessidade de preservação dos parques, sobre a importância do turismo para a economia nacional, como recepcionar melhor turistas estrangeiros e incentivo ao artesanato e cultura local.

Pode-se concluir, com isso, que as ações promocionais devem ser planejadas sempre em conjunto. $O$ projeto não teria atingido o êxito que tem sem a participação ativa da iniciativa privada, sem o conhecimento agregado pelas pesquisas do Plano Aquarela e o trabalho apurado dos executivos dos EBTs.

\subsection{Programa de Visitas Técnicas}

Para multiplicar as informações e experiências adquiridas nos programas desenvolvidos a partir de 2003, assim como as obtidas por nós com o Plano Aquarela, a Embratur montou o Programa de Visitas Técnicas, tendo por objetivo apresentar suas estratégias e ações aos profissionais do turismo brasileiro interessados em se aprofundar no tema. A iniciativa busca também demonstrar ao país, de forma transparente, como estão sendo investidos os recursos federais designados à promoção internacional. Nesse sentido, a ocasião da Visita Técnica também considera como resultado a aproximação da equipe da Embratur dos profissionais da área, 
priorizando as instituições públicas de turismo estaduais e municipais, CVBs e escritórios do Sebrae.

A primeira oportunidade surgiu por meio da visita de profissionais da SP Turis, que passaram dois dias conhecendo a estrutura do Instituto, em julho de 2005. A partir de então, foi gerada uma demanda espontânea junto aos profissionais da área. Foi então que a Embratur estruturou este programa.

Além deste objetivo, mais amplo e conceitual, também nos movia, a avaliação de que:

- estávamos cercados por uma mídia geral em tom crescente de oposição ao governo federal;

- limitados à mídia especializada, cuja abrangência é restrita, não formando portanto opinião na sociedade; e

- não observávamos repercussão adequada aos resultados que vínhamos obtendo.

Era necessário portanto iniciarmos projetos alternativos de criação de uma rede de solidariedade e defesa dos programas que vínhamos implantando, que pudesse perpassar as estruturas institucionais estabelecidas. Daí nasceu o roteiro de visitas técnicas: foi antes de tudo uma necessidade de criar um sistema de proteção e blindagem em cada canto do país.

Para melhor atender a todos os convidados e interessados, foi necessário definir uma metodologia de trabalho no ano de 2006. Previmos então, que houvesse duas datas distintas para a realização do programa, considerando convidados das Regiões Sul, Sudeste e Centro-Oeste na visita do primeiro semestre e convidados das Regiões Norte e Nordeste no segundo semestre.

A recepção da primeira visita contou com a presença de 45 profissionais. Desse total de participantes, os resultados obtidos por meio dos questionários de avaliação mostraram que $100 \%$ dos presentes consideraram a visita como esclarecedora sobre os atuais programas de trabalho, bem como uma excelente oportunidade para integração entre as instituições. No segundo semestre, a visita ocorreu nos dias 08 e 09 de agosto, reunindo 38 profissionais das regiões Norte, Nordeste e também CentroOeste, desde técnicos até os próprios secretários de turismo de algumas cidades. Mais uma vez, todos, sem exceção, aprovaram o programa e reconheceram uma 
contribuição importante para o trabalho que desenvolvem nos seus estados.

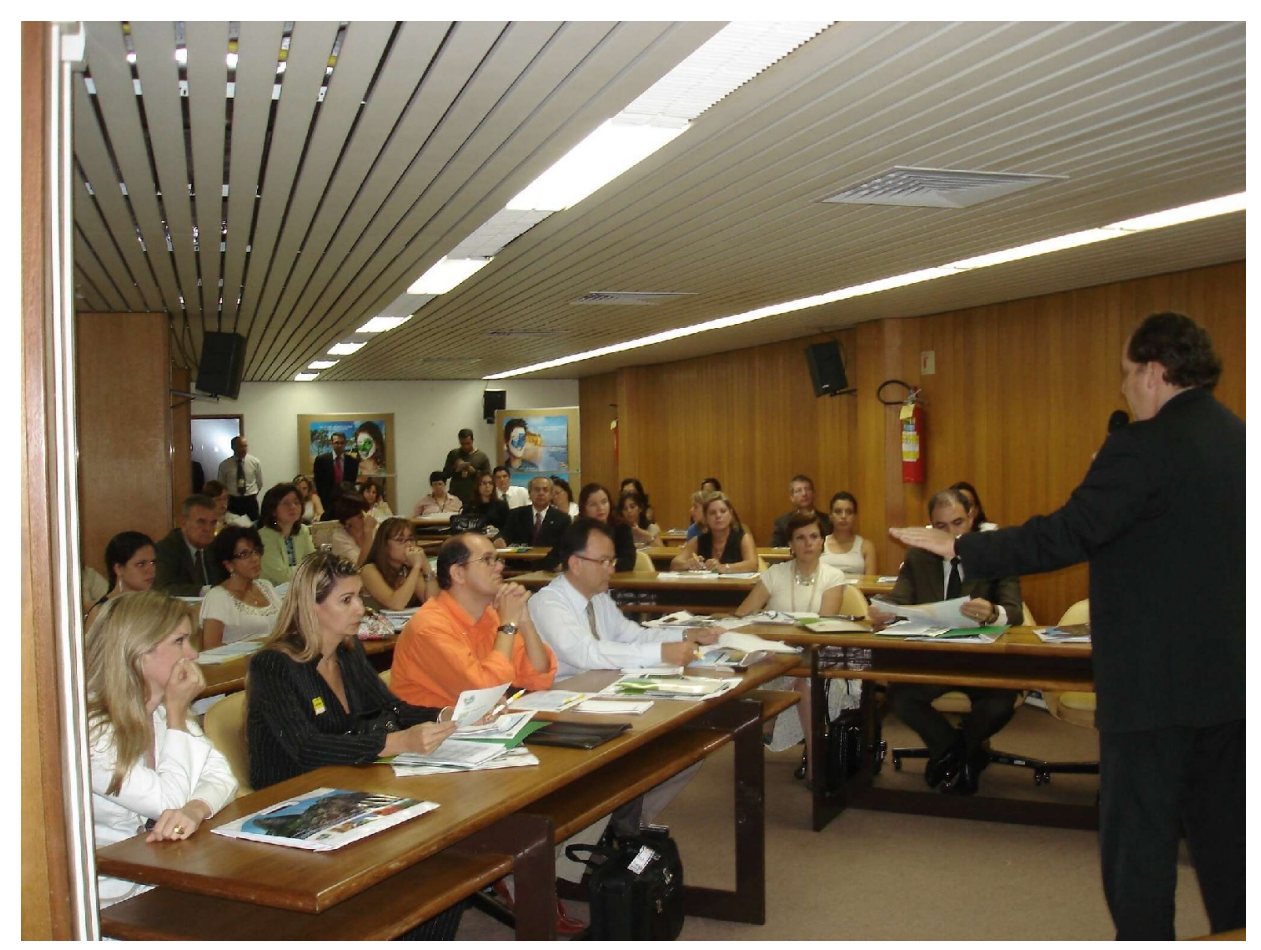

Foto 9 - Reunião do Programa de Visitas Técnicas, em Brasília

A ação propiciou, segundo todas as avaliações, não só uma abertura para o relacionamento junto aos profissionais de turismo de todo o Brasil como uma imagem de transparência em relação às decisões estratégicas que tomamos. $E$ quanto à questão que mais nos afligia durante os dois primeiros anos, conforme mencionei acima - como fazer para ampliar a base de sustentação de nossos programas, para fazer crescer o volume de profissionais que compreendiam e defendiam o conjunto de mudanças que havíamos implantado?

A chance se apresentou quando passamos a notar que em muitos estados, municípios e entidades havia um amplo grupo de pessoas que tratavam de assuntos relacionados a Embratur e aos programas de promoção sustentados com recursos federais, mas que nunca haviam tido contato direto com nossas equipes e, mais, careciam de treinamento e capacitação para avançar no mesmo ritmo em que estávamos avançando. O programa de visita técnicas, portanto, foi criando na medida em que fomos atendendo demandas de todo o país, uma rede de cumplicidade e apoio 
fundamental para a segunda parte do projeto que iniciamos em 2003: o momento em que passarmos a propagar pelo país a necessidade de substituir a Embratur por outro modelo de gestão em promoção internacional. Outro resultado importante foi a possibilidade de identificarmos, por meio de cada um os nossos executivos envolvidos, quem eram, naquele momento, as pessoas-chave em cada organismo com o qual nos relacionávamos para garantir seqüência e qualidade em nossos programas.

Esta rede de relacionamento, informada periodicamente dos atos e resultados da Embratur, por meio dos programas de comunicação (como o Caros Amigos, que em breve será descrito), faria a diferença em muitos momentos de nossa história. Destaco quando, no único episódio em que a oposição política ao Governo Lula tentou envolver o turismo na disputa eleitoral, criando falsas polêmicas a respeito dos EBTs, a rede de relacionamento da Embratur rapidamente posicionou o mercado, este se articulou em defesa de um programa que mostrava resultados concretos e a articulação contrária (que aliás foi rechaçada pelos órgãos de controle federais) esvaziou-se. 


\section{COMUNICAÇÃO E MARKETING}

\subsection{Plano Aquarela - Marketing Turístico Internacional do Brasil}

O Plano Aquarela - Marketing Turístico Internacional do Brasil - surgiu da necessidade de dotar a Embratur de planejamento de curto, médio e longo prazos em sua ações ao redor do mundo, levando em conta que, a partir da reestruturação gerada em 2003, promoção e marketing passam a ser o coração e a razão de ser da Embratur. As ações desenvolvidas, no entanto, neste primeiro momento, basicamente sustentadas conceitualmente pela experiência profissional de nossa equipe, em breve encontrariam seus limites.

A partir do final de 2004, já estava claro para todos nós que, por mais que os programas e resultados gerados por estas experiências profissionais fossem expressivos se comparados com os resultados que a Embratur possuía ao longo dos anos anteriores, isto não seria suficiente para avançar rumo a outro patamar na disputa de mercado internacional. Estava claro que, se queríamos realmente ser ativos nesta disputa, que já se avizinhava - pois em 2004 tínhamos crescido, em passageiros e ingresso de divisas internacionais, pela primeira vez na história da Embratur, acima da média mundial divulgada pela OMT, ou seja, havíamos finalmente começado a tirar mercado de outros destinos, e não só, como no passado, crescido vegetativamente era necessário termos um instrumento muito mais refinado e elaborado a mão. $\mathrm{E} o$ Plano Aquarela seria este instrumento.

O perfil da Embratur antes da criação do Mtur não permitia que a entidade tivesse foco no turismo internacional. Uma das conseqüências desta falta de foco foi que não se conseguia estabelecer uma linha de ação que fosse conseqüência de uma estratégia desenhada para as necessidades do Brasil como destino turístico mundial.

As ações da Embratur no mercado internacional estavam marcadas pela descontinuidade e por atividades isoladas, que não compunham um mix de marketing consistente e regular, capaz de gerar impacto no mercado. 
Tudo isso era decorrência do desenho institucional como pano de fundo e, na prática, da ausência de planejamento financeiro que desse sustentação a uma estratégia de longo prazo.

Resolvido o problema da atribuição institucional, após a redefinição de foco decorrente da criação do Ministério de Turismo e do planejamento dos recursos, restava um problema técnico a ser resolvido: qual o posicionamento, qual o branding que Brasil teria que promover no mercado internacional do turismo?

A resposta a estas questões foi dada pelo Plano Aquarela - Marketing Turístico Internacional do Brasil, concebido pela equipe técnica da Embratur, orientada por uma empresa de consultoria de longa experiência no mercado turístico nacional e internacional, a Chias Marketing, tendo sido no seu bojo contratado o maior conjunto de pesquisas já realizadas sobre a imagem do Brasil como destino turístico internacional.

A atividade turística não acontece sem a participação dos diversos setores que o compõem. O Plano Aquarela é um instrumento que impacta todo o setor, portanto não poderia ser realizado à revelia dos segmentos que o integram. Desde o primeiro momento foi desenvolvido com um viés fortemente participativo. Trabalharam nele técnicos da Embratur, entidades do setor turístico, técnicos de áreas correlatas como o Instituto Brasileiro do Meio Ambiente e dos Recursos Naturais Renováveis (Ibama) e o Instituto do Patrimônio Histórico e Artístico Nacional (Iphan), governos municipais, estaduais, entidades e empresas para definir o diagnóstico que orientaria todas as estratégias e em conseqüência, o programa de ações que comporiam o Plano Aquarela - Marketing Turístico Internacional do Brasil.

Realizamos atividades extremamente interessantes e igualmente inéditas. Inicialmente, elaboramos um questionário com dezenas de questões a respeito do país, capaz de compor um cenário extremamente rico dos temas ligados direta e indiretamente ao turismo. O questionário abrangia temas ligados a destinos, cultura, custos, serviços, transportes, alimentação, hospedagem, imagem, segurança, enfim, item a item, procurando entender tudo o que ajudava e tudo o que atrapalhava a promoção e a venda do Brasil no exterior.

Reuniões de debate e questionamento foram feitas em primeiro lugar no Brasil, com todo o setor de turismo. Mais de uma centena de pessoas, entre presidentes de 
entidades, dirigentes de empresas, autoridades regionais e locais, lideranças de segmentos estratégicos e profissionais de atividades correlatas, foram ouvidos para se obter a primeira linha de opiniões - como o turismo brasileiro via a si mesmo e a nosso país. Incluímos aí também as primeiras questões que objetivavam iniciar o processo de criação da Marca Brasil: perguntamos quais eram as cores e as formas do país. Os resultados ainda nos dariam, por mais científicos que fossem os processos de avaliação, alguma dor de cabeça.

Encerrada a primeira fase, iniciamos a realização de pesquisas, com o mesmo questionário, em 18 países, com o mercado turístico. O universo foi composto por operadoras que já vendiam e as que não vendiam o "produto" turístico Brasil. Nesta fase, foram entrevistados, em cada um dos 18 países, as 10 maiores operadoras de turismo emissivo, sendo que obrigatoriamente, as cinco primeiras da lista eram as de maior volume de vendas, e as cinco seguintes, tinham que, obrigatoriamente, ter o Brasil na sua relação de produtos disponíveis ao mercado.

A terceira fase foi ouvir a opinião dos clientes, nos mesmos 18 países, e no Brasil. Foram entrevistadas seis mil pessoas, sendo parte no país e parte no exterior. O universo composto pelos turistas se dividia em dois perfis de público: os que não conheciam e os que já conheciam o Brasil, sendo que a segunda categoria foi de extrema importância para subsidiar a construção da imagem e do posicionamento do Brasil como produto turístico.

Reunidas as três fontes de informação, o grupo técnico entrou em atividade de análise, formulação, debate e organização final do material, tendo por objetivo apresentar um plano que compusesse um programa de trabalho capaz de nortear as ações de promoção e marketing turístico do País por pelo menos uma década.

Concluído e apresentado à sociedade o Plano Aquarela, tivemos algumas definições fundamentais:

- Posicionamento: A principal razão pela qual os clientes vem ao Brasil são seus recursos naturais. A principal razão pela qual, após alguns dias de permanência, se surpreendem com país, está nos resultados de seu contato com a população brasileira, na qualidade e na diversidade cultural que por aqui encontram, representada destacadamente pelas diversas manifestações com as quais tem 
contato - gastronomia, musica, arquitetura, hospitalidade e moda, destacadamente;

- Mensagens e produtos principais por mercado: O relatório final do plano identifica claramente uma diferenciação entre as mensagens e produtos a serem apresentados aos diferentes mercados. Por exemplo, fica claro que, enquanto na Europa ibérica, o segmento sol e praia segue destacado, na Ásia, o segmento atrativos naturais, com destaque para a Amazônia, Pantanal e Iguaçu seria o nosso novo carro chefe. Definimos cinco eixos de trabalho - natureza, cultura, esportes aventura, negócios e eventos e o tradicional sol e praia;

- Marca/slogan: Obtivemos todos os insumos necessários para definir como deveria ser a marca de promoção turística do Brasil, assim como seu slogan, que acabamos definindo ao optar pela palavra e pelo conceito - Sensacional!;
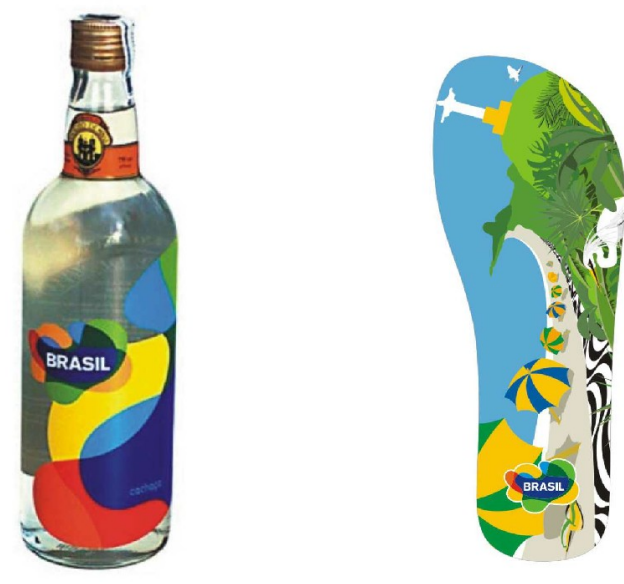

Figura 5 - Produtos da Marca Brasil

- Definição de concorrência: As pesquisas nos possibilitaram definir quais são os nossos concorrentes em cada região e para cada segmento. Esta informação foi fundamental para começarmos a investir no que era realmente prioritário e eficaz, possibilitando-nos rever certas práticas e agendas que vínhamos implementando;

- Definição de mercados prioritários: Definimos os 16 mercados prioritários para o turismo brasileiro, na América Latina, na Europa, na América do Norte e na Ásia;

- Principais linhas de ação e levantamento de desejos dos clientes (intermediários e finais): As principais linhas de ação são as que estamos explicitando aqui neste trabalho. Cada programa da Embratur foi redimensionado a partir das definições do 
Plano Aquarela, assim como novos programas foram implementados visando atingir as metas propostas;

- Estabelecimento de metas por mercado: Para cada mercado, estabelecemos uma meta quantitativa de ingresso de passageiros, de recursos, e um volume de investimentos a serem realizados em programas de trabalho e ações de mídia.

Do Plano resultou a maior campanha de marketing e comunicação já realizada pelo Brasil no exterior. Ele orientou as ações, a nova linha de comunicação e, conseqüentemente, o novo posicionamento e imagem estabelecidos para o Brasil como destino turístico. E, na medida em que começa a gerar uma mudança de percepção dos públicos intermediário e final com relação aos produtos que apresentamos ao redor do planeta, nos possibilita avaliar com dados e fatos, os resultados de cada etapa.

Com base nessa premissa, o plano prevê sua própria atualização a cada dois anos, incluindo aí o monitoramento da evolução da imagem do país junto aos seus consumidores e à captação de desejos destes em relação ao Brasil. As pesquisas realizadas tem sua nova série prevista para 2007, para que os dados não envelheçam e o país não perca a série histórica, dado mais importante para a gestão de imagem do Brasil.

As técnicas de marketing adotas pelo Plano Aquarela - Marketing Turístico Internacional do Brasil respaldam o objetivo de converter o Brasil em um destino turístico competitivo internacionalmente, já que os seus concorrentes as utilizam há muito tempo. Tendo em vista o ineditismo do programa no país, este plano de marketing, agregado ao potencial dos produtos turísticos, pretende colocar o Brasil em lugar de destaque na mente do consumidor.

\subsection{MíDIA}

Ao contrário dos seus principais concorrentes, o Brasil não tem uma história de presença marcante na mídia paga de seus principais mercados-alvo.

Esta situação explica, em parte, porque o nível de desejo e conhecimento do 
país é grande, mas muito aquém do seu potencial.

A primeira conseqüência do Plano Aquarela - Marketing Turístico Internacional do Brasil foi criar uma ampla campanha com veiculação dirigida ao público-objetivo que faz viagens de longa distância pelo mundo, público este estabelecido pelo próprio Plano.

As peças obedeceram ao novo posicionamento estratégico e focaram um aspecto muito levantado nas pesquisas: quem conhece o Brasil se encanta. O slogan criado para esta campanha "Quem vem vira fã" ressaltava a maior qualidade apontada pelos clientes: a capacidade que o Brasil tem de encantar e fidelizar o turista internacional. Uma relação emocional, que beira a paixão.

A linguagem gráfica desenvolvida para esta campanha está baseada no conceito estabelecido pelo plano e pela Marca Brasil, que foi criada sob à orientação do próprio plano. Composta por imagens de lugares sensacionais do Brasil, apontados pelo plano como produtos turísticos com capacidade de promoção internacional e apoiada no conceito geral, Brasil Sensacional!, a campanha utiliza turistas que realmente visitaram o Brasil e têm seus rostos pintados com as partes que formam a Marca Brasil, fazendo uma alusão ao fã, que pinta o rosto e veste a camisa.

Esta campanha, com duração de dois anos, começou em 2005 e tem as seguintes variáveis em sua estratégia de mídia:

- Utilizar a boa relação cambial com os vizinhos para afirmar a liderança do Brasil na América do Sul, comprando um volume muito agressivo de presença em mídia paga;

- Reposicionar a imagem do Brasil na América do Sul, que estava muito associada a preços baixos e qualidade questionável;

- Facilitar o trânsito editorial com os veículos a partir de uma boa relação comercial na América do Sul;

- Focar os investimentos fora da América do Sul em públicos muito bem definidos para evitar dispersão, por causa dos altos custos e do problema cambial;

- Evoluir para compra de mídia em mercados que têm papel duplo: mercado prioritário e formador de opinião (já que não há recursos para tudo);

- Garantir continuidade das ações, realizando compras de mídia de no mínimo 6 meses, garantindo freqüência, já que é uma estratégia de formação de imagem, não 
de venda de produto que poderia focar na alta temporada para proporcionar vendas a curto prazo;

- Utilizar sempre pesquisas confiáveis de hábitos de mídia para desenhar as estratégias locais;

- Validação da compra de mídia nos mercados locais, especialmente nos comitês de venda do Brasil, para garantir apoio e multiplicar os recursos com a adesão de parte da iniciativa privada, formando um cooperado rudimentar.

A campanha de comunicação "Brasil. Quem vem vira fã!" foi a maior campanha de publicidade realizada para o Brasil como destino turístico no mercado internacional. Embora esta seja uma ferramenta amplamente utilizada pelos competidores, da mesma maneira o Brasil precisava utilizá-la, pois não podíamos deixar de estar fortemente presente na mídia dos mercados estabelecidos como prioritários e disputar espaço na cabeça e no desejo do consumidor.

Os resultados de uma campanha desta envergadura somente podem ser aferidos depois de dois anos de ação. No entanto, na América do Sul e em Portugal houve retorno imediato, inclusive com impacto sobre as vendas, com relatos de operadores no Chile e na Argentina. Porém, a melhor forma de medir os resultados será através das novas pesquisas qualitativas e quantitativas que serão desenvolvidas na reavaliação do processo ao longo de 2007 para entender os resultados tangíveis e os não tão tangíveis, como, por exemplo, mudança e evolução de percepção.

Estrategicamente, era indispensável realizar uma campanha de mídia, pois publicidade é uma ferramenta de comunicação fundamental para construção de um posicionamento em relação aos competidores no imaginário do consumidor. Também é preciso levar em conta que a "imagem" é um recurso essencial na promoção de destinos turísticos, já que é um instrumento decisivo para gerar desejo e seduzir o turista.

Apesar da sua eficiência, não se pode perder de vista que publicidade é uma ferramenta de comunicação custosa, embora indispensável dentro da estratégia global. O grande desafio da Embratur era desenvolver uma mídia eficiente, dentro do orçamento disponível. 


\subsection{Brasil Network - Programa de Relacionamento do Turismo Brasileiro}

O Brasil tinha tradição de participar das feiras de turismo internacional, até com presença agressiva em alguns momentos. No entanto, acabada a feira, o país não mantinha um relacionamento e não possuía estratégia de comunicação para o pré e pós-feiras. A curva de relacionamento descia a níveis inaceitáveis. Logo, o relacionamento do Brasil com o mercado turístico internacional era como uma área permeada por picos e vales.

As pesquisas realizadas com o setor profissional, que intermedeia o negócio do turismo internacional, no atacado e no varejo, deixavam claro como queixa recorrente que o maior problema do Brasil era a ausência de informações. Este fato foi recebido com alguma surpresa pelo mercado do turismo brasileiro, já que se imaginava que o maior problema do Brasil estava associado a temas como a violência e a pobreza. Ou seja: a maior deficiência de imagem do Brasil nos canais de comercialização era a ausência de informação e, conseqüentemente, de imagem, fato que se confirmou com as pesquisas realizadas pelo Plano Aquarela.

A partir deste diagnóstico foi construído um programa de relacionamento entre o Brasil e estes clientes profissionais - operadores e agentes de turismo do mercado internacional que se interessam pelo Brasil.

A idéia foi criar um site, integrado ao Portal Brasileiro de Turismo, que disponibilizasse informações precisas sobre o país como destino turístico, dirimindo dúvidas relativas a todos os fatores de decisão de viagens - objetivos (clima, segurança, acessibilidade) e subjetivos (imagem, grau de desejo, posicionamento no imaginário do cliente).

Além do relacionamento passivo (oferecer informação e esperar que o cliente a busque), o programa também desempenha papéis ativos na preparação de outras ações do mix de marketing, como o pré e pós-feiras e eventos e ações de incentivo.

Este programa busca aplacar o maior problema de imagem do Brasil, que é a falta de informação a respeito do país como destino turístico internacional. 
O maior problema deste programa de relacionamento era a distribuição das mensagens em todo o mundo e o custo desta operação. Assim, optou-se por operar uma plataforma na Internet, que permite a veiculação de mensagens multimídias com custo infinitamente menor.

Todo o programa está desenvolvido pela Internet e funciona no botão de profissionais do iwww.braziltour.com.

Após a implantação do Brasil Network - Programa de Relacionamento do Turismo Brasileiro já é possível medir alguns resultados quantitativos:

1. Mudança da percepção do Brasil nas feiras e eventos, já que agora há contato antes e depois dos eventos e feiras. Pelos números de acessos recebidos no site, no banco de imagens e nas ações de comunicação, além dos vários e-mails que recebemos semanalmente pelo canal FaleConosco, pode-se afirmar sim uma mudança da percepção em relação ao Brasil. Muito porque, como já de disse antes, essa percepção não existia;

2. Grande aceitação de recebimento de mensagens - cerca de $10 \%$ do banco de contatos. Ao início de 2006, já ocorria uma aceitação média de $25 \%$ da base (aproximadamente 20.000 cadastros), com permanente comunicação, tais como: newsletter, comunicado de feiras, eventos, negócios, caravanas e ações demandadas pelos EBTs;

3. Ampliação de demanda do banco de imagens on-line: com mais de 600 fotos disponíveis, obtinha há um ano, uma média de 2.000 imagens visualizadas por mês e 200 imagens baixadas (downloads), também por mês. São imagens do Brasil solicitadas por operadoras, agências e imprensa (genérica ou especializada) do mundo inteiro para materiais promocionais, impressos, internet e veículos de comunicação;

4. Ainda como informação, a média mensal de acessos ao site fechou $2006 \mathrm{com}$ 10.000/mês só do Brasil Network. Se quantificamos o Braziltour, há uma média mensal de 500.000 acessos;

5. Aumento em mais de $300 \%$ nos contatos com a área de profissionais, obtido pela facilidade com que este profissional encontra informações: saltamos de cerca de 1.500 no início do programa para quase 5.000 contatos permanentes até hoje. Só 
neste ano, foram mais 150 comunicações via e-mail mkt, das diversas áreas da Embratur para os 18 mercados prioritários.

\subsection{Programa de Relações Públicas}

Este é o primeiro case de Relações Públicas (RP) para o setor público. $\mathrm{O}$ programa, recomendado pelo Plano Aquarela, procura, através de estratégias de relacionamento com a imprensa e o público final, gerar e consolidar opinião positiva sobre o Brasil e o Turismo Brasileiro, bem como divulgar o trabalho da Embratur junto aos meios de comunicação internacionais, tanto especializados em turismo quanto na grande imprensa.

O conceito chave de sustentação do programa é a constatação de que, nosso público alvo, alguém capaz de comprar uma viagem internacional partindo de pelo menos 18 destinos do mundo rumo ao Brasil, tem um perfil de consumo que não é levado a tomada de decisões apenas por ações de mídia e propaganda, devendo ter disponibilizados, a tempo e a hora adequadas, acesso a informação, gerada por fonte nas quais ele deposite credibilidade. Ou seja, além de propaganda, era necessário iniciar um programa inédito de relacionamento do Brasil turístico com os meios de comunicação, e destacadamente com os formadores de opinião, pelo menos nos mercado-alvo.

A partir destas premissas, a gerência de Relações Públicas da Embratur, vinculada à Diretoria de Marketing, contratou as duas agências vencedoras da licitação realizada no início de 2006:

- FSB - que tem como parceira internacional a agência Ogilvy PR, que atua no Reino Unido, Portugal, Alemanha e Estados Unidos;

- Máquina da Notícia - que tem como parceiras internacionais as agências Estúdio Comunicación e $\mathrm{GCl}$, que trabalham os meios de comunicação da Itália, Chile, Espanha, França, Peru, Argentina e Uruguai.

As agências têm a missão de construir uma relação de confiança e credibilidade 
com os meios; fazer com que a Embratur se transforme em fonte de informação de qualidade sobre o turismo no Brasil para jornais, revistas, rádios, emissoras de televisão etc. Pretendem também dar continuidade à presença do Brasil na mídia, consolidando a opinião positiva e, a médio prazo, reduzir esforços e custos de posicionamento e publicidade nos mercados.

Para cumprir esses objetivos, mantêm, através das agências e também dos EBTs, uma maior presença nos mercados indicados, com fornecimento de informação relevante e qualificada. A cada situação, é feita uma definição de porta-vozes, com a parceria da Ascom - Embratur.

São diversas as ações. Uma delas merece destaque: são os Press Trips próativos, em que jornalistas da grande imprensa internacional especializados em turismo e áreas afins - como gastronomia, música, moda, esportes radicais -, são convidados a realizar viagens ao Brasil. Os roteiros são especialmente desenhados, conjugando os interesses estratégicos do Brasil no mercado em questão - apontados pelo Plano Aquarela - e a expectativa do profissional. O jornalista é acompanhado por um profissional designado pela agência contratada, que faz posteriormente todo o acompanhamento pós-viagem: fornecimento de informações complementares, clipping da publicação das matérias etc. Esse trabalho é feito em parceria com a Gerência de Apoio à Comercialização, que trata de toda a parte operacional.

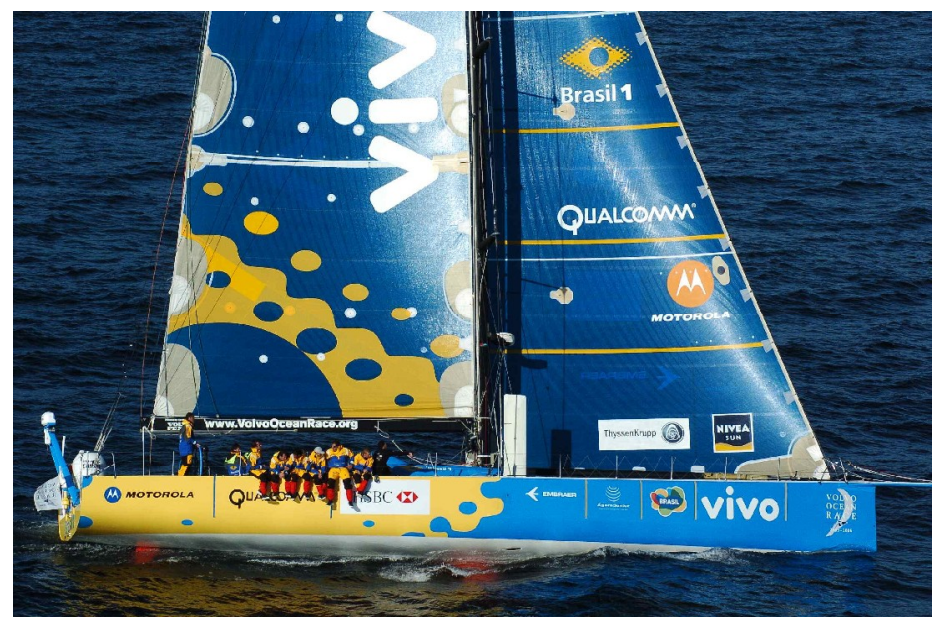

Foto 10 - Ação de Promoção de Competição Internacional de Vela em 2006 
Para ajudar na elaboração e planejamento das ações de RP, a Embratur realiza o monitoramento e análise da presença e desempenho do Brasil na mídia internacional, através do Monitor Brasil, uma ferramenta especialmente desenvolvida para o Instituto. Analistas (jornalistas qualificados), em 11 países, enviam diariamente comentários, com pontuação, sobre o impacto das notícias publicadas sobre o país nos mercados. O critério adotado para pontuar é: o quanto a informação influi na decisão do leitor em viajar/conhecer o Brasil. Eles analisam as publicações nos principais meios da grande imprensa, formadores de opinião. O Monitor serve também como "auditor" e “mensurador" das ações da Embratur nos mercados.

Em 2006, o primeiro semestre do programa foi dedicado aos seguintes eventos internacionais:

- a feira ITB, em Berlim (Alemanha);

- a mostra Tropicália - a Revolution in Brazilian Culture, no Centro Cultural Barbican, em Londres (Reino Unido);

- o International Food Festival - United Nations Delegates Dining Room, na sede da Organização das Nações Unidas (ONU), em Nova York (Estados Unidos);

- a feira Salón Internacional de Turismo (SIT), em Lima (Peru);

- o Rock in Rio Lisboa, em Portugal;

- e a Copa do Mundo 2006, na Alemanha.

No segundo semestre, a relação com os meios de comunicação, principalmente os que são monitorados através da ferramenta Monitor Brasil, foi aprofundada. Houve continuidade das press trips e relacionamento com os meios e com os correspondentes estrangeiros no Brasil. Os projetos principais do período são:

- o programa Embratur 40 anos, que percorreu cinco capitais com exposição, seminários e vídeos;

- o início das ações de relacionamento diretas com os turistas estrangeiros (foi realizado em Florianópolis, em setembro, o $1^{\circ}$ Seminário de Relacionamento com o Turista Estrangeiro, no qual foram levantadas as informações para a produção, em breve do Guia de Relacionamento com o turista estrangeiro);

- o mapeamento e atualização de guias de viagem;

- idem em relação às publicações de bordo produzidas por empresas aéreas nos 
mercados prioritários.

No final do ano, por conta da repercussão do filme norte-americano Turistas, rodado no Brasil - em que um grupo de jovens em férias acaba vítima de uma quadrilha de tráfico de órgãos na selva amazônica, a Embratur aproveitou a polêmica para transformar um possível dano à imagem do país em algo positivo, utilizando a evidência do país na mídia para divulgar suas belezas. Todo o processo de repercussão do filme tem sido acompanhado pelo Monitor Brasil, assim como pela agência de RP nos Estados Unidos.

Procedimento semelhante foi adotado no primeiro ano de gestão, quando não havia ainda nem um Plano de Marketing consolidado. No dia 30 de novembro de 2003, no Rio de Janeiro, foi assassinado o casal norte americano Todd e Michelle Staheli. Por ser ele diretor de gás e energia da Shell, e pela brutalidade do crime - o casal foi morto com uma espécie de machadinha, o fato ganhou repercussão internacional. Como não se descobriu logo o assassino, o crime ocupou grande espaço na mídia, em especial a norte-americana, associando ao Rio de Janeiro a imagem de uma cidade extremamente violenta. Para amenizar isso e ter um mínimo controle sobre as informações que eram veiculadas, a Embratur criou um Gabinete de Crise, o qual chamou outras áreas do governo afins, como a Secretaria de Comunicação (Secom) e - Ministério da Justiça. Passamos a monitorar e auxiliar todas as autoridades brasileiras, naquele momento porta-vozes do episódio. Unificamos o discurso de todos para que não existissem informações desencontradas. Um dos resultados deu-se em uma matéria da agência Reuters, divulgada nos Estados Unidos. Nela, afirmava-se que o Rio de Janeiro seria uma das cidades mais violentas do mundo. Não havia qualquer menção à origem dessa informação. Por meio desse Gabinete, contratamos uma agência de RP nos Estados Unidos que, in loco, questionou a informação da agência de notícias. Pedimos que a Reuters informasse qual fonte, pesquisa ou declaração sustentava aquele dado. Como isso não existia - a agência irresponsavelmente afirmara algo do qual não tinha provas - a notícia foi prontamente corrigida.

Queria aqui aproveitar para reafirmar minha crença de que é possível encontramos soluções para a crise que atravessa o Rio de Janeiro. Os reportes diários sobre atos de violência naquela cidade, assim com de resto em todo o país, podem e 
devem ser enfrentados com todo o rigor. Eu creio que esta deve ser uma prioridade para o segundo mandato do Presidente Lula, assim como uma prioridade para os governos estaduais recém empossados.

\subsection{Programas da Assessoria de Comunicação}

A Ascom, que responde diretamente à presidência, tinha dois desafios a partir do redesenho da Embratur. Com 36 anos de história, era necessário o reposicionamento da "marca" Embratur, até aquele momento sinônimo de classificação de hotéis, credenciamento de guias, adesivos de ônibus de excursão etc. Enfim, era preciso alterar uma marca de governo que durante décadas representou qualquer ação pública de turismo na esfera federal e transformá-la - para a imprensa - numa agência de promoção comercial do Brasil no exterior. Era tarefa dupla, já que a própria promoção lá fora já era exercida pela Embratur por todos este anos, sem a dimensão nem os resultados que agora nos propúnhamos a alcançar.

É importante entender que o principal negócio da Embratur a partir de então não é mais o turismo propriamente, mas a comunicação do produto Brasil. Desta maneira, a Ascom tem função estratégica na divulgação dentro do Brasil das ações de promoção lá fora, buscando, mais do que informar, qualificar o que está sendo veiculado.

Este é, então, o segundo desafio: qualificar a informação, mostrando de forma objetiva as ações e - principalmente - os resultados da promoção do Brasil. Como eles podem ser mensurados? Como estas informações podem ser passadas para a mídia como resultado concreto de uma ação?

O primeiro passo foi criar uma rede de informação entre os órgãos de turismo em todo o país. Conversar com as assessorias de todas as entidades, CVBs, agências, companhias e, principalmente, com as secretarias de turismo dos estados e das capitais. Criar uma capilaridade em todos os meios do setor turístico, fazendo com que eles passassem a trabalhar a partir de uma nova concepção de gestão. Esse ato, considerado simples em qualquer estratégia de comunicação, não é tão comum em 
órgãos públicos. Foram visíveis as falhas dos canais de comunicação existentes entre tantos órgãos. E também uma clara percepção, ainda vigente, das ações de marketing (leia-se publicidade e propaganda) sempre se sobreporem às ações de imprensa. Inúmeras assessorias eram (e são até hoje), compostas por uma única pessoa, que responde por outras atividades. Isso significa, na prática, a pouca atenção que é dada à área e o quanto ações ali desenvolvidas terão quase que nenhuma repercussão.

Diagnosticada esta situação, passamos a alimentar de forma regular estas assessorias com press releases e, principalmente, com dados de turismo que pudessem ser trabalhados por cada um deles, levando em consideração as peculiaridades locais.

Uma mudança de mentalidade vem com o posicionamento que a Embratur dá ao modo de aferição de seus resultados. A partir de 2004, por meio do trabalho da diretoria de estudos e pesquisas, três indicadores passam a balizar os resultados da gestão conforme já mencionamos anteriormente:

- o volume mensal do ingresso de dólares por turistas, medido pelo Banco Central;

- o desembarque de passageiros em vôos internacionais, controlado pela Infraero;

- e a entrada de turistas estrangeiros, este anual.

Importante perceber que apenas o último era um dado já utilizado comumente pela Embratur. Tanto o ingresso de dólares como o número de desembarques eram informações disponíveis, mas que jamais haviam sido trabalhadas. Isso significa que não se fazia o recorte destes dados sob o ponto de visto do turismo. O caso mais emblemático é o de desembarques, pois a própria Infraero não se utilizava deles para medir resultados. A permanente divulgação desses números passou a alimentar tanto a imprensa como as assessorias de forma extremamente positiva: a Embratur transformou-se na fonte de informação, embora estes dados não fossem gerados a partir dali. Isso foi fundamental para criar essa "marca Embratur", focada em resultados e que, a partir daquele momento, tinha como único objetivo a promoção do Brasil no exterior. Quem mais se apropriou destes dados foi a imprensa de economia, até então pouco familiarizada com as atividades da Embratur.

Apesar deste esforço, era nítido que os cadernos de economia (incluindo aí rádio e televisão) ainda não tinham uma compreensão mais clara do papel que o turismo 
passava a desempenhar na economia brasileira. As matérias ainda eram tímidas e muitas vezes apenas reproduziam os números, sem qualquer análise mais aprofundada.

Em junho de 2005, a Ascom - Embratur, assumindo também um papel protagonista em seu segmento de atuação, realiza em Brasília, o $1^{\circ}$ Encontro dos Assessores de Imprensa dos Órgãos de Governo dos CVBs. A intenção foi justamente aproximar, durante um dia e meio, todos aqueles que tinham papel fundamental na divulgação das ações de promoção do turismo, criando um canal direto e equalizando as informações. Este encontro, que teve a participação de quase 50 assessores, foi a origem de um projeto maior, que se chamou $1^{\circ}$ Curso de Economia e Turismo para Jornalistas.

Com o objetivo de qualificar e ampliar o espaço do turismo no jornalismo econômico, foi desenhado um projeto que percorreu, durante oito meses, as vinte maiores capitais brasileiras. $\mathrm{O} 1^{\circ}$ Curso foi desenhado pela Ascom e operacionalizado pelo Núcleo de Estudos de Turismo da FGV (FGV), do Rio de Janeiro. Durante um dia, os principais profissionais de mídia nas áreas de economia e turismo daquele estado (em uma média de 20) reuniam-se com um profissional da FGV, onde discutiam - por meio de conceitos econômicos - como o turismo impactava um destino e como era possível, a partir dos dados disponíveis, pensar matérias que levassem a uma maior compreensão desse impacto. A programação incluía a apresentação do presidente da Embratur, de algum técnico do órgão, e de um jornalista de fora, que discutia com eles as dificuldades do dia-a-dia na redação para emplacar uma matéria naqueles moldes e como os dados ali expostos poderiam ser melhor aproveitados pelos veículos.

O resultado do curso foi surpreendente em vários aspectos. Poucas vezes estes profissionais tinham participado de projeto semelhante. Uma instituição como a FGV indo até eles, um curso gratuito, e a disponibilização de dados e "novas" fontes era, a princípio, algo sempre bem-vindo. Cada cidade tinha suas peculiaridades e, portanto, realidades e necessidades distintas. O curso serviu, antes de tudo, como a oferta de dados para inúmeros veículos do país (a participação total foi de 400 jornalistas) e para discussão de uma realidade sentida por muitos, mas que até então tinha pouca aferição. Por ter sido quase que um projeto piloto, e de realização tão recente, não é 
possível aferir qualitativamente o impacto na cobertura dos termos ligados ao turismo nesses veículos de comunicação. Entretanto, é crescente o números de matérias econômicas em que o turismo já está inserido e apresenta abordagens mais aprofundadas.

Outro diferencial foi a integração entre as áreas de marketing e de comunicação a partir de 2006, com a contratação pela diretoria de marketing das duas agências de RP mencionadas no item anterior. Com elas, foi possível ampliar um trabalho de divulgação nacional, chegando-se aos veículos menores, regionais e mais especializados. A Ascom não tinha, até aquele momento, musculatura para produzir e gerar notícias para além dos principais veículos de cada estado brasileiro. Um programa como a Caravana Brasil, por exemplo, estava constantemente presente nos estados e a cobertura disso não era satisfatoriamente realizada localmente. Com as agências, passamos a conseguir uma divulgação melhor e, mais que isso, passamos a fazer com que os interlocutores dessas ações fossem profissionais dos meios beneficiados, como hoteleiros, agentes de viagens e pequenos empresários locais. Desde o início do ano vem sendo desenvolvido este trabalho, de resultados ainda pouco visíveis, já que isso não é uma prática comum e não é de fácil mensuração. O objetivo aqui é que os verdadeiros beneficiados destas ações sejam os protagonistas de todos os projetos da Embratur.

Uma outra ação importante, esta realizada por mim desde o Anhembi, que presidi de janeiro de 2001 a janeiro de 2003, foi uma forma de prestação de contas pública das ações das equipes que dirigi. Mensalmente, enviava para profissionais do setor e qualquer pessoa que tivesse, de alguma forma, ligação com o turismo, uma breve carta que intitulei "Caros Amigos".

Nela, reproduzida abaixo, resumia as principais ações e resultados dos programas em andamento. Era um texto curto, simples, às vezes com alguma matéria de jornal anexada, onde o destinatário tomava conhecimento do que fazíamos. Chamo isso de uma prestação de contas porque não era comum na Embratur, assim como em outros órgãos públicos, um permanente canal de comunicação que transmitisse, de forma clara, para o seu público (mercado) o que vinha sendo feito no órgão. É importante frisar que todas as informações ali contidas eram de ações já em 


\section{andamento, sem qualquer tipo de "discurso" ou "promessa". Isso criou um hábito, a meu ver, muito saudável no mercado e na sociedade, que passou a se utilizar dessas informações para o seu próprio trabalho.}

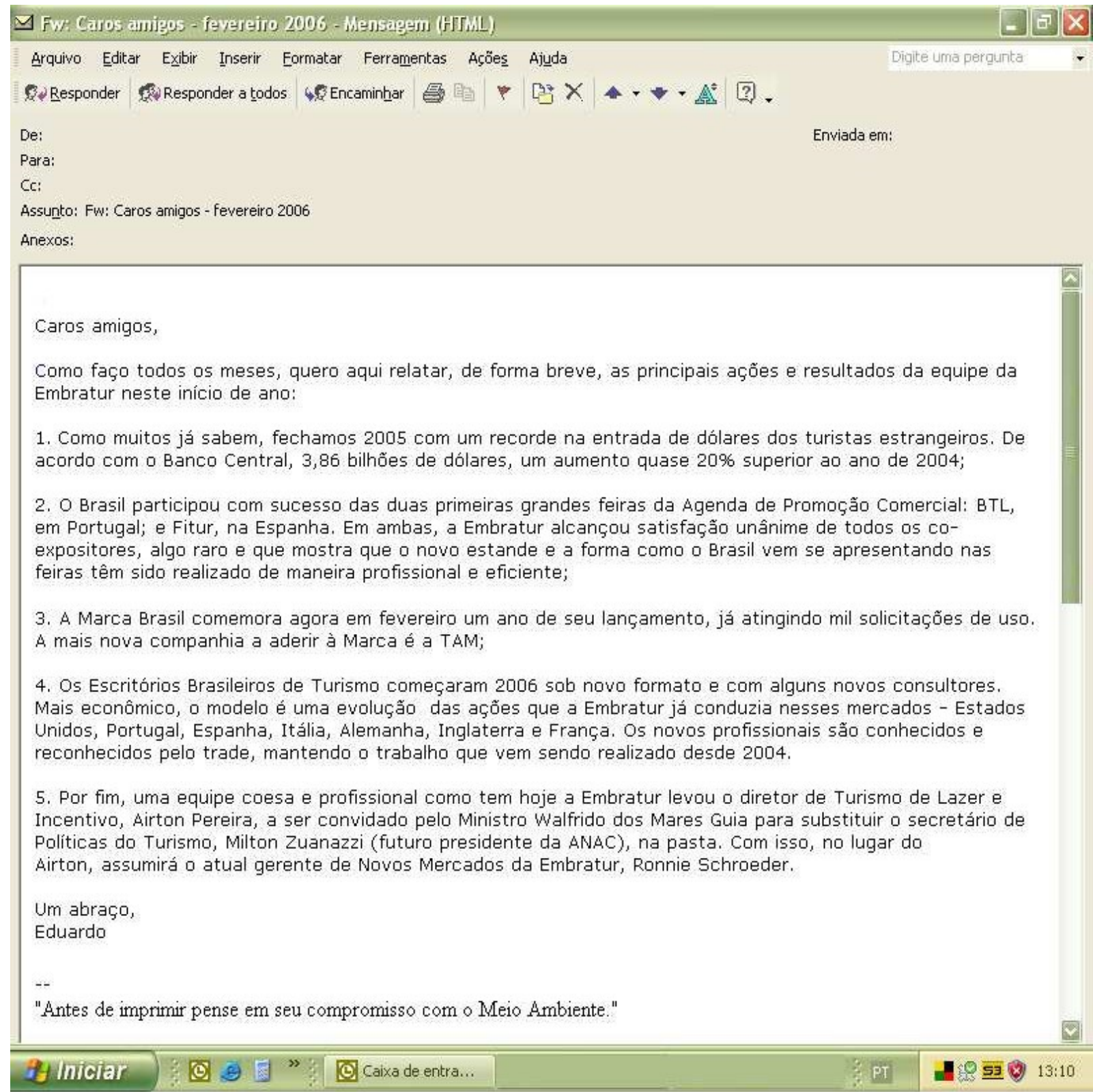

\section{Figura 6 - Caros Amigos - Fevereiro}




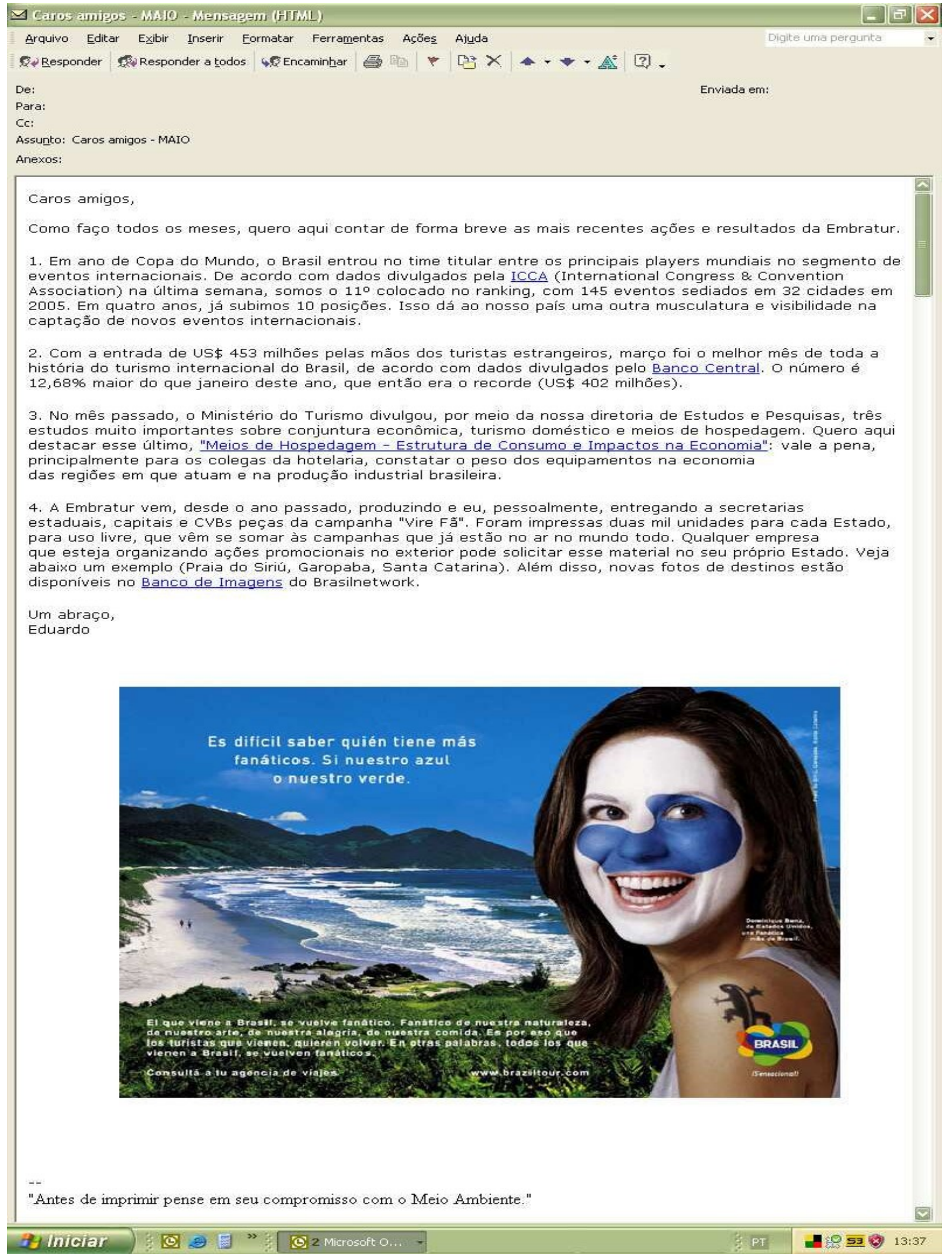

Figura 7 - Caros Amigos - Maio 
Esta prática originou outro hábito a partir de 2005: a divulgação para a imprensa, semanalmente, da agenda dos profissionais da Embratur. Os veículos do trade passaram a publicar, de forma detalhada, as atividades em que a Embratur estava presente ao redor do mundo. Era mais um instrumento disponível para o profissional do turismo se apropriar e usar no seu cotidiano.

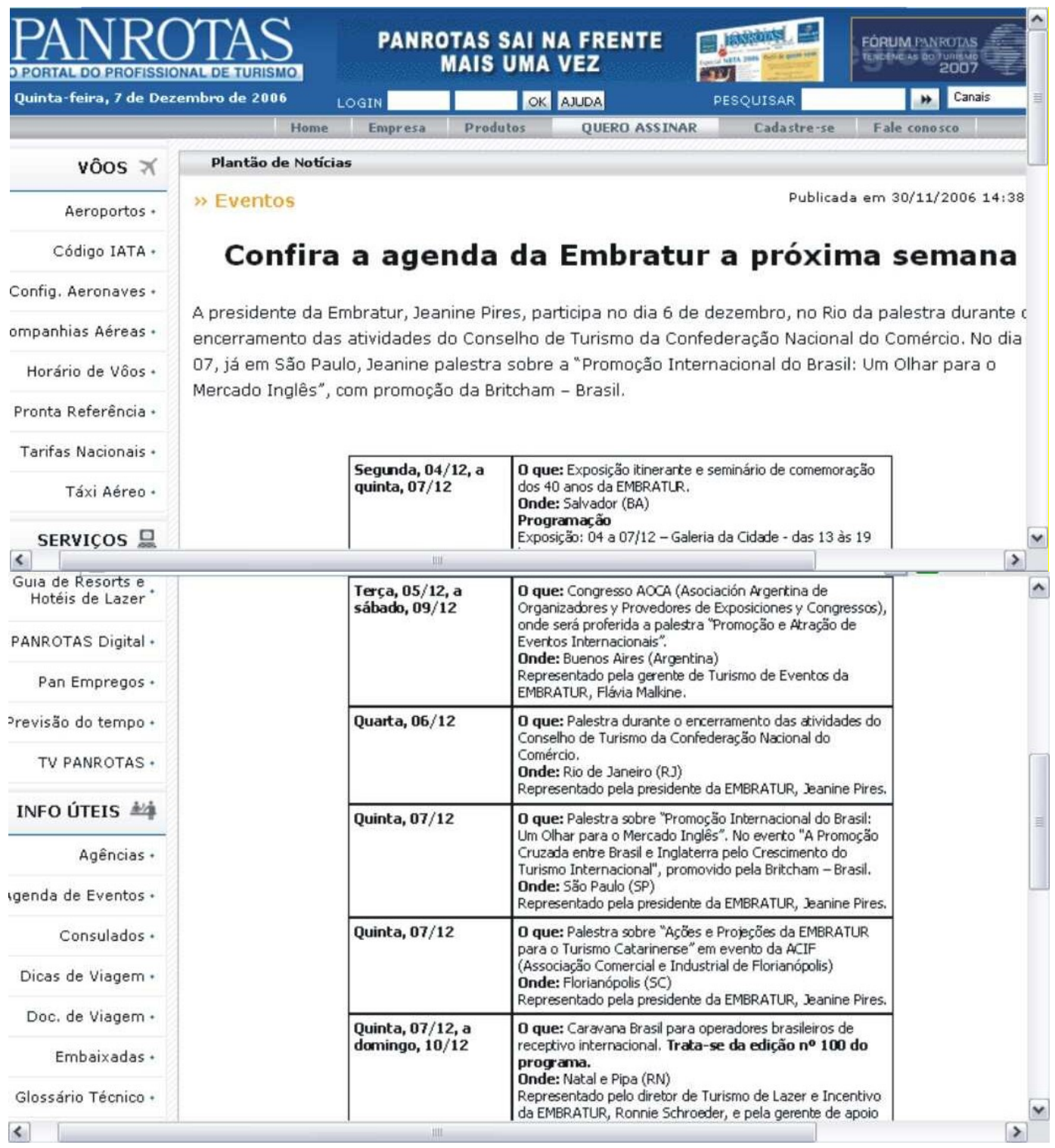

Figura 8 - Panrotas 


\section{ESTUDOS E PESQUISAS}

A área de estudos e pesquisas da Embratur era, até 2002, uma gerência da diretoria de marketing, focada na produção de dois estudos: Demanda Turística e Anuário Estatístico. Como o novo papel da Embratur, há a compreensão da necessidade de se criar um banco de dados confiável do turismo brasileiro, que possa servir para a tomada de decisões, tanto dos agentes públicos como da iniciativa privada. Até então, o quadro técnico da área era pouco qualificado, além de contar com baixíssimo orçamento, o que chegou a acarretar, por exemplo, a paralisação de repasses para o DPF que recebia recursos da Embratur para fazer a digitação das fichas de entrada de estrangeiros.

O primeiro passo, portanto, foi dar o status de diretoria à área, investindo na formação de um corpo técnico qualificado e buscando nas instituições de referência em pesquisas, como FGV e Fundação Instituto de Pesquisa (Fipe), parcerias para a realização de pesquisas que de fato servissem de parâmetro para mensurar a atividade do turismo no país.

Com isso, foram definidos os focos da nova diretoria:

- Elaborar, compilar, avaliar e difundir dados estatísticos relativos a atividade no Brasil;

- Realizar estudos e pesquisas que propiciassem o conhecimento do comportamento e das tendências do turismo internacional e suas repercussões no mercado nacional;

- Implementar um sistema de informação turística que reunisse, sistematizasse e disponibilizasse informações fidedignas e confiáveis sobre a atividade turística com ferramenta de apoio à tomada de decisão do setor privado e a definição de políticas públicas para o setor.

A Diretoria de Estudos e Pesquisas desenvolve um conjunto de programas de trabalho, entre elas pesquisas periódicas, estudos econômicos não-regulares, e compilação e registro de dados periodicamente divulgados por instituições a nós relacionadas. A seguir, passamos a explicar, detalhadamente, cada uma destas pesquisas, sua metodologia de execução, quem são seus executores e os conceitos 
que nos levaram a formular cada uma delas.

\subsection{DEMANDA TURÍSTICA INTERNACIONAL}

Entidade Executora: Fipe

Apoio: Infraero, DPF, Receita e Órgãos Oficiais de Turismo dos Estados.

A partir de Janeiro de 2004 a pesquisa sobre turismo internacional passou a ser desenvolvida pela FIPE com o objetivo de aprimorar a qualidade das estatísticas disponíveis sobre os fluxos emissivo e receptivo de turistas internacionais do Brasil. Integram este projeto as seguintes pesquisas:

- Caracterização do Perfil do Turismo Receptivo Internacional;

- Caracterização do Perfil do Turismo Emissivo Internacional;

- Contagem Amostral do Fluxo Receptivo de Turismo Internacional;

- Contagem Amostral do Fluxo Emissivo de Turismo Internacional.

O projeto objetiva caracterizar e identificar o perfil sócio-econômico do turismo internacional no Brasil, bem como suas motivações, interesses e comportamento em viagem e características de gastos.

Identificar e quantificar, em relação ao receptivo e ao emissivo, os seguintes aspectos:

- País de residência permanente;

- Regiões, Unidade da Federação (UFs) e Cidades mais visitadas por motivo de viagem ("Lazer" e "Negócios, Eventos e Não Lazer");

- Principais motivos e motivações;

- Meios de hospedagem utilizados;

- Meios de transportes utilizados;

- Permanência média no país;

- Gasto total de suas viagens (país de residência permanente e Brasil);

- Fidelização ao Destino - Intenção de retorno, freqüência de visita ao Brasil e 
preferência de viagem a lazer;

- Opiniões sobre os atrativos e a infra-estrutura turística;

- Perfil sócio econômico do visitante - Grau de instrução, idade e renda.

Entre os aprimoramentos implementados para garantir a melhoria da qualidade do produto final no processo de coleta de dados, tabulação e análise listam-se.

Ampliação da Amostra

Evolução da Amostra a partir de 2000

\begin{tabular}{|c|c|c|c|c|}
\hline Períodos & Acessos & Receptivo & Emissivo & Total \\
\hline \multirow{3}{*}{2000} & Terrestre & - & - & - \\
\hline & Aéreo & - & - & - \\
\hline & Total & 11.711 & - & 11.711 \\
\hline \multirow{3}{*}{2001} & Terrestre & - & - & - \\
\hline & Aéreo & - & - & - \\
\hline & Total & 5.248 & 3.388 & 8.636 \\
\hline \multirow{3}{*}{2002} & Terrestre & - & - & - \\
\hline & Aéreo & - & - & - \\
\hline & Total & 3.212 & 3.066 & 6.278 \\
\hline \multirow{3}{*}{2003} & Terrestre & - & - & - \\
\hline & Aéreo & - & - & - \\
\hline & Total & 4.447 & 2.723 & 7.170 \\
\hline \multirow{3}{*}{2004} & Terrestre & 9.793 & 1.937 & 11.730 \\
\hline & Aéreo & 24.985 & 13.849 & 38.834 \\
\hline & Total & 34.778 & 15.786 & 50.564 \\
\hline \multirow{3}{*}{$2005^{*}$} & Terrestre & 6.381 & 2.503 & 8.884 \\
\hline & Aéreo & 19.349 & 14.970 & 34.319 \\
\hline & Total & 25.730 & 17.473 & 43.203 \\
\hline \multirow{3}{*}{$2006^{*}$} & Terrestre & 6.400 & 1.300 & 7.700 \\
\hline & Aéreo & 18.000 & 6.800 & 24.800 \\
\hline & Total & 24.400 & 8.100 & 32.500 \\
\hline
\end{tabular}

* A partir da experiência de 2004, foi possível, gradualmente, reduzir o tamanho da amostra, - inicialmente prevista para ser realizada com 36.000 elementos -, com base na constituição de grupos homogêneos de turistas, tanto do emissivo quanto do receptivo. $O$ atual dimensionamento pressupõe uma margem de erro de $5 \%$ na estimativa do gasto médio per capita de cada um dos grupos homogêneos. No total, a margem de erro desta proposta para o receptivo aéreo é de apenas $1,3 \%$ e para o terrestre é de $2,1 \%$. 
A amostra praticada em 2003 foi de cerca de 7.000 questionários, enquanto a amostra contratada nos anos seguintes passou a ser de 36.000 questionários.

Em 2004 foram aplicados 50 mil questionários, enquanto em 2005 este número foi de 43 mil.

Esta ampliação no número de observações efetivas aumenta significativamente a confiança estatística dos resultados finais, ou seja, reduz o erro amostral aceito. Além disso, são abertas maiores possibilidades de cruzamentos de variáveis, análises de segmentos específicos da demanda turística, desagregação dos resultados por países de origem dos entrevistados e por local de pesquisa. Assim, aprimora-se a representatividade do universo pesquisado.

\section{Grau de Significância da Amostra}

O dimensionamento da amostra pressupõe uma margem de erro aproximada de $1 \%$ para os dados gerais e de $5 \%$ na estimativa em nível de cidades e UFs.

\section{Controle Amostral}

Um maior controle da amostra efetivada passou a ser aplicado, em especial no que tange à nacionalidade dos turistas estrangeiros que visitam o Brasil. Por meio de técnicas estatísticas avançadas, como os testes Scheffé, Duncan e Dunnett T3, foram criados grupos homogêneos de gastos turísticos por nacionalidade do entrevistado. Desta forma, passou-se a obter um maior nível de confiabilidade dos resultados finais da pesquisa. A formação de grupos homogêneos fornece subsídios para critérios mais apurados de expansão dos resultados finais, otimizando a amostragem efetuada e economizando recursos. Esta metodologia de grupos homogêneos visa, sobretudo, o reconhecimento, por parte do Bacen, das receitas e despesas turísticas internacionais computadas desenvolvidas pela Embratur a partir da presente pesquisa e do número total de turistas internacionais do Brasil.

\section{Ampliação dos pontos de levantamentos}

A pesquisa até 2003 era efetuada em 14 pontos do território nacional, sendo que em 2004 este número passa para 17. Hoje a pesquisa atinge 22 pontos de pesquisa 
com o intuito de garantir maior representatividade nos principais pontos de entrada e saída de turistas listados a seguir:

Aeroportos internacionais (12):

1. Porto Alegre - RS

2. Florianópolis - SC

3. Curitiba - PR

4. São Paulo - SP

5. Rio de Janeiro - RJ

6. Salvador - BA

7. Maceió - AL

8. Recife - PE

9. Natal - RN

10. Fortaleza - CE

11. Belém - PA

12. Manaus - AM

Fronteiras terrestres (10):

13. Chuí - RS

14. Santana do Livramento - RS

15. Uruguaiana - RS

16. São Borja - RS

17. Dionísio Cerqueira - SC

18. Foz do Iguaçu - PR - Ponte Tancredo Neves

19. Foz do Iguaçu - PR - Ponte Internacional da Amizade

20. Ponta Porã - MS

21. Corumbá - MS

22. Pacaraima - RR 


\section{Pontos de Coleta de Dados}

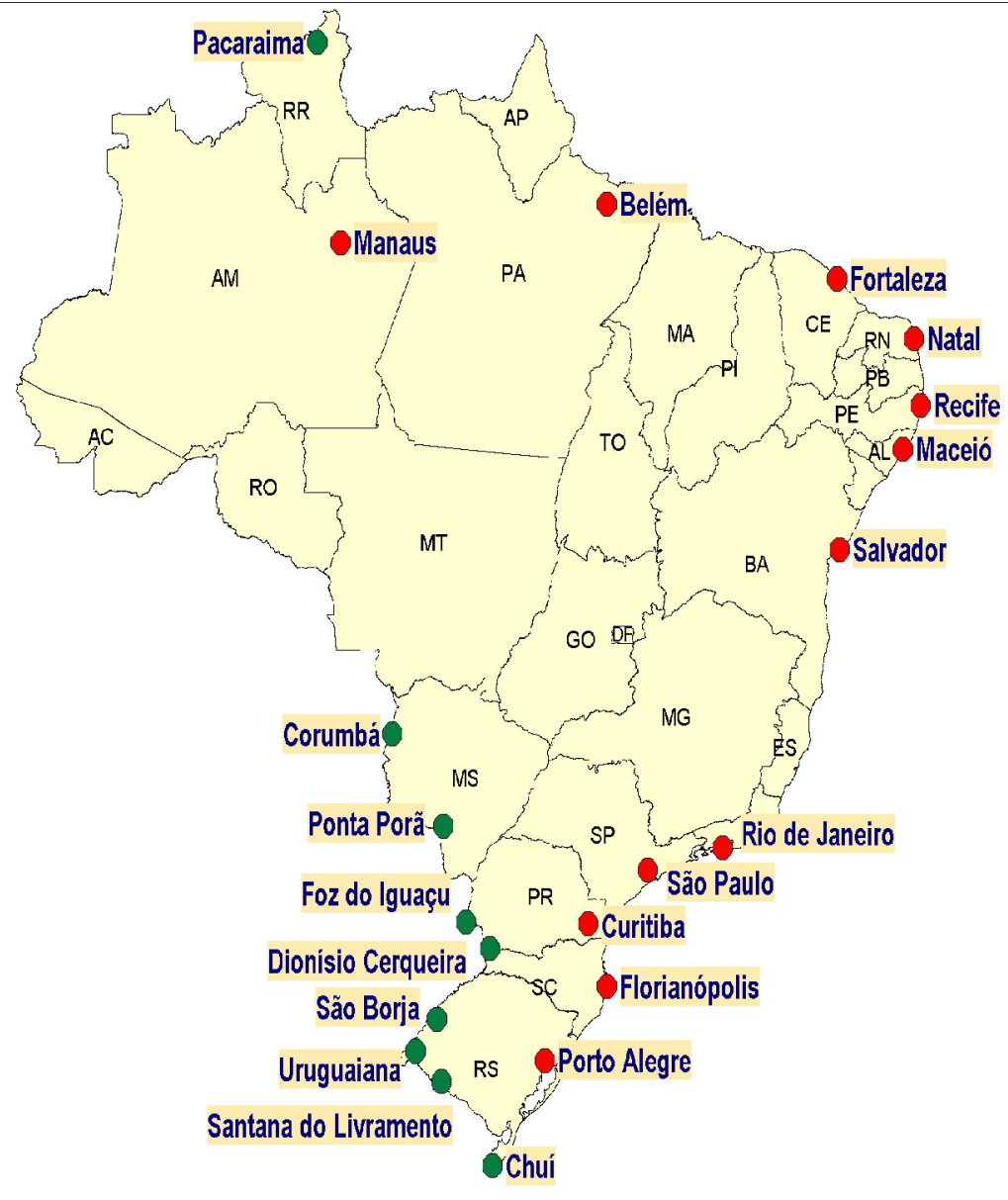

Mapa 1 - Pontos de Coleta de Dados

\section{Aumento do número de etapas da pesquisa}

Até 2003 as pesquisas de perfil do turismo internacional no Brasil eram desenvolvidas em duas etapas por ano. A partir de 2004 estas pesquisas passam a ser desenvolvidas em quatro etapas anuais, com o objetivo de captar o movimento sazonal do fluxo de turistas internacionais receptivos e emissivos do Brasil na alta, média, médio-baixa e baixa estação. Assim, a ampliação do número de etapas de pesquisa privilegiou as estimativas desenvolvidas para localidades que apresentam sazonalidade dos fluxos turísticos internacionais diferentes da média brasileira, como algumas 
capitais do Nordeste e a região Norte.

\begin{tabular}{cc} 
Etapas da Pesquisa e Meses & Correspondentes \\
\hline Alta: & Janeiro \\
Média: & Julho \\
Baixa: & Maio \\
Média-baixa: & Novembro \\
Quadro 9 - Etapas da Pesquisa e Meses Correspondentes
\end{tabular}

\section{Duração das etapas de coleta}

Duas semanas durante as quatro etapas nas localidades de maior fluxo (São Paulo, Rio de Janeiro e Foz do Iguaçu).

Nas cidades de médio fluxo em uma etapa é feito duas semanas e uma semana nas outras etapas (Porto Alegre, Florianópolis, Salvador, Recife, Fortaleza, Chuí, Santana do Livramento, Uruguaiana).

Uma semana nas localidades de menor fluxo (Manaus, Belém, Pacaraíma, Ponta Porã, Corumbá, Dionísio Cerqueira, São Borja, Maceió, Natal e Curitiba).

\section{Aprimoramento da estrutura dos formulários}

Com vistas à padronização e comparabilidade das informações, conforme preconizado pela OMT, os formulários de pesquisa foram reformulados em estrutura e conteúdo. Foram acrescentadas novas temáticas, reformuladas alternativas e melhor detalhados alguns aspectos mais relevantes, como a estrutura de gastos, por exemplo.

\section{Detalhamento do gasto dos turistas}

Outro aprimoramento relevante ocorrido nas pesquisas de Turismo Internacionais desde 2004 foi o maior detalhamento da estrutura de gastos dos turistas emissivos e receptivos. Estes dados têm sido coletados em detalhe com o objetivo de contribuir para um registro mais preciso do fluxo de divisas no país e aperfeiçoar a Construção da Balança Turismo Internacional do Brasil e da Conta Satélite do Turismo no Brasil.

\section{$\underline{\text { Perfil do fluxo emissivo de turistas internacionais }}$}

A partir de 2004 a pesquisa de perfil dos turistas brasileiros que visitam o exterior 
passa a ser regularmente desenvolvida. Este fato contribui significativamente para a comparabilidade das receitas e despesas turísticas do Brasil, levando à possibilidade de reconhecimento destas estatísticas por parte do Bacen. Além disso, passou-se a contar com informações anuais sobre o perfil deste público, fato que contribui para o desenvolvimento de ações públicas e privadas de desenvolvimento do turismo.

\section{Controle de expansão dos resultados}

Os resultados dos questionários efetivamente aplicados passaram, a partir de 2004, a contar com controles estatísticos de expansão, gerando resultados mais apurados e sem os riscos de deturpações regionais. Com o controle da expansão dos resultados, passou-se a atribuir pesos adequados aos questionários aplicados em cada um dos 22 pontos de pesquisa, melhorando significativamente as estimativas de variáveis correlacionadas com o local de pesquisa, como é o caso das cidades mais visitadas, por exemplo.

\section{Desagregação dos resultados do Turismo de Lazer}

O conceito de turismo adotado pela Embratur em consonância com as recomendações da OMT abrange diversas motivações de viagem, inclusive aquelas que não são efetuadas com fins de lazer. Contudo, o turismo de lazer, além de seu destacado reconhecimento, apresenta características distintas das viagens de negócios e visitas a amigos e parentes, por exemplo. Ressalte-se que dentre outras peculiaridades, o turismo de lazer e o de Negócios e Eventos são alvos de ações específicas da Embratur e Mtur o que passa a melhor qualificar as informações para essas duas categorias distintas:

- Turismo de Lazer;

- Turismo de Negócios, Eventos e outros tipos de não-lazer.

\section{Contagem dos fluxos turísticos internacionais}

Aperfeiçoamento e ampliação da pesquisa de contagem de turistas nas fronteiras terrestre e aérea com o intuito de complementar os dados de fluxo de entrada de visitantes não contabilizados nos registros administrativos do DPF. 


\subsection{BOLETIM DE DESEMPENHO ECONÔMICO DO TURISMO}

Parceria: FGV - Escola Brasileira de Administração Pública e de Empresas (Ebape) Apoio: Associação Brasileira da Indústria de Hotéis (Abih); Abeoc; Associação Brasileira de Restaurantes e Empresas de Entretenimento (Abrasel); Abav; Sindicato das Empresas de Turismo (Sindetur); Bito

Foi a pesquisa com a qual mais me envolvi, desde sua conceituação até a publicação dos primeiros relatórios. Eu não me conformava com a absoluta ausência de dados no país, a respeito da dimensão econômica do turismo, coletados a partir do mercado. Daí formulamos o Boletim de Conjuntura, que é uma publicação trimestral, e leva ao público o resultado de uma análise de caráter qualitativo da conjuntura econômica do turismo no Brasil.

A metodologia aplicada conta com a avaliação de três momentos: o atual, o passado recente pelas observações relativas ao trimestre anterior e a perspectiva para o trimestre seguinte em comparação ao recém concluído.

Esta pesquisa, de âmbito nacional, considera as principais variáveis econômicas do ambiente em associação com os resultados da opinião dos seguintes segmentos do turismo:

- Agências de eventos;

- Promotores de eventos;

- Meios de hospedagem;

- Operadoras de Turismo;

- Agentes de Turismo Receptivo;

- Restaurantes.

Um fator diferencial da pesquisa é a sua realização inteiramente via Internet, uma vez que os questionários são em formato digital para envio por meio de correio eletrônico para os respondentes e as respostas também são disponibilizadas de forma 
on line.

Os resultados apresentados no Boletim atuam como instrumentos de sondagem do setor com tendências e indicadores do mercado, proporcionando aos tomadores de decisão público e privado uma ferramenta que os oriente no curto e médio prazos.

Os critérios de análise da opinião dos gerentes e proprietários de negócios turísticos entrevistados englobam aspectos relativos a custos, faturamento, contratação de pessoal, oferta e demanda por seus produtos e serviços, entre outros itens que ajudam na configuração de um quadro conjuntural da economia do segmento.

A disseminação das informações é feita é feita através da área Dados e Fatos no

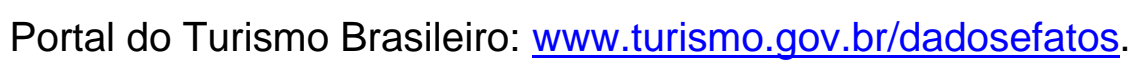

\subsection{Pesquisa Anual de Conjuntura Econômica do Turismo}

Parceria: FGV - Ebape

Apoio: Abih; Abeoc; Abrasel; Abav; Sinbdetur, Bito.

Um desdobramento do programa de trabalho anterior, a Pesquisa Anual de Conjuntura Econômica do Turismo (Pacet) identifica junto aos principais executivos de turismo a evolução e as tendências do setor no Brasil.

Com foco na visão estratégica dos empresários, a Embratur, em parceria com a FGV - Ebape ouviu 80 executivos na segunda edição da pesquisa. A representatividade da amostra confere a este estudo o status de fonte de consulta capaz de balizar os profissionais na tomada de decisão.

Os segmentos que participaram da pesquisa em 2005 foram:

- Agências de Viagens;

- Meios de hospedagem;

- Companhias aéreas;

- Operadoras de turismo;

- Operadoras de receptivo; 
-Promotores de feiras e eventos;

- Locadoras de automóveis.

A disseminação das informações é feita é feita através da área Dados e Fatos no Portal do Turismo Brasileiro: 'iwww.turismo.gov.br/dadosefatos.

\title{
5.4 Pesquisa - Meios de Hospedagem/Estrutura de Consumo e Impactos na Economia
}

\author{
Parceria: Sebrae \\ Execução: Fipe
}

Este estudo foi outra batalha para romper um paradigma vigente na estrutura da Embratur por décadas. Era hábito a contratação por parte da autarquia, ou pior, o subsídio a estados e municípios para tanto, de pesquisas que contavam quartos de hotel ou mensuravam quantos metros quadrados para eventos havia em uma ou outra cidade ou região do país. Ora, era comum que, ao concluir-se a pesquisa, verificavam a sua inutilidade, pois o número já havia se alterado. Não havia no entanto, uma só pesquisa ou estudo, sobre o impacto econômico dos diverso segmentos do turismo, na economia das regiões em que atuam. Ninguém sabia dizer qual a importância de um hotel para seus fornecedores e parceiros, assim com qual a importância de um Centro de Convenções e Feiras para a economia de uma cidade. Daí partimos para este programa: o de um estudo desenvolvido com o objetivo de analisar e detalhar as estruturas dos custos de operação e dos estoques de equipamentos e de instalações das empresas do setor de Meios de Hospedagem, como objeto do primeiro trabalho, com o intuito de avaliar e quantificar o poder de encadeamento desse setor em termos de impactos econômicos sobre os demais setores produtivos da economia, através das compras de insumos correntes e dos equipamentos e de materiais de reposição.

A análise baseou-se em dados primários levantados numa pesquisa de campo que envolveu cerca de 2.000 estabelecimentos de várias regiões do país, com pelo menos um empregado com carteira assinada, e nas informações de uma tabulação especial da Pesquisa Anual de Serviços (PAS) de 2002, do Instituto Brasileiro de 
Geografia e estatística (IBGE).

Os trabalhos de campo foram realizados nos meses de Maio a Dezembro de 2005.

A cobertura geográfica envolveu a pesquisa de estabelecimentos de hospedagem selecionados nas seguintes 15 Regiões Metropolitanas: Manaus, Belém. Fortaleza, Recife, Salvador, Belo Horizonte, Vitória, Rio de Janeiro, São Paulo, Curitiba, Florianópolis, Porto Alegre, Goiânia, Brasília e Natal.

Os resultados estão sendo divulgados através de um sumário executivo e de tabelas sínteses que apresentam os principais resultados obtidos no estudo e que podem ser consultados de forma dinâmica:

- Quantidades de Equipamentos e de Mercadorias Duráveis: Quantidades de equipamentos e de mercadorias duráveis existentes no setor de hospedagem;

- Principais Itens de Compras de Equipamentos e de Mercadorias Duráveis: Números médios dos equipamentos e das mercadorias duráveis adquiridas anualmente para reposição pelo setor de hospedagem;

- Principais Itens de Compras de Serviços de Utilidade Pública: Valores dos gastos anuais do setor de hospedagem com os serviços de água e esgoto, energia elétrica, gás, telefone, correios e Internet;

- Impactos Diretos e Indiretos do Setor de Hospedagens Sobre Emprego, Valor da Produção e Valor Adicionado: Valores dos impactos diretos e indiretos, em nível das cinco grandes regiões do país, que o conjunto das empresas do setor de hospedagem geram nos demais setores de atividade da economia brasileira, em termos de produção de bens e serviços e de geração de renda e de emprego;

- Distribuição Setorial dos Impactos Diretos e Indiretos do Setor de Hospedagens Sobre Emprego, Valor da Produção e Valor Adicionado: Valores dos impactos diretos e indiretos, em nível das cinco grandes regiões do país, que o setor de hospedagem gera em cada um dos setores de atividade da economia brasileira, em termos de produção de bens e serviços e de geração de renda e de emprego;

- Decomposição Regional dos Impactos Econômicos do Setor de Hospedagem Sobre Emprego, Valor da Produção e Valor Adicionado: Distribuição regional dos benefícios sobre a produção, a renda e o emprego, gerados pelo setor de 
hospedagem localizado em cada uma das cinco grandes regiões do país. Trata-se de indicadores que medem a capacidade desse setor em internalizar na própria região, os benefícios que a atividade gera.

O resultado deste trabalho tem um impacto brutal sobre nossa atividade econômica, pois permite finalmente que o setor se apresente, com protagonismo de seus agentes econômicos, perante outros setores e pactue uma nova forma de interlocução entre todos nas ações de promoção e desenvolvimento do negócio. Este passo, está vinculado ao conjunto da estratégia de formação de um novo modelo de gestão, na medida em que, com estes dados na mão, o setor turismo, quando passar a ser também parte integrante de uma unidade de promoção do Brasil no exterior, assumindo finalmente um papel ativo neste processo, pode construir relações de parceira econômica até aqui não tentadas, por absoluta falta de dados que nos permitissem abordar segmentos como o de combustível ou o setor de produção de alimentos ou de produtos têxteis.

\subsection{Estudo SObre Economia do TuRismo: AnÁlise das atividades Características do TURISMO - 2003}

Parceria e Execução: Instituto de Pesquisas Econômicas Aplicadas (IPEA) - IBGE

Resultado de um acordo de cooperação técnica entre IBGE, Mtur e Embratur, o estudo tem por objetivo apresentar resultados relativos à atividade de turismo, provenientes da PAS, da PAS - Suplemento Produtos e Serviços, da Pesquisa de Orçamentos Familiares (POF), e da Pesquisa Nacional por Amostra de Domicílios (PNAD), realizadas pelo IBGE, referentes ao ano de 2003.

A publicação marcou o início da divulgação dos primeiros resultados sobre a análise econômicas das atividades ligadas ao turismo a partir dos estudos de base realizados pelo IBGE e das recomendações da OMT para a questão.

Isto é, levando-se em conta que a análise econômica do turismo faz-se, 
principalmente, a partir da mensuração dos produtos (bens e serviços) que os visitantes consomem durante suas viagens e dos impostos que a oferta desses produtos exerce sobre as variáveis macroeconômicas e sua inter-relação com as demais atividades da economia.

\subsection{Indicadores Sobre Mão de Obra Formal Ocupada em Atividades Características DO TURISMO}

\section{Parceria e Execução: IPEA}

Assinatura de termo de cooperação e repasse de recursos para o IPEA para o desenvolvimento de estudos que permitam suprir a carência histórica de dados sistematizados sobre a questão de emprego no setor e conhecer a dimensão e o perfil da mão-de-obra formal ocupada em atividades características do turismo e construir indicadores conjunturais para monitorar a evolução da mão-de-obra ocupada no setor.

Entre os produtos previstos para o desenvolvimento do Projeto estão:

- Estimativas da mão de obra formal ocupada em atividades características do turismo, tendo por base os dados da Relação Anual de Informações Sociais (Rais);

- Elaboração de indicadores mensais relativos à evolução quantitativa recente da mão-de-obra formal ocupada segundo grandes setores de atividades turísticas;

- Perfil anual da mão de obra formal ocupada nas atividades de turismo.

O conjunto de pesquisas mencionadas propiciará a construção de um conjunto de indicadores sobre o mercado de trabalho no turismo que deverá ser objeto de atualização sistemática e cujos componentes principais serão divulgados nas páginas do IPEA e do Mtur/Embratur pela Internet.

As pesquisas deverão disponibilizar os seguintes indicadores, ainda em 2006:

(a) estoque mensal de empregos formais entre dezembro de 2002 e dezembro de 2004, por Atividade Característica de Turismo (ACT) (alojamento, alimentação, transporte, auxiliar de transporte, aluguel de transporte, agência de viagens, lazer e 
cultura), para o Brasil, Regiões e Estados;

(b) estimativa preliminar do estoque mensal de empregos formais para os meses seguintes a janeiro de 2005, por ACT (alojamento, alimentação, transporte, auxiliar de transporte, aluguel de transporte, agência de viagens, lazer e cultura), para o Brasil, Regiões e Estados;

(c) principais características da mão-de-obra formal ocupada por ACT (alojamento, alimentação, transporte, auxiliar de transporte, aluguel de transporte, agência de viagens, lazer e cultura), para o Brasil, Regiões e Estados.

O trabalho objetiva subsidiar a formulação e a avaliação das políticas públicas de turismo. Para tanto, buscou-se identificar, junto ao Mtur/EMBRATUR, as questões mais relevantes, no que concerne ao emprego, que se colocavam aos dirigentes desse setor. A seguir se apresenta uma relação contendo os principais temas que demandavam respostas:

a) dimensão do estoque de mão-de-obra ocupada em atividades turísticas;

b) evolução anual e mensalmente do estoque dessa mão-de-obra;

c) composição desse estoque do ponto de vista da formalização das relações de trabalho;

d) perfil e transformações que ocorrem no estoque dessa mão-de-obra (escolaridade, ocupação, idade, gênero, etc.);

e) perfil dos estabelecimentos que empregam essa mão-de-obra (atividade, dimensão, etc.);

f) contribuição dessa mão-de-obra para a formação da renda nacional.

Complementarmente, busca-se ainda também a obtenção de resultados que apresentem as seguintes características, de interesse para as políticas de turismo:

a) maior detalhamento das atividades para delimitar as principais ACTs;

b) maior desagregação geográfica possível;

c) maior especificação das características dos estabelecimentos empregadores;

d) maior especificação da mão-de-obra ocupada em seus aspectos individuais, educacionais e ocupacionais que permitam definir da forma mais detalhada o seu perfil;

e) oportunidade da informação. 
Bem como, outros atributos das informações utilizadas pelas pesquisas que propiciem:

a) a confiabilidade dos dados;

b) o nível de cobertura das fontes utilizadas;

c) seu potencial de utilização de forma coerente com o Sistema Estatístico Nacional e em especial com a Conta Satélite de Turismo (CST).

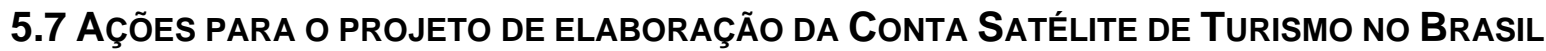

As ações até aqui (dezembro de 2006) realizadas foram:

- Levantamentos e análise de pesquisas existentes;

- Estruturação de sistema de estatística básica de turismo com o apoio do IBGE;

- Análise das pesquisas realizadas sobre o turismo no Brasil a partir das recomendações da OMT;

- Análise das pesquisas econômicas realizadas pelo IBGE para avaliar o tipo de informações disponíveis referentes à oferta e à demanda das ACTs, com vista à elaboração da CST:

. PAS - Pesquisa Anual de Serviços;

. POF - Pesquisa de Orçamento Familiar;

. PAC - Pesquisa Anual de Comércio;

. PIA - Pesquisa Industrial Anual.

- Análise das ACTs definidas pela OMT para a construção da CST e pesquisadas pela PAS: Serviço de Alojamento, Serviço de Alimentação, Serviços de Transporte de Viajantes, Agências de viagens e Organizadores de viagem, Serviços Culturais e Recreativos;

- Construção de Indicadores Macroeconômicos das ACTs, supra citadas, a partir da base de dados disponíveis na Coordenação de Contas Nacionais do IBGE;

- Avaliação do gasto turístico de residentes a partir da análise da POF 2002-2003;

- Avaliação do gasto turístico de residentes a partir da análise da POF 1996; 
- Análise do Estudo Comparativo dos gastos turísticos de residentes a partir das POF 1996 e 2002-2003;

- Diagnóstico das Monografias e das Fichas de Dados Fonte encaminhados pelos Órgãos Estaduais de Estatística e Turismo;

- Desenvolvimento de estudos de regionalização do Consumo Intermediário das ACT com o objetivo de possibilitar a construção das Tabelas de Recursos e Usos Regionais;

- Realização de dois eventos técnicos para troca de experiências com outros países, em parceria com a OMT:

- Conferência sobre Conta Satélite de Turismo - Compreender e Desenhar Estratégias - Foz do Iguaçu - Outubro de 2005;

- Realização do I Encontro Sobre Conta Satélite de Turismo dirigido a técnicos da área de planejamento responsáveis pelo cálculo das Contas Regionais - Rio de Janeiro - Julho de 2005.

\subsection{Prêmio de monografias e Mtur/Embratur/FGV de estudos de caso e REPORTAGENS DO SETOR DE TURISMO E HOTELARIA}

Promovido pelo Mtur, Embratur, em parceria com FGV, através da Ebape-FGV, tem como objetivo estimular e desenvolver o conhecimento científico relacionado com o setor de turismo e hotelaria.

Em 2005 foi lançada a terceira edição do Prêmio, e foram entregues os prêmios relativos à segunda edição, que recebeu trabalhos inscritos. Os trabalhos vencedores nas categorias pós-graduação e reportagens receberam $R \$ 5.000,00$ cada, e os de graduação $R \$ 3.000,00$. As inscrições foram finalizadas com 266 inscritos. A divulgação dos resultados e entrega dos prêmios está prevista para Agosto de 2006. 


\section{9 Área de Dados e Fatos no Portal Brasileiro de Turismo}

A Diretoria é responsável pela manutenção da área de Dados e Fatos no portal do turismo do brasileiro com a publicação de conteúdos gerenciais sobre a atividade turística, produzidos ou compilados pela Diretoria de Estudos e Pesquisas junto a diversas fontes de informações da área pública e do setor privado.

A disseminação eletrônica sobre a atividade turística no Brasil e possibilidade de acesso on line a esses conteúdos facilita a socialização das informações à sociedade civil como um todo, tornando-a ferramenta de suporte e apoio à decisão gerencial do setor público e privado.

Um outro objetivo nosso ao lançar este portal e esta área, era criar um vínculo entre o mundo real da gestão do turismo, baseado no fato de que a Embratur é indiscutivelmente um protagonista no setor, e a academia. este era o instrumento por meio do qual pretendíamos fazer chegar às escolas de todo o Brasil, um conjunto de dados que permitisse aos responsáveis pelo processo de formação dos novos profissionais, prover acesso a informação de excelente qualidade aos alunos. Infelizmente, neste ponto não fomos muito felizes nem eficazes. Em parte porque não mobilizamos suficiente energia e recursos na propagação deste instrumento, em parte porque a qualidade de muitas escolas é extremamente frágil.

A compilação de dados produzidos ou coletados por instituições constitui-se em importante ferramenta para aferição dos fluxos turísticos internacionais e domésticos, bem como do saldo produzido pela entrada e saída de divisas e são essenciais como indicadores para o acompanhamento do desempenho da atividade turística no país.

Destacam-se entre os aperfeiçoamentos implantados a mensalização do acompanhamento dos dados de colhidos, junto à Infraero e Receita Federal, feitos, anteriormente, apenas anualmente. Entre os dados compilados pela Diretoria de Estudos e Pesquisas destacam-se os relativos à: 


\section{Fluxo de entrada de estrangeiros}

Apoio: DPF

Os registros administrativos são disponibilizados pelo DPF. A Embratur vem reforçando a digitação das fichas de entrada de estrangeiros, para dar mais consistência à base de dados utilizada para a quantificação do fluxo de turistas estrangeiros recebidos pelo Brasil de estrangeiros recebidos pelo Brasil.

Em 2005, com o apoio da Embratur foi possível incrementar em 600.000 o número de fichas digitadas e transferir para o banco de dados da Embratur os registros administrativos de 1,8 milhões de fichas digitadas através de sistema especialista.

Em 2006, este mesmo apoio já está em curso a digitação de fichas referente à entrada de estrangeiros no Aeroporto de Guarulhos, maior portão de entrada do país.

Movimento de Embarque e Desembarque de Passageiros Nacional e Internacional em Aeroportos

APOIO: Infraero

Compilação de dados sobre a movimentação mensal e anual dos desembarques em vôos nacionais e internacionais, regulares e não-regulares e desenvolvimento de sistema especialista.

\section{$\underline{\text { Receita Cambial e Despesa Cambial - Banco Central }}$}

Dados: Banco Central

- Compilação de dados sobre a entrada e saída de divisas do país na Conta de viagens internacionais;

- Composição do movimento e do fluxo econômico internacional do turismo brasileiro.

É impressionante como em apenas duas linhas somos capazes de explicar e definir tecnicamente o dado mais importante para aferição de resultados de todo o processo que vimos narrando até aqui. Os dados produzidos pelo Bacen desde 1969, três anos apenas após a criação da Embratur, são o melhor e mais eficaz instrumento para avaliarmos, com apenas um número, se os esforços de planejamento, operação, investimento e análises que realizamos ao longo destes anos recentes estão na direção correta ou não. 
É este dado que, ao informar ao mercado, a cada mês, o volume de ingressos oficialmente registrado em moeda estrangeira no país por meio de turistas, possibilita avaliarmos e compararmos nossos programas de trabalho com toda a história da Embratur, praticamente desde a sua fundação. Foi a existência deste dado que me permitiu fazer em meu pronunciamento de posse na presidência da Embratur, a afirmação de que aquela seria "...uma gestão sem discursos, marcada por programas de trabalho que pudessem ser aferidos pela sociedade e pelo mercado, na medida em que buscaríamos dados gerados por instituições de credibilidade técnica indiscutível..." Foi também o fato de que este dado nunca havia sido trabalhado pela Embratur, que me intrigou profundamente, levando-me, após nossa equipe apresentar os primeiros dados de avaliação sobre o antigo setor de pesquisas de pesquisas da autarquia, a reformulá-lo completamente.

Não posso negar que me agrada muito, e me emociono sempre, quando hoje, já afastado de Brasília e de sua lides há mais de um semestre escuto pelo rádio um locutor anunciar "a Embratur informou hoje que, segundo o Banco Central, mais um recorde foi batido no ingresso de dólares no Brasil com turistas estrangeiros...".

A força deste fato e dos dados providos pelo Bacen é tão brutal que, retornando a um tema que levemente abordei ao inicio deste texto, não me surpreende que setores da mídia, porta vozes muita vezes dos setores econômicos e sociais oligárquicos e seus herdeiros, por duas vezes derrotados nas urnas, jamais o comuniquem pelo que trás de positivo ao país e ao governo que tomou a decisão política de construir um modelo de promoção que apresente tamanho volume de resultados, mas ao contrário, transformem o comunicado gerencial do Bacen, numa notícia simplória de volume de dólares gastos pelos brasileiros no exterior, esquecendo-se que também este volume, apesar do câmbio baixo, também cresce por conseqüência da melhora do ambiente econômico, do crescimento da renda disponível e das viagens envolvidas no crescimento do volume de exportações. 


\section{UM NOVO MODELO DE GESTÃO}

\subsection{Novo Modelo de Gestão e a Gestão do Conhecimento}

No modelo de aparelho de Estado desenhado neste país a partir da decisão de Dom João VI de fugir das tropas napoleônicas mudando a corte para o Rio de Janeiro, está uma prática repetida a exaustão por parte das seguidas articulações oligárquicas que foram se sucedendo a frente deste aparelho: apropriar-se deste com o objetivo de colocar seus recursos, arrecadados junto ao conjunto da sociedade, a serviço de interesses localizados destas mesmas oligarquias.

Esta prática, quando tratamos de turismo, se verifica por meio do papel desempenhado pela Embratur ao longo da maioria de seus 40 anos de existência: repassar subsídios e recursos, majoritariamente a fundo perdido, para a execução de diversos projetos, sejam de obras físicas, ações de promoção, eventos ou inserções de mídia, a estados, municípios, empresas, entidades e veículos, sem que isto se configurasse em um programa articulado de desenvolvimento para as regiões e setores beneficiados por estes recursos. Ao contrário, muitos dos recursos repassados, e os processos existentes nos arquivos da autarquia o provam, não tem qualquer relação entre si, configurando-se muitas vezes como ações isoladas e fechadas sobre si mesmas, reportando-se ao conceito inicial de apropriação do estado por grupos privados e oligárquicos.

Este modelo de Estado, posto em questão com a vitória do presidente Lula nas eleições federais de 2002 e 2006, reflete-se no turismo também pelo papel reservado a Embratur de protagonista absolutamente isolado nas ações de promoção do Brasil no exterior: o discurso dominante ao longo dos anos 1980 e 1990, repetido à exaustão sem qualquer avaliação crítica, é de que "esse é o papel do governo". Ora, nada mais ultrapassado e ineficaz do que esta consigna.

Isto já foi provado em Barcelona, em 1993 com a criação da Turisme de Barcelona, por seus resultados e pela riqueza de seus programas, assim como começa 
a ser verificado em outras regiões do mundo que traçam a mesma rota: é possível construir um outro modelo de gestão para a promoção do turismo, com participação dos setores público e privado, sob gestão compartilhada e mútua, contando com recursos de ambas as fontes, com esta mesma direção compartilhada possibilitando que o controle sobre a aplicação destes recursos se faça de forma ampla e transparente, como se espera de práticas de gestão no século XXI.

Esta nova possibilidade para o Brasil, conceito que comecei a formular e desenvolver em 1996, quando entrei em contato com o então recém nascido modelo de gestão de turismo de Barcelona, parte da premissa de que o modelo conduzido exclusivamente pelo estado chegou a seu limite de exaustão, tanto do ponto de vista financeiro, pois não há condições objetivas de ampliar eternamente o volume de investimentos públicos em promoção, quanto do ponto de vista político, pois não é correto dar seguimento a um processo no qual não há participação econômica do setor privado em programas que o beneficiam diretamente.

Por outro lado, as ações conduzidas exclusivamente pelo setor privado, na medida em que, pela própria natureza do setor, impedem os agentes econômicos, ao atuarem de forma isolada, de formularem e executarem programas que, sem perder o foco da remuneração de seus investimentos, incorpore um conjunto mais amplo de atores no processo de promoção e marketing de destino, por meio de seus produtos e serviços.

Ora, a conclusão, embora simples, de que é preciso e necessário uma ação articulada entre ambos, demanda uma reposta de equação bastante complexa: como articular interesses contraditórios entre si, concorrentes no mercado, sem tradição de articulação conjunta? Pois bem, pela redefinição do papel do aparelho de estado, atribuindo-Ihe instrumentos de gestão que permitam a inclusão efetiva e participativa do setor privado, com participação assegurada na formulação, gestão, execução e fiscalização da aplicação de recursos envolvidos em cada um dos programas a serem implementados.

Como se faz isso? Extinguindo a Embratur e substituindo-a por uma unidade de promoção e marketing, sob gestão compartilhada entre os setores público e privado, relacionando-se com o governo federal por meio de um contrato de estão, contando 
com um corpo executivo de profissionais remunerados por meio de resultados obtidos.

Este é o último dos programas que me propus a implantar na Embratur, e que minha saída um pouco antecipada acabou por obrigar-me a deixar em andamento.

No entanto, conduzido pela equipe que segue a frente da organização, o projeto segue seu andamento (no momento em que escrevo está sob análise do Ministério do Planejamento, após ter sido aprovado e apoiado pelo Mtur) rumo a um ato presidencial.

$\mathrm{Na}$ hipótese amplamente provável de sua implementação, a Embratur passará a ser uma agência de promoção, marketing e apoio à comercialização de produtos, serviços e destinos turísticos brasileiros no exterior, gerida sob um regime extremamente similar ao de uma fundação, muito parecido com de um CVB como o de São Paulo ou o do Rio de Janeiro.

Sua direção será formada por um conselho paritariamente composto entre representantes de empresas privadas e de órgãos públicos relacionados ao setor, e sua direção executiva será indicada por este conselho.

O corpo de profissionais terá composição de acordo com critérios de mercado, e haverá regras explícitas para a utilização de seus recursos em projetos, quer sejam de caráter público, quer sejam de caráter privado, quanto a percentuais máximos e mínimos de participação de recursos públicos e privados, assim como formas claras e explícitas de estão e acompanhamento de execução destes recursos.

Outra novidade é que o novo modelo permitirá de forma explícita que a agência participe de ações desenvolvidas por empresas privadas, sem necessidade de recorrer a terceiros, como entidades e outros organismos intermediários.

$\mathrm{Na}$ realidade, a extinção da Embratur, na forma como é hoje conhecida, representa o último degrau a ser vencido, do ponto de vista institucional, para dotar o Brasil do instrumental necessário para a batalha pela ampliação de sua participação no mercado internacional, para além do espaço que hoje já ocupamos, tendo praticamente triplicado o volume de ingresso de recursos em quatro anos.

O patamar atual, ainda que extremamente significativo, se comparado aos frágeis resultados das décadas de 1980 e 1990, não será superado com os atuais instrumentos de que dispomos. É fundamental romper com a lógica patrimonialista e atrasada que norteou a montagem da atual estrutura, já rompida na prática com o 
redirecionamento do papel da Embratur, e incorporar integralmente ao processo, todos os setores e agentes econômicos, que os programas lançados nestes anos recentes, trouxeram ao papel de protagonistas.

Este seria o último paradigma a ser consolidado em um novo patamar: com a sucessiva inclusão de novos destinos, entidades e agentes econômicos aos programas de promoção comercial no Brasil no exterior, é fundamental destinar papel institucional definido a estes novos protagonistas, pois na medida e quem a nova agencia terá composições paritárias de gestão, com mandatos definidos e diferenciados dos mandatos públicos, a qualidade e a perenização dos programas será vinculada exclusivamente aos resultados que estes programas apresentarem, constituindo finalmente um modelo público, porém não- estatal, de promoção comercial do turismo brasileiro.

\subsection{O Projeto do Novo Modelo de Gestão}

Reproduzo aqui um modelo de decreto, criando um novo modelo para a Embratur:

\section{DECRETO $N^{\circ}$ X.XXX, DE XX DE XXXXX DE 2007 \\ Institui a Embratur - Fundação Brasileira de Promoção do Turismo, e dá outras providências.}

O PRESIDENTE DA REPÚBLICA, no uso da atribuição que the confere o art. 84, incisos IV e VI, alínea "a", da Constituição, e tendo em vista o disposto na Medida Provisória $n^{\circ}$ XXX, de $x x$ de $x x$ de 2006,

\section{DECRETA:}

Art. 1ํ Fica instituída a Embratur - Fundação Brasileira de Promoção do Turismo, pessoa jurídica de direito privado, sem fins lucrativos e de utilidade pública, 
conforme disposto no art. $1^{\circ}$ da Medida Provisória n. XXX, de XX de Xx de 2006, com 0 objetivo de formular, implementar e executar às ações de promoção comercial dos produtos, serviços e destinos turísticos brasileiros no exterior, visando ampliar a chegada de turistas estrangeiros, assim como, o tempo de permanência e o ingresso de divisas dos mesmos no território nacional, com a finalidade de ampliar o mercado de consumo e, consequentemente, a produção e a aquisição de bens e serviços gerados no país, impactando, positivamente, o volume de emprego e renda no Brasil.

Art. $2^{\circ}$ À Embratur, na consecução dos objetivos assinalados no art. 1ำ deste Decreto, sem prejuízo de outras iniciativas consonantes com a política nacional de turismo, compete formular, implementar e executar:

I - as ações de promoção de destinos, produtos e serviços turísticos do Brasil no mercado externo;

II - as ações de marketing de destinos, produtos e serviços turísticos do Brasil no mercado externo;

III - as ações de apoio à comercialização de destinos, produtos e serviços turísticos do Brasil no mercado externo;

IV - participar, como membro e/ou mantenedora, de organizações e entidades nacionais e internacionais, públicas e privadas, de turismo;

$\mathrm{V}$ - celebrar contratos, convênios, termos de parceria, acordos e ajustes com órgãos, organizações, entidades, empresas e instituições públicas ou privadas nacionais, estrangeiras e internacionais, para a realização dos seus objetivos;

VI - propor ao Ministério do Turismo normas e medidas necessárias à execução da Política Nacional de Turismo, no que diz respeito aos seus objetivos e competências, além de executar as decisões que, para esse fim, lhe sejam recomendadas; e

VII - a interação permanente junto aos agentes econômicos ligados, direta ou indiretamente, ao turismo no mercado internacional, informando-os e orientando-os, assim como ao público potencialmente interessado, sobre os destinos, produtos e serviços turísticos brasileiros.

Parágrafo único. Para a consecução destas competências fica a Embratur autorizada a: 
a) a realizar, promover, organizar e participar de eventos, realizados no país e no exterior;

b) a realizar, promover, organizar, participar e financiar as ações de promoção, marketing e apoio à comercialização dos produtos, serviços e destinos turísticos brasileiros no exterior;

c) participar, como instituidora e/ou mantenedora, de organizações e entidades, sem fins lucrativos, que tenham, como objeto de criação, objetivo correlacionado com

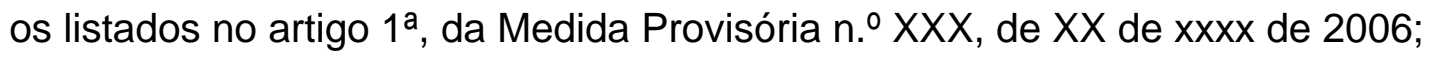

d) a instituir, dirigir e manter unidades no exterior, próprias, conveniadas ou terceirizadas;

e) instituir e manter contratos, convênios, termos de parceria, acordos e ajustes com empresas privadas, de qualquer natureza, desde que sejam observadas, no mínimo, as seguintes condições:

e.1) que seja feito um estudo de viabilidade, pelos técnicos da Embratur, que demonstre o retorno do financiamento público em, no máximo, 24 meses para o projeto de parceria;

e.2) que os recursos públicos e privados, frutos da parceria, sejam movimentados em conta-corrente específica do Banco do Brasil e administrado por um comitê bi-partite paritário designado especificamente para este fim;

e.3) que os investimentos privados, em moeda corrente, sejam de, no mínimo, 50\% (cinqüenta por cento) do total; e

e.4) sejam aprovadas por, no mínimo, dois terços da Diretoria Executiva da Embratur.

f) instituir e manter contratos, convênios, termos de parceria, acordos e ajustes com órgãos, organizações, entidades, empresas e instituições públicas ou privadas, com ou sem fins lucrativos, para distribuir e/ou divulgar a "Marca Brasil" através de licenças, cessão de direitos de uso, joint-venture, ou outros instrumentos legais;

g) instituir e manter contratos, convênios, termos de parceria, acordos e ajustes, tanto com os órgãos competentes da administração pública bem como com as entidades privadas relacionadas ao turismo, ao comércio exterior, relações exteriores, transporte aéreo, terrestre, marítimo e fluvial e de controle do ingresso e saída de 
estrangeiros do país; e

h) realizar outras ações e medidas que estejam em consonância com Medida Provisória $n .^{\circ}$ XX de Xxxxxx de 2006 e lhe sejam atribuídas pelo Ministro do Estado do Turismo.

Art. 3으 A Embratur terá a seguinte estrutura de direção:

I - Conselho Deliberativo;

II - Conselho Fiscal; e

III - Diretoria-Executiva.

Art. 4으 $O$ Conselho Deliberativo, órgão superior de direção da Embratur, é responsável pela definição das seguintes matérias, além daquelas constantes do estatuto social:

I - aprovar o estatuto social da entidade;

II - aprovar a política de atuação institucional em consonância com o contrato de gestão celebrado com o Poder Executivo, de acordo com o disposto no artigo xx da Medida Provisória $n .^{\circ}$ XXX, de Xx de Xx de 2006;

III - deliberar sobre a aprovação do planejamento estratégico da entidade;

IV - deliberar sobre a aprovação dos planos de trabalho anuais e os relatórios de acompanhamento e avaliação;

V - deliberar sobre a aprovação da proposta do orçamento-programa e o plano de aplicações apresentados pela Diretoria-Executiva;

VI - deliberar sobre a aprovação do balanço anual e a respectiva prestação de contas da Diretoria-Executiva;

VII - deliberar sobre a proposta da Diretoria-Executiva referente ao plano de gestão de pessoal e ao plano de cargos, salários e benefícios, assim como sobre o quadro de pessoal da entidade; 
VIII - analisar e deliberar sobre a aprovação do manual de licitações e de contratos, convênios, termos de parcerias, acordos e ajustes apresentado pela Diretoria-Executiva, e suas posteriores alterações, observado o disposto no artigo $x x$ da Medida Provisória $n .{ }^{\circ}$ XXX, de xx de XX de XXXX; e

IX - fixar o valor da remuneração dos membros da Diretoria-Executiva, observado o disposto no artigo xx da Medida Provisória $n .{ }^{\circ}$ XXX, de xx de xx de 2006.

$\S 1^{\circ}$ O Conselho Deliberativo será presidido pelo Ministro de Estado do Turismo.

I - O Ministro de Estado do Turismo poderá, se assim desejar, designar representante para substituí-lo na Presidência do Conselho Deliberativo.

II - O Conselho Deliberativo será composto, ainda, por representantes do Ministério das Relações Exteriores, da Secretaria de Comunicação da Presidência da República, Banco do Brasil S.A., Agência de Promoção de Exportações do Brasil Apex-Brasil, Empresa Brasileira de Infra-estrutura Aeroportuária - Infraero, do Petróleo Brasileiro S.A. - Petrobras e seis representantes de entidades do setor privado do turismo no país que tenham assento no Conselho Nacional do Turismo - CNTur e respectivos suplentes, escolhidos na forma estabelecida em regulamento, com mandato de dois anos.

$\S 2$ ○ O Substituto do Presidente do Conselho Deliberativo será eleito dentre os conselheiros, por maioria simples.

§ 3으 O Presidente e os demais membros do CD e os membros do CF não serão remunerados sendo o seu trabalho considerado de relevante interesse público.

§ 4으 $\mathrm{O}$ membro do Conselho Deliberativo será destituído do cargo em virtude de renúncia ou por decisão de dois terços dos membros do Conselho, nas hipóteses de condenação em processo administrativo disciplinar, quando seu procedimento for declarado incompatível com o decoro administrativo, quando omitir-se em relação aos deveres que o cargo the impuser em norma estatutária e quando for condenado em processo com decisão judicial transitada em julgado. 
Art. 5으 O Conselho Fiscal, órgão responsável pela fiscalização e controle interno da Embratur, é responsável pelas seguintes matérias, além daquelas constantes do estatuto social:

I - fiscalizar a gestão administrativa, orçamentária, contábil e patrimonial da entidade, compreendendo os atos do Conselho Deliberativo e da Diretoria-Executiva, observado o disposto no contrato de gestão; e

II - deliberar sobre a aprovação do balanço anual e a respectiva prestação de contas da Diretoria-Executiva, depois da sua aprovação pelo Conselho Deliberativo.

$\S 1 \stackrel{\underline{\underline{O}}}{\mathrm{O}}$ Conselho Fiscal será composto por um representante do Mtur, um representante da Controladoria Geral da Presidência da República e um representante do CNTur, e seus respectivos suplentes, todos com mandato de dois anos.

$\S 2 \stackrel{\underline{0}}{\mathrm{O}}$ Presidente do Conselho Fiscal será eleito dentre os conselheiros, por maioria simples.

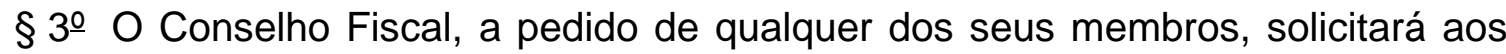
órgãos da Administração da Embratur informações ou esclarecimentos, desde que relativos à sua função fiscalizadora, bem como a elaboração de demonstrações financeiras ou contábeis específicas.

§ 4ํㅡ Será destituído do cargo o membro do Conselho Fiscal que incorrer em

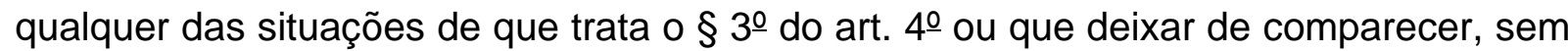
justificativa, a três reuniões ordinárias consecutivas ou a seis reuniões ordinárias alternadas durante o prazo do mandato.

Art. 6으 A Diretoria-Executiva é o órgão responsável pela gestão da Embratur, em conformidade com a política aprovada pelo Conselho Deliberativo, competindo-Ihe:

I - cumprir e fazer cumprir o estatuto e as diretrizes da entidade;

II - cumprir e fazer cumprir o contrato de gestão celebrado com o Poder Executivo;

III - elaborar e executar o planejamento estratégico da entidade; 
IV - elaborar e executar os planos de trabalho, bem como produzir os relatórios de acompanhamento e avaliação;

V - elaborar e executar a proposta do orçamento-programa;

VI - elaborar o balanço anual;

VII - prestar contas quanto à execução do contrato de gestão;

VIII - elaborar plano de gestão de pessoal e plano de cargos, salários e benefícios, assim como o quadro de pessoal da entidade;

IX - elaborar proposta de manual de licitações, bem como suas posteriores alterações, observado o disposto no artigo xx da Medida Provisória $n .{ }^{\circ}$ XXX, de $x x$ de $x X$ de XXXX; e

$\mathrm{X}$ - exercer as demais atribuições que o estatuto definir.

$\S 1 \stackrel{0}{ }$ A Diretoria-Executiva é composta por um Presidente, indicado pelo Presidente da República, e por cinco Diretores, indicados pelo Ministro do Estado do Turismo, aprovados pelo Conselho Deliberativo e nomeados pelo Presidente da Embratur, demissíveis "ad nutum”, todos para um período de quatro anos, podendo ser reconduzidos uma única vez.

$\S 2$ 을 As atribuições e os requisitos técnico-profissionais mínimos para os membros da Diretoria-Executiva serão definidos no estatuto social da entidade.

Art. 7으 Compete ao Ministro de Estado do Turismo supervisionar a gestão da Embratur.

$\S 1$ 응 $O$ Ministério do Turismo, em conjunto com a Embratur, definirá os termos do contrato de gestão, observado o disposto na Medida Provisória . $^{\circ} \mathrm{XXX}$, de $\mathrm{xX}$ de $\mathrm{xX}$ de $\mathrm{XXXX}$.

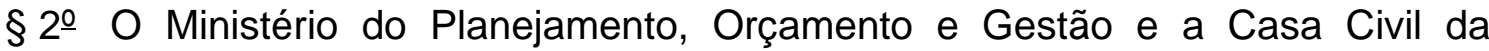
Presidência da República deverão analisar previamente o contrato de gestão, sendo o pronunciamento favorável desses órgãos pré-requisito para a sua assinatura. 
§ 3 o $O$ contrato de gestão será publicado no Diário Oficial da União, pelo Ministério do Turismo, por ocasião de sua celebração, revisão ou renovação, em até quinze dias, contados de sua assinatura.

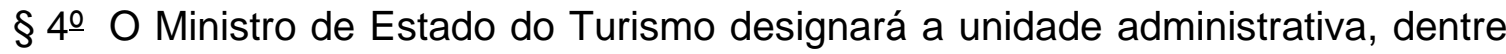
as já existentes na estrutura do Ministério, incumbida do acompanhamento do contrato de gestão.

$\S 5$ o $O$ contrato de gestão estipulará as metas, objetivos, prazos e responsabilidades para sua execução, bem assim especificará os critérios objetivos para avaliação da aplicação dos recursos repassados à Embratur e os seguintes elementos mínimos:

I - objetivos e metas da entidade, com seus respectivos planos de ação anuais, prazos de consecução e indicadores de desempenho;

II - demonstrativo de compatibilidade dos planos de ação anuais com o orçamentoprograma e com o cronograma de desembolso, por fonte;

III - responsabilidades dos signatários em relação ao atingimento dos objetivos e metas definidos, inclusive no provimento de meios necessários à consecução dos resultados propostos;

IV - penalidades aplicáveis à entidade e aos seus dirigentes, proporcionais ao grau do descumprimento dos objetivos e metas contratados, bem assim eventuais faltas cometidas;

V - condições para sua revisão, renovação e rescisão; e vigência.

$\S 6$ o $O$ contrato de gestão terá a duração mínima de dois anos, podendo ser modificado na forma disposta no artigo $x x$ da Medida Provisória $n .^{\circ} X X X$, de $x x$ de $x x$ de $X X X X$, bem como ser renovado, desde que submetido à análise e à aprovação referida no $\S 2 \stackrel{\circ}{\varrho}$ deste artigo. 
$\S 7$ 으 A Diretoria-Executiva submeterá anualmente para análise e deliberação do Mtur o orçamento-programa da Embratur para execução das atividades previstas no contrato de gestão, observado o disposto no inciso IV do caput do art. 4으․

$\S 8$ o Por ocasião do termo final do contrato de gestão, será realizada pelo Ministério do Tursimo avaliação conclusiva sobre os resultados alcançados.

Art. 8으 A Embratur apresentará, anualmente, ao Ministério do Turismo, até 31 de janeiro, relatório circunstanciado sobre a execução do contrato de gestão no exercício anterior, contendo, no mínimo, as seguintes informações:

I - prestação de contas dos recursos aplicados no exercício;

II - a avaliação geral do desempenho da entidade em relação aos indicadores estabelecidos no contrato de gestão; e

III - análises gerenciais cabíveis.

Parágrafo único. Até 28 de fevereiro de cada exercício, o Ministério do Turismo analisará o relatório de que trata este artigo e emitirá parecer sobre o cumprimento do contrato de gestão pela Embratur.

Art. 9으 A Diretoria-Executiva remeterá ao Tribunal de Contas da União, até 31 de março do ano seguinte ao término do exercício financeiro, a prestação de contas da gestão anual aprovada pelo Conselho Deliberativo, acompanhada de manifestação do Conselho Fiscal, sem prejuízo do disposto no artigo $x x$ da Medida Provisória $n .{ }^{\circ} X X X$, de $x X$ de $x x$ de $X X X X$.

Art. 10. A Embratur e o Ministério do Turismo constituirão comissão de trabalho específica para adotar os procedimentos necessários à efetivação das medidas de que tratam os artigo $\mathrm{xx}$ da Medida Provisória $\mathrm{n} .^{\circ} \mathrm{XXX}$, de $\mathrm{xX}$ de $\mathrm{xX}$ de $\mathrm{XXXX}$.

Art. 11. O Ministério do Turismo por meio dos instrumentos jurídicos aplicáveis, transferirá à Embratur, de comum acordo com a esta, os direitos e deveres relativos aos contratos, convênios, termos de parcerias, acordos e ajustes que estejam em vigor e que sejam necessários para a atuação da Fundação e tratam dos projetos e programas 
em execução pelo Instituto Brasileiro de Turismo, bem assim os recursos reservados para esse fim.

Parágrafo único: O disposto no caput deste artigo não se aplica a recursos recebidos pelo Ministério do Turismo após a edição da Medida Provisória $n .{ }^{\circ} \mathrm{XXX}$, de $x X$ de $X X$ de $X X X X$.

Art. 12. O Ministério do Turismo poderá dar prosseguimento aos contratos, convênios, acordos e demais instrumentos que tratam dos projetos e programas em execução pelo Instituto Brasileiro de Turismo, bem como as respectivas despesas relativas ao custeio de pessoal e manutenção, até o registro dos atos constitutivos da Embratur, mediante acerto dos valores que houver dispendido desde a edição da Medida Provisória $n . \stackrel{0}{X X X}$, de $\mathrm{xX}$ de $\mathrm{xX}$ de $\mathrm{XXXX}$, quando transferir os direitos $\mathrm{e}$ deveres previstos no art. 11 deste Decreto.

Art. 13. Os atos que originaram a criação dos Escritórios Brasileiros de Turismo de Londres, Paris, Novo lorque, Lisboa, Frankfurt, América do Sul, Milão e Madrid, estão convalidados com base no artigo $\mathrm{x}^{\circ}$, da Medida Provisória n. ${ }^{\circ} \mathrm{XXX}$ de $\mathrm{xX}$ de $\mathrm{XXXX}$.

Art. 14. Fica revogado o .

Art. 15. Este Decreto entra em vigor na data de sua publicação.

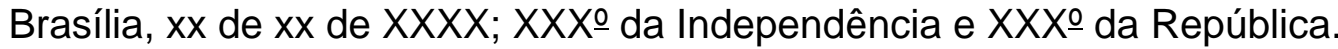
LUIZ INÁCIO LULA DA SILVA Walfrido dos Mares Guia Neto 


\section{CONCLUSÃO: EQUIPE, CENÁRIO INSTITUCIONAL E PROJETO DE FUTURO}

\subsection{A QUALIDADE DA EQUIPE, A EMOÇÃO PRESENTE E MUITA CLAREZA POLÍTICA}

O que ocorreu com o turismo receptivo internacional no Brasil com a reestruturação completa do foco de atuação, do processo de formulação, assim como da forma de atuação com a Embratur, na esteira da criação do Mtur, abre uma perspectiva interessante para reflexão.

Ao longo dos anos 1960 e 1970, a Embratur (então única unidade federal atuando no setor turismo) está ligada à infra-estrutura e à normalização. Ao longo dos anos 1980, segue com as mesmas atribuições, somadas a um conjunto de iniciativas interessantes, embora, de acordo com os resultados obtidos, pouco eficazes, de promoção do país no exterior. A década de 1990 assiste a Embratur agregar mais um dado a sua história, com os programas que obtém alguma consistência em desenvolvimento regional e local em turismo, seguindo, no entanto, sem avançar de forma consistente no mercado internacional.

Quando se inicia o século XXI, era patente que o país avançava em infraestrutura pública (especialmente com os novos aeroportos) e privada (hotelaria, gastronomia), avançava também em recursos humanos (notem quantos brasileiros assumem o comando de operações em empresas estrangeiras) e serviços (telecomunicações e internet). Por outro lado, não se organizava para contar isso aos consumidores que podiam, por meio desta infra-estrutura renovada, somar à economia nacional um dado novo: o ingresso de um volume considerável de moeda estrangeira, em regiões que não se beneficiaram de movimentos anteriores de crescimento econômico. Qual seja, o turista estrangeiro.

A criação do Mtur em janeiro de 2003 pelo Presidente Luis Inácio Lula da Silva, com a conseqüente redefinição de atribuições por toda a sua estrutura, libera uma energia jamais utilizada na história econômica do país - a Embratur passa a dedicar-se exclusivamente a promoção, marketing e apoio à comercialização de produtos, serviços 
e destinos turísticos brasileiros no exterior.

Procurei descrever, nas páginas anteriores, o cuidado que tivemos enquanto equipe para com cada programa de trabalho. Afinal, em se tratando de programas inéditos, com um grau de inovação que rompia com práticas de décadas, e com uma rapidez de execução que tornava arcaicas as estruturas e práticas de gestão até então vivenciadas pela sociedade e pelo mercado em relação ao turismo, não podíamos descuidar de nenhum detalhe.

Hoje, alegro-me acompanhando a mídia especializada e até mesmo a mídia geral divulgando e comentando cada anúncio mensal de ingresso de divisas que faz o Bacen. Emociono-me quando alguém comenta que esteve em um evento na Europa e encontrou com o responsável pelo EBT conduzindo alguns programas de trabalho. Recentemente estive em Amsterdã para uma reunião profissional e, caminhando ao final da tarde, observei feliz a vitrine de quatro ou cinco agências de viagem anunciando variados destinos brasileiros, em uma delas, não resisti a chamar o Brasil por celular, quando vi a Marca Brasil impressa nos folhetos. Do outro lado da linha, a presidente da Embratur (escrevo esta conclusão em março de 2007, pouco mais de seis meses após deixar Brasília), reunida naquele exato momento, por coincidência, com alguns diretores da casa e com a CTI Nordeste escutavam meu relato, diretamente do inverno holandês, listando, qual criança, os destinos anunciados, como se fossem, cada um deles, um presente do Natal que estava por chegar.

Esta descrição final revela o grande segredo, a resposta à questão que me foi formulada ao longo destes últimos anos incessantemente, muitas vezes em off (como a imprensa denomina uma pergunta cuja resposta não será publicada, servindo para melhorar a compreensão do tema por parte do jornalista que a formula): o que realmente fez a diferença? Qual foi objetivamente o fator gerador dos resultados apresentados ao Brasil recentemente?

Bem, eu lhes digo: há três fatores combinados, que respondem a estas dúvidas. Em primeiro lugar, o grande segredo, o pulo do gato: a qualidade da equipe da Embratur. O cuidado que tivemos ao escolher, o Ministro Mares Guia e eu, cada diretor e a partir daí, com a participação destes, cada gerente da Embratur, foi extremamente rigoroso. Ato contínuo, o processo se repetiu a cada técnico que foi incorporado à 
equipe por meio de um cuidadoso programa de integração.

O que hoje o turismo brasileiro tem de mais importante para seguir disputando o mercado internacional é exatamente esta equipe da Embratur, já com novos integrantes, incorporados sob os mesmos critérios. A solidez técnica, gerencial e a clareza de conceitos que se reúnem por meio desta equipe são incomparáveis, com resultados comprovados e a capacidade para superar desafios largamente testada ao longo do período recente.

Mais ainda, a unidade construída na equipe e a profunda relação de solidariedade existente entre todos nós geraram a estória da Aldeia Gaulesa, que eu homenageio com uma dedicatória na abertura deste trabalho: dizíamos entre nós que aqueles que olhavam do lado de fora, viam na Embratur uma gente muito diversificada - brancos e negros; homens e mulheres; católicos, judeus e evangélicos; magros e gordos; heterossexuais e homossexuais; enfim, gente de tudo o que é tipo - mas se alguém se atrevesse a tocar em qualquer um de nós, tal qual a aldeia gaulesa das histórias de resistência contra a invasão romana, a reação era avassaladora.

Este clima contagiante de mobilização e desafio leva ao segundo fator - a emoção e a emotividade, gerada a partir da construção desta equipe. Ficamos todos conhecidos, eu especialmente, pelo número de vezes que choramos em público a cada vitória conquistada: no lançamento da Marca Brasil e do Plano Aquarela; na inauguração de alguns dos EBTs; quando passamos a figurar entre os Top 10 no ranking ICCA, ou quando finalmente superamos, pela primeira vez em toda a história da economia brasileira, os US\$ 3 bilhões em ingresso anual de divisas com turismo estrangeiro.

A paixão e a emoção, portanto, dirigidas com entusiasmo rumo a um conjunto claro de objetivos, elevou a um estágio superior o compromisso profissional de cada de um de nós. Não se tratava apenas de acordar pela manhã e tocar a vida - era um constante ritmo de adrenalina elevada, marcado por desafios e adversários a enfrentar, notadamente o despreparo da estrutura institucional do próprio turismo, acostumada ao ritmo menos focado em resultados dos anos 1990, aliada ao choque causado na burocracia federal pelo já mencionado ineditismo dos programas lançados.

Aqui eu gostaria de fazer menção a um outro fator, que ao longo deste trabalho, 
marcado pela descrição de programa e projetos, acabei por não mencionar: a importância das áreas meio da Embratur neste processo. Com a recomposição praticamente integral da equipe, a Embratur passa a dispor de algumas novidades que aparecem pouco para o público externo, mas são fundamentais para o cumprimento dos compromissos que assumimos por todo o país e ao redor do mundo:

- passamos a dispor de uma unidade de gestão financeira competente e capaz de planejar o desembolso de recursos ao longo de todo o ano. Parece simples, mas imaginem que a Embratur nunca tinha planejado o desembolso de seus recursos. Para ter-se uma idéia, passamos a pagar nossos conveniados, eventos, estados ou prestadores de serviços, com antecipação;

- passamos a dispor de uma unidade de gestão de convênios, cuja meta era manter a legalidade dos termos pactuados entre nós e terceiros, mas também regularizar mais de trezentos processos que encontramos em aberto, e que nos cabia regularizar, na medida em que muitos dos envolvidos, não teriam mais a possibilidade de participar de programas da Embratur, caso não tivessem sua situação regularizada perante a união;

- passamos a dispor de uma unidade jurídica empenhada em construir a solução legal para nossas decisões gerenciais, alterando completamente a prática tradicional destas unidades. Esta unidade inclusive foi decisiva em vários dos momentos em que precisei de apoio para assumir os riscos do ineditismo e do vanguardismo representado por programas como os EBTs, a Caravana Brasil e o benchmarking, por exemplo;

- passamos finalmente a dispor, e novamente pela primeira vez na Embratur, de uma unidade de Recursos Humanos. Esta unidade, passando a tratar gente e suas questões, separadamente de materiais e processos, é a síntese de todo este programa de trabalho. Quanto lançamos os programas de seminários periódicos, de treinamento constante, de comemorações coletivas de aniversários, datas festivas, resultados obtidos e finalmente, quando iniciamos um processo de ação para rever os salários e remunerações de toda a estrutura do quadro permanente, lá estava o dedo e a capacidade de trabalho desta unidade;

- passamos finalmente, a contar com uma equipe de profissionais de $\mathrm{TI}$, capaz de 
construir em breve praticamente uma Embratur virtual, na qual o fato de boa parte de nossos profissionais passarem grande parte de seu tempo fora do país, em eventos e atividades como as que descrevi ao longo deste texto, não interferem em mais nenhum processo incisório, pois toda a gestão estará disponível em meio eletrônico.

É também mérito desta equipe de administração e finanças a reforma das instalações da Embratur, os leões de compra on line e algo que de tão simples não precisaria sequer de menção, mas por ter representado uma mudança tão grande de prática em nossa história vale registrar: passamos a entregar, em qualquer lugar do mundo, a tempo e a hora adequados, toneladas de materiais de promoção em sua mais variadas formas. Qual seja, sem este conteúdo de provimento de apoio, nenhum dos programas citados até aqui, teria sequer sido iniciado.

Retornando ao histórico que estava descrevendo, mencionava algumas disputas nas quais nos envolvemos, notadamente com os estamentos da burocracia federal. Para descrever a analisar estas disputas, tenho que introduzir o terceiro fator: a clareza das opções políticas que fizemos ao longo do tempo, assim como a correção das visões políticas que nos orientaram: muitos analistas passaram os últimos quatro anos dizendo que "finalmente a Embratur, com uma diretoria que não foi politicamente montada, como as que a antecederam, agora constrói resultados etc. etc.”. Vamos analisar esta frase com cuidado.

Em primeiro lugar, nossa diretoria foi composta a partir de uma clara decisão política: o Presidente da República e o Ministro do Turismo tomaram a decisão de profissionalizar a Embratur. Não há na história recente do turismo decisão política mais séria do que esta. A confusão dos nossos analistas, notadamente a mídia do setor, se dá por considerarem como decisão política, a montagem de diretorias como historicamente ocorreu na Embratur - a partir de relações de parentesco ou subordinação a detentores de mandato executivo ou legislativo, ainda que resultando em diretores com pouca ou nenhuma intimidade com o turismo.

Ora, isto que ocorria até o período anterior ao nosso era uma decisão política errada, e os resultados estão aí para provar. O que ocorreu conosco não foi uma decisão não-política, ao contrário, foi o mais radical gesto político dos 40 anos de história da Embratur - decidir, e depois bancar a decisão, compor uma diretoria, e na 
seqüência uma equipe gerencial, a partir de profissionais com história no mercado turístico, em seus vários segmentos.

Em segundo lugar, também não é de todo correto afirmar que nossa equipe não tinha posições políticas. O que não tínhamos era uma uniformidade partidária. Alguns de nós não éramos filiados a partido nenhum, tendo tido no entanto militância, ao longo de boa parte da vida, em partidos que, com o final da ditadura militar, foram diminuindo até a extinção, como o PCB, do qual fui membro.

Outros tinham filiação partidária. O que nunca fizemos foi perguntar antes, ou usar como critério para recrutamento, estas posições. Sempre tivemos posições políticas na equipe da Embratur, e sempre tivemos instrumentos e espaços para fazer debates e análises. A pluralidade marcou nossa equipe, portanto, sendo explicitada em vários níveis:

- reuniões semanais de diretoria;

- reuniões mensais de gerentes;

- seminários semestrais de planejamento; e

- reuniões temáticas que organizávamos sempre que julgávamos que algum tema novo estava por envolvermos.

Estes momentos de debate e reflexão foram decisivos para construir nossa unidade do ponto de vista conceitual e ideológico, a partir de pontos de vista plurais e diversos sobre o cenário político e econômico que o País vivia a cada passo, sobre o ambiente do mercado turístico, sobre como nos posicionaríamos a cada fato que ocorria e, finalmente, sobre como estabeleceríamos as relações com cada agente institucional e econômico do mercado turístico - as entidades, a mídia, as secretarias de estado e municípios, e as empresas de vários segmentos.

$E$, finalmente, foram decisões absolutamente políticas, pois decidiram para onde e por meio de quem seriam investidos recursos públicos, as que determinaram fatos como a inclusão do setor de eventos na agenda federal, a inclusão do setor de viagens corporativas, ou ainda a inclusão do setor de feiras, para ficar em apenas três exemplos de mudanças conceituais profundas em relação aos anos 1980 e 1990. 


\subsection{Cenário Institucional}

Um outro dado que merece ser retomado nesta conclusão é uma avaliação sobre o cenário institucional do turismo brasileiro. Com a recriação do Conselho Nacional de Turismo, praticamente todas as organizações do setor foram incorporadas ao processo de formulação e debate a respeito das políticas públicas para o turismo brasileiro, assim como ganharam um fórum para expressar suas questões ao conjunto do setor e ao governo.

No entanto, isso ocorre ainda com boa parte destas entidades dirigidas pelas mesmas concepções que lidaram com a estrutura federal nos anos 1990, tendo vivenciado, portanto, uma era sem projetos ativos, metas ou planos estruturados para propor-Ihes um rumo. Isto faz com que estas organizações, acostumadas a um papel passivo da Embratur ao longo de um enorme período de tempo - aquilo que ficou conhecido como o "balcãozinho de projetos" - tenham adquirido a prática de apresentar seguidas reivindicações e projetos ao governo federal, sem qualquer relação entre eles, ou entre estes e um programa de trabalho, a fim de obter recursos para atender a demandas setoriais e corporativas.

Conferindo apenas os convênios que estavam em aberto quando chegamos a Brasília - isto é, aproximadamente 320, sem prestação de contas dos recursos repassados - notamos que universidades, entidades representativas, cidades, estados e, finalmente, dezenas de veículos de comunicação haviam recebido recursos federais para implantar projetos que não dialogavam entre si, não tinham identidade na linguagem gráfica ou conceitual, não tinham objetivos complementares e mais, algumas vezes se sobrepunham, notadamente os eventos organizados no exterior por secretarias de estado.

Não se deve, no entanto, quero deixar isso claro, inferir a partir destes fatos que houvesse algo condenável ou incorreto ocorrendo. O que estamos descrevendo é uma típica situação de ausência de planejamento, rumo político, plano estratégico e prática gerencial. Ora, na ausência destes elementos, ausência esta comprovada tecnicamente pelos programas implantados e resultados obtidos a partir da reestruturação da 
Embratur em 2003, cada organização, em cada estado ou município da união, ficava liberada para agir como melhor the parecia na defesa de seus interesses.

Este cenário era a prática vigente quando começamos, e esta, creio, segue sendo a grande dificuldade da estrutura instrucional do turismo para mover-se rumo a um novo patamar econômico neste país.

O que observamos em Brasília ao longo deste período foi uma contínua, porém muito lenta alteração positiva deste cenário, considerando que a dependência absoluta de recursos federais segue sendo uma realidade para a maioria dos setores. As entidades mal se sustentam com recursos de seus membros, o setor público estadual e municipal em turismo, segue com pequenos percentuais dos respectivos orçamentos, os veículos de comunicação seguem tendo dificuldades para manter-se apenas com venda de publicidade ao mercado e inúmeros profissionais tornam-se consultores a cada semestre, formulando projetos via fundações e universidades, sempre tendo como fonte majoritária de recursos, quando não única, o orçamento da União.

O que este cenário gera, e é aí que o problema reside, é uma relação de dependência e freqüentemente de subordinação entre a organização institucional do turismo e o governo federal, o mesmo se reproduzindo em menor escala por estados e municípios, lançando a todos num cenário conjuntural de absoluta ausência de crítica ou análise técnica de confrontação de resultados econômicos de programas.

Daí a propalada cordialidade vigente no setor,com inúmeras associações de amizade reproduzindo-se ao redor do país, que marcaram os anos 1980 e 1990, embora hoje com espaço severamente reduzido, ainda encontrar repercussão.

É interessante destacar que, quanto maior o espaço obtido pelo discurso das associações não-produtivas em certas regiões ou segmentos, maior o descolamento destas mesmas regiões ou segmentos, dos rumos atuais da economia e do turismo rumo à profissionalização, à globalização, à inclusão das grandes corporações ao nosso cenário cotidiano e, principalmente, rumo a um conjunto de programas de trabalho que apresente resultados mensuráveis ao país, substituindo de vez a geração que fez do discurso amistoso um instrumento de trabalho.

O que a já mencionada recriação do Conselho Nacional de Turismo possibilitou foi a liberação de um conjunto de energias e concepções, até então sem espaço para 
repercussão junto aos formadores de opinião, que acabam por sustentar algumas atitudes e decisões muito interessantes para a mudança de práticas que, repito, ainda está em curso, fatos marcantes são:

- o envolvimento de todos na elaboração do primeiro e depois, do segundo, PNT;

- o estabelecimento de cotas e regras para repasse de recursos a estados e municípios, via Conselhos Estaduais de Turismo; e

- as alianças que, por decisão política nossa, fizemos com entidades diferentes a cada programa lançado.

Estes dados geraram conseqüências tais como a substituição de várias lideranças em organizações tradicionais por executivos habituados a lidar com resultados e busca de auto-suficiência, ou ainda a contratação de executivos em organizações antes conduzidas nas horas vagas por seus dirigentes. Este último dado agregou um valor inestimável ao processo gerencial do setor, na medida em que, a partir deste ponto, inicia-se um novo patamar de debates entre a sociedade e o governo, no qual um conjunto de profissionais começa a articular a defesa de interesses corporativos com a compreensão da complexidade dos movimentos econômicos dos anos que vivemos.

Este é o desafio para o século XXI: manter os maiores valores identificados pelas pesquisas do Plano Aquarela junto aos clientes estrangeiros a respeito do Brasil - a receptividade, a cordialidade, a hospitalidade e a diversidade cultural - como item fundamental de nossa ação de promoção comercial e marketing institucional, sem deixar que estes conceitos voltem a distorcer as necessárias relações profissionais independentes e críticas que devemos construir entre todos os agentes econômicos e institucionais do setor, rumo a consolidação de uma atividade sólida, auto suficiente e rentável para o Brasil.

Com o movimento que estamos percebendo na sociedade - movimento desigual, vale a pena sempre registrar, pois não é uniforme em todo o país nem em todos os setores, mas que anda no sentido da renovação e do avanço técnico - podemos começar a desenhar o fator que pode, aí sim, consolidar a nova etapa ora em gestação na economia do turismo brasileiro: a redefinição dos papéis de cada um dos agentes que atuam no sistema. Esta redefinição deve abranger tanto o papel institucional como 
o econômico e o político de cada um. Estou convencido, como demonstrei no capítulo anterior a este, que a redefinição se dá com a implantação de um novo modelo de gestão para a promoção comercial do turismo brasileiro.

\subsection{Projeto de Futuro}

Quando, em 1996, concluí meu programa de trabalho em Barcelona e iniciei meu regresso ao Brasil, trazia na bagagem algumas certezas e várias pretensões: eu estava convencido de que o modelo de gestão implantado na capital catalã em 1993 com a criação da Turisme de Barcelona era uma solução extremamente eficaz. Estava seguro também de que poderia apresentar um projeto semelhante para enfrentar problemas históricos do turismo brasileiro. Quanto às pretensões, achava que teria capacidade de reproduzir este modelo na cidade de Santos ainda na mesma década de 1990, e mais, imaginava que era tão claro que não haveria resistências.

Bem, o tempo mostrou que o mundo nem sempre concorda conosco, e que quando se trata de economia, portanto dos resultados que as pessoas e organizações vão aferir, nem sempre o que parece claro é o que será feito.

Passados quase onze anos de meu retorno da Espanha no entanto, as opções políticas que fiz ao longo de minha vida, somadas aos resultados de meu exercício profissional ao longo destes mesmos anos, me levaram a presidência da Embratur. Esta posição permitiu-me exercitar todas as proposições que trazia desde então, em termos de concepções de planejamento e gestão, promoção e marketing, e articulação institucional e comercial.

Finalmente, permitiu-me apresentar a todos aqueles que têm poder de decisão neste país, na condição de protagonista - agora eu - um programa de trabalho que credenciou uma equipe a formular o projeto mais ambicioso que o Brasil já viu de gestão federal para o turismo: a construção de um modelo público não-estatal de promoção internacional, cujo financiamento provirá de outras fontes que não apenas o orçamento da união. 
$\mathrm{Na}$ realidade, com este programa temos por objetivo responsabilizar um conjunto amplo de agentes econômicos e institucionais pelo processo de obtenção de resultados para o turismo brasileiro.

Lembro-me de uma entrevista que concedi ao canal Globonews, em 2005, assim que se constatou, novamente com dados do Bacen, corroborados por um documento da OMT, que o turismo internacional no Brasil tinha crescido em 2004, acima da média do mercado mundial (fato que voltaria a se repetir em 2005 e 2006). Naquela entrevista, pela primeira eu informava ao país que havíamos finalmente iniciado uma disputa no mercado internacional, pois aquele dado significava que, havíamos, até que enfim, depois de décadas, crescido sobre clientes de outros destinos, avançado sobre segmentos de mercado que anteriormente não consideravam a uma viagem ao Brasil.

Utilizei-me de uma figura de linguagem para explicar de forma clara aos telespectadores o que significava aquele resultado. Eu disse: "agora é que começamos a jogar na primeira divisão. Agora portanto é que vem cotovelada, chute na canela e botinada". O que eu procurava dizer é que, ao momento em iniciamos uma ação que impacta os resultados de outros países, nossos concorrentes, corresponderá uma ação em sentido contrário, o que já se verifica por parte de México e Argentina - trocando suas marcas e estratégias - e se verificará em breve por parte de destinos caribenhos.

Estou convencido de que para, continuarmos nossa rota na primeira divisão, rumo a resultados mais expressivos e números ainda maiores que os já obtidos, é fundamental concluirmos o processo de mudança do modelo de gestão da Embratur. É o último item do programa elaborado ao longo de todo o ano de 2002, programa este que foi praticamente todo incorporado no PNT. Sendo que este ponto, por sua delicadeza e complexidade, resolvemos deixar de inserir, para voltar a ele quando a consistência de nossos resultados nos autorizasse.

É pois chegada a hora, estão dadas todas as condições objetivas e subjetivas, tanto institucionais como econômicas, para que esta mudança se realize, inserindo de forma definitiva o Brasil como player competitivo na disputa internacional do mercado turístico. 


\section{REFERÊNCIAS BIBLIOGRÁFICAS}

BENI, Mário Carlos. Análise Estrutural do Turismo. São Paulo: Senac São Paulo, 1998.

CHIAS, Josep. El negocio de la felicidad. Madrid: FT Prentice Hall, 2005.

EMBRATUR. Caracterização e Dimensionamento do Turismo Internacional no Brasil 2004- 2005: metodologia e resultados preliminares do receptivo. Brasília, Julho/2006.

INTERNATIONAL CONGRESS \& CONVENTION ASSOCIATION. Statistics Report: International Association Meetings Market 1995-2004. Amsterdam, Outubro/2005.

INTERNATIONAL CONGRESS \& CONVENTION ASSOCIATION. Statistics Report: International Association Meetings Market 1996-2005. Amsterdam, Junho/2006.

MTUR - CONSELHO NACIONAL DE TURISMO. Turismo no Brasil 2007 - 2010. Brasília, Junho/2006.

ORGANIZAÇÃO MUNDIAL DE TURISMO. Turismo internacional - uma perspectiva global. 2. ed. Porto Alegre: Bookmann, 2003.

ORGANIZACIÓN MUNDIAL DEL TURISMO. Introducción al turismo. Madrid: Egraf, Junho, 1998.

SANOVICZ, Eduardo. Proxima Estació Plaça Catalunya. 2001. Tese (Doutorado em Turismo) - Departamento de Publicidade, Relações Públicas e Turismo da Escola de Comunicações e Artes, Universidade de São Paulo, São Paulo.

Referência em meio eletrônico

BRASIL 500 Anos: Obras Raras Relacionadas ao Descobrimento do Brasil. Rio de Janeiro: Divisão de Bibliotecas e Documentação da PUC-Rio. Disponível em:

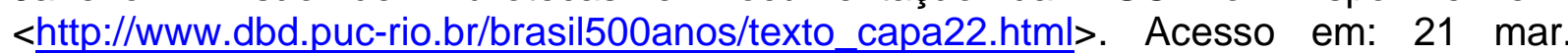
2007. 


\section{APÊNDICE}

\section{APÊNDICE A - Cronograma das Atividades de Pesquisa}

Jan. 2003 - Início do Programa de Trabalho na Embratur.

Jun./Nov. 2003 - Implantação das novas diretrizes.

Jan./Mar. 2004 - Início das avaliações técnicas.

Abr./Set. 2004 - Consolidação dos primeiros resultados.

Set. 2004/Jan. 2005 - Produção dos primeiros textos, coleta de dados e sistematização de informações.

Fev. 2005 - Lançamento do Plano Aquarela.

Mar./Dez. 2005 - Acompanhamento da implantação e dos resultados obtidos pelo Plano Aquarela.

Jan./Jul. 2006 - Revisão Crítica dos Programas, Ajustes e Produção de Documentação e Dados para Análise.

Jul./Nov. 2006 - Consolidação de Dados, Produção dos textos Finais e Apresentação de Tese. 


\section{ANEXOS}

\section{ANEXO A - Depoimentos}

\section{Samira Pavesi, diretora do Recife CVB de 2003 a 2006}

"A partir de 2003, o Brasil se planejou para ser apresentado ao mundo. Foram divididos os produtos, os mercados de atuação, muitos deles ampliados; a atuação e a aproximação junto aos CVB têm sido excelentes. No caso do Recife CVB, essa parceira tem funcionado $100 \%$. Além de estarmos atraindo eventos internacionais, estamos em conjunto com a Embratur fazendo a promoção do nosso destino para os eventos que já foram captados. Isso se reflete diretamente na quantidade de turistas de outros países vindo para Pernambuco".

\section{Jeanine Pires, presidente da Embratur (foi Diretora de Turismo de Negócios e Eventos da Embratur de jan./2003 a ago./2006)}

“A promoção comercial do turismo brasileiro, a partir de 2003, teve um grande impulso com o direcionamento das atribuições da Embratur exclusivamente para a promoção do país no mercado internacional. Com programas de marketing e apoio à comercialização dos nossos destinos, serviços e produtos turísticos no exterior, ampliamos e diversificamos nossa oferta para o estrangeiro, durante décadas calcada apenas em sol e mar e belezas naturais, para segmentos como Ecoturismo, Cultura, Esportes e Negócios e Eventos.

A criação do Plano Aquarela - Marketing Turístico Internacional e da diretoria de Turismo de Negócios e Eventos são os grandes destaques. Enquanto o Plano nos garantiu bases científicas para explorar nossas vantagens estratégicas em 18 mercados, a área de Negócios e Eventos ampliou a participação do Brasil em feiras de 
turismo pelo mundo, elaborou uma agenda de feiras comerciais para promover os nossos eventos e roteiros turísticos e criou uma política de apoio à captação de eventos internacionais para o País.

Tudo isso vem contribuído para alcançar, desde 2003, o trinômio perseguido pela Embratur: mais turistas estrangeiros no país, mais divisas e mais destinos visitados".

\section{José Zuquim, operador e presidente da Braztoa}

"A grande mudança na Embratur foi de conceito e planejamento, com o alvo no mercado internacional. A política de promoção determinou qualificação do Brasil para os compradores do setor e para os consumidores de turismo no planeta como um destino com personalidade, já que fomos vender o país como produto turístico finalmente com marca, com clara definição.

A Braztoa, que no início deste processo não tinha nenhuma operadora com foco neste segmento de mercado, tem hoje mais de 20 operadores com estrutura de receptivo para estrangeiros.

Passamos a ter uma atuação mais abrangente com ações de promoção, comercialização e qualificação e mostramos o Brasil do ponto de vista da segmentação, apresentando nossa diversidade de forma estruturada.

Passou a existir, a partir de então, uma parceria sem precedentes na história do turismo que possibilita, entre outras coisas:

- realizar projetos elaborados a partir da expertise de mercado dessas associações e focados em resultado;

- troca de informações entre mercado e governo colaborando para ajustes de rota de ações e aprimoramento;

- agilidade nos processos e redução de custos, pois a negociação é feita pelo e com o mercado;

- o mercado opera e deixa o governo responsável pelas questões institucionais;

- cooperação e comprometimento de ambas as partes para obtenção de resultados nos planos macro e micro." 
Abel Alves de Castro Júnior, gerente de desenvolvimento da Accor e, de jan./2005 a nov./2006, executivo do Fórum dos Operadores Hoteleiros do Brasil (Fohb)

"O FOHB reconhece grandes e importantes mudanças na Embratur, principalmente na forma de trabalhar com as entidades, envolvendo-as em todos os processos e projetos. No nosso caso, trabalhamos diretamente nos projetos das Caravanas e Press Trip, alem do belíssimo Curso de Economia e Turismo para Jornalistas nas principais capitais do Brasil. Isso agregou valor ao nosso trabalho e trouxe reconhecimento para os projetos do Governo Federal.

Sem dúvida, o resultado já começa a aparecer - como o aumento de turistas internacionais, além de mais dólares entrando no país - mesmo sabendo que ações da Embratur são de longo prazo. É importante, portanto, que elas tenham continuidade e que sempre seja desenvolvidas em parceria com os profissionais do mercado."

\section{Paulo Senise, diretor do Rio CVB}

"O Plano Aquarela possibilitou a organização da oferta em linhas bem definidas de produtos turísticos, com melhor atendimento às demandas específicas por parte da equipe da Embratur.

A disciplina adotada pela Embratur para distribuição da verba descentralizada possibilitou a muitos CVBs a execução de eventos promocionais que potencializaram a promoção do Brasil para segmentos específicos. O programa de seminários no exterior é uma boa idéia que deve ser aperfeiçoada, respeitando as exigências culturais de cada mercado." 


\section{Roberto Dultra, diretor da Braztoa}

"A criação do Mtur e a especificação do foco da Embratur na promoção dos destinos e produtos turísticos brasileiros no exterior foram extremamente positivas para o país, promovendo condições para colocar a indústria do turismo no Brasil em evidência. As mudanças foram claras, a começar pelo planejamento, seguido de estabelecimento de metas a serem alcançadas e um sério trabalho desenvolvido para atingir tais objetivos.

O Turismo sempre foi uma atividade secundária no Brasil, o que é estranhamente contraditório, uma vez que o nosso país pode ser considerado o de maior diversidade em produtos e destinos do mundo, além de não termos problemas que outros destinos em evidência no setor têm, como terrorismo e catástrofes naturais. Temos problemas sérios, entre eles a questão da segurança pública que se apresenta precária e cada vez mais preocupante para nosso segmento. Porém, mais de $90 \%$ dos turistas estrangeiros que vêm ao Brasil demonstram o interesse em voltar. Constatação do descaso com o Turismo é o fato de não termos tido até 2002, um ministério exclusivo para o setor e quando criado, alcançamos notoriedade, crescimento acentuado e o principal: caminhamos a passos largos para a profissionalização do setor, condição imprescindível não apenas para o crescimento, mas principalmente para a sustentação do mesmo.

Muito ainda há por ser feito, principalmente no que concerne a investimentos em divulgação e propaganda do Brasil no exterior, porém o processo está iniciado e com bases sólidas.

Os resultados desse trabalho devem ser medidos com pesquisas sérias, que apresentem à indústria e ao governo estatísticas que reflitam com credibilidade o desenvolvimento da indústria. Até 2002, não tínhamos um mapeamento do setor, hoje já contamos com pesquisas que demonstram o crescimento alcançado a partir do trabalho desenvolvido pela Embratur em parceria com a iniciativa privada.

É importante ressalvar que o crescimento no número de turistas não quer dizer que as empresas estejam no mesmo ritmo. Temos problemas sérios que afetam diretamente o turismo receptivo internacional, entre eles a questão cambial. A cotação 
em dólar prejudica o setor, uma vez que com a desvalorização da moeda americana e a impossibilidade de aumentarmos as tarifas de forma a cobrir esse déficit, as empresas principalmente operadoras e hotéis - vivem um momento contraditório e complicado face ao crescimento de turistas registrado.

A precariedade da malha aérea também dificulta as operações e o crescimento. A crise da Varig, seguida do caos instaurado após a queda do avião da Gol, que ocasionou a crise dos controladores de vôos, trouxeram conseqüências drásticas para o receptivo internacional, pois temos grande demanda, porém pouca oferta de vôos, além dos atrasos que prejudicam a imagem do país.

Sem dúvida a união das iniciativas pública e privada é de extrema importância e segue um formato que está dando certo. A integração entre as entidades do setor e o governo é fundamental, posto que as entidades representam as empresas responsáveis por todas as etapas da operação do turismo e a Embratur propicia, através do Plano Aquarela de promoção e marketing, as condições básicas para as ações de vendas do setor nos principais mercados emissores internacionais. Seria inviável a realização de um trabalho de sucesso sem essa parceria.

Dois programas, para nós, têm apresentado resultados muito positivos: o Caravana Brasil, que possibilita ao agente de viagens do exterior conhecer os destinos in loco, abrindo uma série de possibilidades de promoção. É impossível vender um produto que se conhece apenas na teoria. As visitas de familiarização geram credibilidade em quem está vendendo por propiciar o conhecimento da infra-estrutura local, os produtos turísticos, a capacitação profissional de quem recepciona, entre outros fatores importantes. O segundo programa é o de promoção no exterior através de participação em feiras internacionais e dos seminários promovidos no exterior sobre - Brasil, apresentando aos agentes de viagens dos principais mercados emissores internacionais a diversidade de destinos e produtos que temos a oferecer." 


\section{Anexo B - Documento da Embratur sobre os bidding books}

\section{Bidding Book}

Modelo completo para a confecção de um bidding book

A EMBRATUR, por meio de sua Diretoria de Turismo de Negócios e Eventos/Gerência de Turismo de Eventos, apóia entidades brasileiras a candidatarem- se a sediar eventos internacionais no Brasil.

Dentre as diversas formas de apoio, a EMBRATUR, em parceria com a entiadade e a autoridade de turismo local e/ ou o Convention Bureau local, prepara o dossiê de candidatura (Bidding Book).

\section{OBSERVAÇÕES IMPORTANTES !!!!}

- Todo o material deve ser fornecido para a EMBRATUR em Língua Inglesa ou Língua Espanhola, de acordo com o que for acertado previamente. Caso contrário, será descartado.

- As fotos devem ser enviadas em alta resolução (mínimo 300 d.p.i.)

- As figuras e mapas devem estar na extensão JPG.

\section{Estrutura completa do bidding book}

A primeira página do bidding deve constar o nome e a edição do evento ao qual a candidatura refere-se, além do ano em que acontecerá o evento para o qual está candidatando-se. Também deve constar o nome da cidade candidata, estado e país.

Na seqüência, teremos 7 (sete) lâminas divisórias, as quais organizarão o 
book que será dividido da seguinte forma:

1. Projeto do Evento

- Responsabilidade: Entidade Proponente

Sobre a proposta, devem ser contempladas as seguintes informações, quando solicitadas ou quando disponíveis facilmente:

- Uma carta (até 2 páginas) da entidade proponente com a apresentação de argumentações e justificativas para a candidatura brasileira. Muitas entidades internacionais têm como um dos seus objetivos principais, a disseminação de conhecimento nos países que a compõe. Por esta razão, caso o evento nunca tenha sido realizado no Brasil e/ou na América do Sul ou Latina, isso deve ser ressaltado, pois é um argumento forte e, ainda, a realização de um evento no Brasil pode significar uma oportunidade de expansão da entidade no continente sul- americano e/ou no país. Tal carta deve ser dirigida ao presidente da entidade superior (a entidade internacional, por exemplo).

- A carta deve ser em papel timbrado, ser assinada e, se possível, deverá ser inserida uma foto de quem assina. A carta deve ser "escaneada" e enviada em formato .jpg

- Sugestão de comissão organizadora: além da parte operacional, inserir no comitê organizador o nome de personalidades de destaque na área (ainda que em cargos honorários);

- Sugestão de tema e sub- temas (ainda que genéricos);

- Sugestão de programação;

- Sugestão de alguns palestrantes (se possível);

- Sugestão de valores de inscrição (quando exigido pela entidade internacional). Muitas entidades praticam valores de inscrição inferiores para participantes provenientes de países em desenvolvimento, como forma de democratização do acesso aos eventos;

- Detalhamento financeiro: informar somente se solicitado pela entidade internacional em seus guidelines;

- Plano de promoção caso o evento seja captado: informar somente se solicitado pela entidade internacional em seus guidelines. 
2. Cartas de apoio à candidatura

- Responsabilidades compartilhadas

As seguintes cartas de apoio devem ser providenciadas:

- Órgãos do Governo Federal (responsabilidade da EMBRATUR);

- Órgãos dos Governos Estadual e Municipal (responsabilidade do Convention \& Visitors Bureau local);

- Empresas e/ou Entidades ligadas ao setor de atuação da entidade proponente no Brasil e no exterior. Se forem obtidas cartas de outros países, poderemos reforçar a candidatura brasileira tratando- a como uma candidatura sul-americana ou latino-americana (responsabilidade da entidade proponente).

3. Apresentação da entidade proponente

- Responsabilidade: Entidade Proponente

Sobre a entidade proponente, deverão ser contemplados dados objetivos, como:

- Histórico, tempo de existência, tradição e importância científica, política e econômica da entidade para o país;

- O desenvolvimento do segmento no país;

- Abrangência territorial no país, número de associados, representatividade;

- Demonstrar qual seria o potencial de participantes brasileiros e/ou sulamericanos no evento exemplificando com números de congressos já realizados (data, edições, número de participantes, metragem de exposição e resultados). Isso interessa muito para a entidade internacional;

- Infra- estrutura, sede, recursos;

- Atividades desenvolvidas pela entidade;

- Personalidades de destaque que estejam ligadas à entidade brasileira, em especial aquelas reconhecidas ou envolvidas com a entidade promotora internacional; 
- Diferenciais (envolvimento social e acadêmico, por exemplo);

- Contatos da entidade proponente: nomes, cargos, endereços, telefone, endereço eletrônico e website.

4. Apresentação do Brasil

- Responsabilidade: EMBRATUR

Uma candidatura em nível internacional é, antes de qualquer coisa, uma candidatura brasileira! Por esta razão deve- se fazer uma apresentação do país em linhas gerais. Os seguintes itens devem ser contemplados:

- Informações Geográficas / Aspectos de Geografia Física

- Aspecto Sócio- Político

- Aspectos Culturais

- Aspectos Econômicos

- O Brasil como destino para eventos internacionais

- Destaques no esporte (somente para captação de eventos esportivos)

- Informações úteis: vistos, moeda, fuso horário, idioma, gorjetas, etc.

5. Apresentação do destino (cidade ou resort)

Responsabilidade: escritório de turismo local (Convention \& Visitors Bureau e/ou Secretaria de Turismo)

Deve- se apresentar toda a estrutura da cidade focada para o Turismo de eventos. Os seguintes itens devem ser contemplados:

- Mapa localizando e destacando a cidade dentro do país (neste mapa devem constar também as principais cidades do país);

- Clima - inserir um gráfico com as temperaturas médias durante o ano;

- Caso a cidade candidata receba vôos internacionais DIRETOS SEM CONEXÃO, deve- se expor tal informação em forma de tabela, informando os principais fluxos internacionais e tempo de vôo. Caso não receba (ou receba em pouca quantidade), deve-se mencionar os vôos até os 
principais portões de entrada: Rio de Janeiro, Salvador e/ ou São Paulo e o tempo de vôo e fluxo entre estas cidades e a cidade candidata.

- Informações e fotos do aeroporto.

- Mapa esquemático (turístico) da cidade mostrando o aeroporto, o centro de convenções, a rede hoteleira e demais pontos de interesse. Tabela de distância (exemplo: centro de convenções proposto com relação ao aeroporto e rede hoteleira);

- Transporte coletivo (para eventos populares) e/ou mencionar custo de táxi (preço médio de corridas entre rede hoteleira e centro de eventos indicado) e frotas disponíveis;

- Descritivo do Centro de Convenções:

- capacidade das salas em diferentes formatos;

- capacidade do teatro ou auditório principal e infra-estrutura (sonorização, iluminação, cabines, palco, camarins);

- plantas, se possível também em 3D (não enviar em autocad)

- área disponível para exposição (carga e descarga, pé direito e climatização);

- infra- estrutura complementar: banheiros, bilheterias, segurança, estacionamento, área e opções de alimentação, business center, acesso para deficientes, ambulatório, correios, etc...

- fotos em JPEG (alta resolução - mínimo 300 d.p.i.);

- Rede hoteleira

- quantidade de leitos (de opções mais baratas até hotéis e resorts de luxo);

- referência média de preço;

- mencionar redes internacionais;

- Restaurantes: destacar a culinária local e a disponibilidade de cozinha internacional (texto com no máximo 10 linhas) - fotos de pratos (alta resolução - mínimo 300 d.p.i..);

- Estrutura de serviços: rede bancária e lojas de câmbio, shopping centers, ruas comerciais e opções de vida noturna;

- Opções de atividades e passeios para acompanhantes durante o período do evento na cidade e redondezas. Pontos turísticos, fotos ;

- Universidades - destaques na produção do saber (no máximo 10 linhas de texto); 
- Consulados e embaixadas (apenas mencionar a existência e os países);

- Diferenciais da cidade: títulos e distinções (somente títulos reconhecidos e mencionar a fonte da informação);

- Listar os eventos mais importantes que já aconteceram na cidade (mais expressivos, mais complexos, maiores e internacionais), num máximo de 10 eventos. Citar nome, número de participantes, data (contemplar somente os últimos 5 anos);

- Depoimentos de representantes de entidades internacionais e/ou nacionais a respeito do destino (até 5 depoimentos);

6. Opções de viagens pré e pós evento

- Responsabilidade: EMBRATUR

Serão apresentados os seguintes produtos, os quais a EMBRATUR utiliza- se para a promoção do turismo brasileiro no exterior:

- Sol e Mar

- Cultura

- Esportes

- Ecoturismo

7. Contatos e Fontes de Informação

- Responsabilidades compartilhadas

Inserir a informação de que o bidding book foi fruto de um trabalho conjunto entre:

- Entidade

- Governo do Brasil/Ministério do Turismo/EMBRATUR

- Entidade de Turismo local: CVB e/ou Secretaria de Turismo

- Alguma empresa que possa ter ajudado. Exemplo: uma empresa organizadora de eventos, um centro de convenções, uma agência de turismo, entre outras 
Deve constar nome completo, endereço, telefone, email, site e uma pessoa de contato. Uma lista com sites úteis (além daqueles já mencionados) também deve ser incluída.

8. Compilamento das informações, revisão do texto e impressão

- Responsabilidade: EMBRATUR

A EMBRATUR irá compilar toda a informação fornecida pela entidade e pelo escritório de turismo local. Da mesma forma irá fazer a revisão do texto e trabalhar o conceito visual, por meio de sua agência de publicidade. 
This document was created with Win2PDF available at http://www.daneprairie.com. The unregistered version of Win2PDF is for evaluation or non-commercial use only. 